\title{
Methane and nitrous oxide distributions across the North American Arctic Ocean during summer, 2015
}

\author{
by \\ Lindsay Alexandra Fenwick \\ B.Sc. (Hons) Queen's University, 2013 \\ A THESIS SUBMITTED IN PARTIAL FULFILLMENT \\ OF THE REQUIREMENTS FOR THE DEGREE OF \\ Master of Science \\ in \\ The Faculty of Graduate and Postdoctoral Studies \\ (Oceanography)
}

The University of British Columbia

(Vancouver)

July 2016

(C) Lindsay Alexandra Fenwick, 2016 


\section{Abstract}

We collected Arctic Ocean water column samples for methane $\left(\mathrm{CH}_{4}\right)$ and nitrous oxide $\left(\mathrm{N}_{2} \mathrm{O}\right)$ analysis on three separate cruises in the summer and fall of 2015, covering a $\sim 10,000 \mathrm{~km}$ transect from the Bering Sea to Baffin Bay. Our sampling program provides a large-scale, three-dimensional view of methane and nitrous oxide concentrations across contrasting hydrographic environments, from the deep oligotrophic waters of the deep Canada Basin and Baffin Bay, to the productive continental shelf regions of the Bering and Chukchi Shelves. Percent saturation relative to atmospheric equilibrium ranged from 30$800 \%$ and $75-145 \%$ for $\mathrm{CH}_{4}$ and $\mathrm{N}_{2} \mathrm{O}$, respectively, with the highest concentrations of both gases occurring in waters overlying the continental shelf in the northern Chukchi Sea. Nitrification and denitrification in the sediments of the Bering and Chukchi Shelves constituted a major source of $\mathrm{N}_{2} \mathrm{O}$ to the water column, and the resulting high $\mathrm{N}_{2} \mathrm{O}$ concentrations were transported across the entire North American Arctic. Methane sources to the water column were more spatially heterogeneous, reflecting a greater variety of hydrographic influences, including likely inputs from sediments, rivers, and sea ice processes. Localized regions of high $\mathrm{CH}_{4}$ concentrations were observed at various locations across our sampling transect, but unlike $\mathrm{N}_{2} \mathrm{O}, \mathrm{CH}_{4}$ was rapidly consumed through microbial oxidation, as shown by the ${ }^{13} \mathrm{C}$ enrichment of $\mathrm{CH}_{4}$ at low concentrations. High $\mathrm{CH}_{4}$ signatures were thus more localized across our sampling region. For both $\mathrm{CH}_{4}$ and $\mathrm{N}_{2} \mathrm{O}$, surface super-saturation and sea-air fluxes were generally low across the region, with valuess of $1.3 \pm 1.2 \mu \mathrm{mol} \mathrm{m}^{-2} \mathrm{~d}^{-1}$ and $-0.52 \pm 1.0 \mu \mathrm{mol} \mathrm{m}^{-2} \mathrm{~d}^{-1}$, for $\mathrm{CH}_{4}$ and $\mathrm{N}_{2} \mathrm{O}$, respectively. Low surface water concentrations were at least partially attributable to dilution by low $\mathrm{CH}_{4}$ and $\mathrm{N}_{2} \mathrm{O}$ fresh water. Our results provide insight into the factors controlling the distribution of $\mathrm{CH}_{4}$ and $\mathrm{N}_{2} \mathrm{O}$ in the North American Arctic Ocean, and an important baseline data set against which future changes can be assessed. 


\section{Preface}

This dissertation is based on a concept formed by my supervisor (Dr. Philippe Tortell) and myself. Fieldwork and sample collection was done by me, Dr. Tortell, and Department of Fisheries and Oceans scientists, Sarah Zimmermann and Bill Williams. Nutrient samples and CTD data for SWL 2015-09 and LSSL 2015-09 were collected and analyzed by the Institute of Ocean Sciences. Ammonium samples for SWL 2015-09 were collected by Lee Cooper and analyzed by the Nutrient Analytical Services Laboratory at the University of Maryland. Nutrient samples for ArcticNet 1502 were collected and analyzed by the research group of Jean Eric Tremblay (Université Laval). Ellen Damm (Alfred Wegner Institute, Bremerhaven, Germany) analyzed the $\partial^{13} \mathrm{C}_{\mathrm{CH} 4}$ samples and helped interpret the data. I was responsible for the analysis of $\mathrm{CH}_{4}$ and $\mathrm{N}_{2} \mathrm{O}$ samples using GC-MS, interpretation of data, and writing of the dissertation. Dr. Tortell thoroughly edited the thesis, provided advice and ideas, and helped interpret data. David Capelle, Ellen Damm, Kristina Brown, and Svein Vagle contributed valuable edits. A version of this thesis will be submitted as a manuscript with co-authors Philippe Tortell, David Capelle, Ellen Damm, Svein Vagle, Bill Williams, and Sarah Zimmermann. 


\section{Table of Contents}

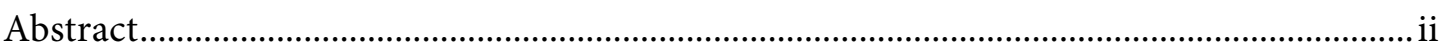

Preface

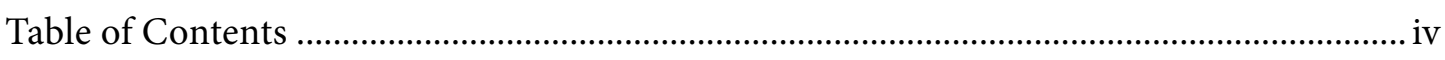

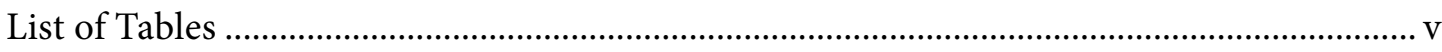

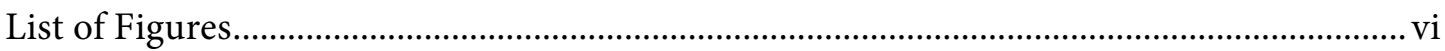

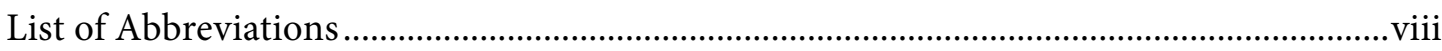

Acknowledgements ........................................................................................................... ix

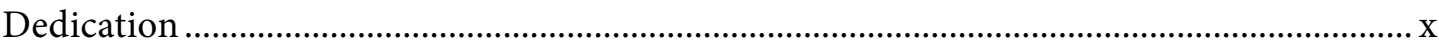

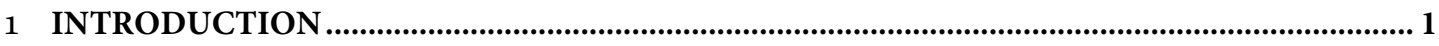

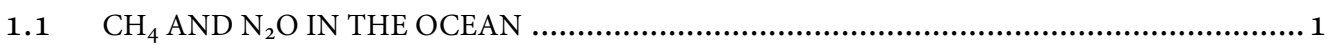

$1.2 \mathrm{CH}_{4} \mathrm{AND} \mathrm{N}_{2} \mathrm{O}$ IN THE ARCTIC OCEAN ………................................................... 4

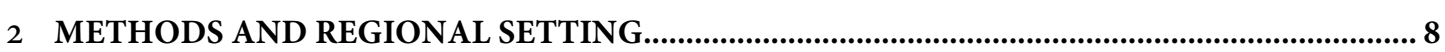

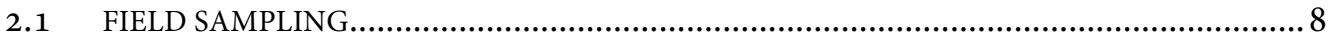

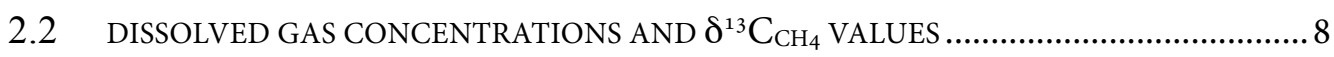

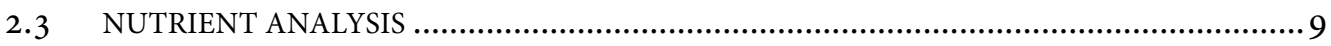

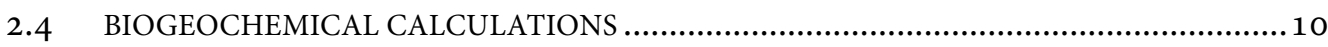

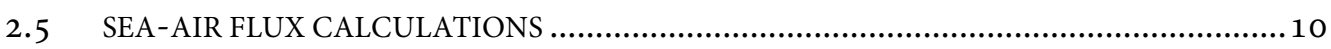

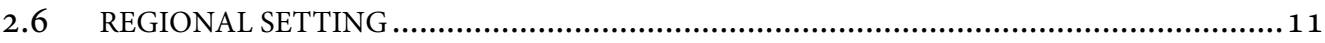

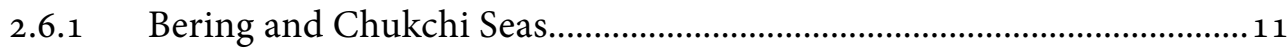

2.6.2 Canada Basin and Beaufort Sea................................................................. 13

2.6.3 Canadian Arctic Archipelago ...................................................................... 14

2.6.4 Seafloor methane sources.......................................................................... 14

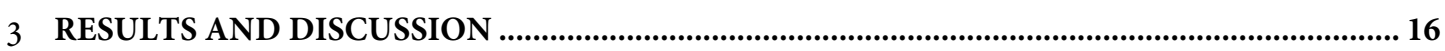

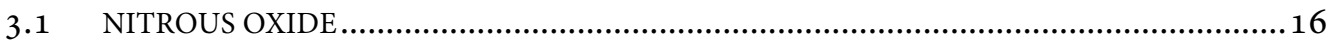

3.1.1 $\quad \mathrm{N}_{2} \mathrm{O}$ in the Bering and Chukchi Seas........................................................ 18

3.1.2 $\quad \mathrm{N}_{2} \mathrm{O}$ in the Canada Basin and Beaufort Sea..............................................2

3.1.3 $\quad \mathrm{N}_{2} \mathrm{O}$ in the Canadian Arctic Archipelago ..............................................26

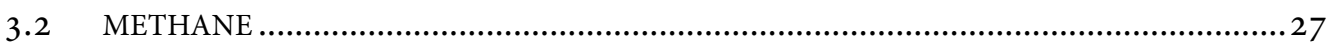

3.2.1 $\mathrm{CH}_{4}$ in the Bering and Chukchi Seas.......................................................2 28

3.2.2 $\mathrm{CH}_{4}$ in the Canada Basin and Beaufort Sea ...............................................33

3.2.3 $\mathrm{CH}_{4}$ in the Canadian Arctic Archipelago................................................... 36

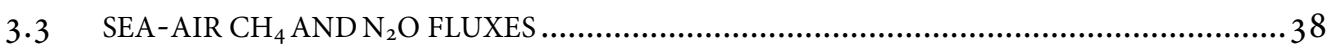

4 CONCLUSIONS

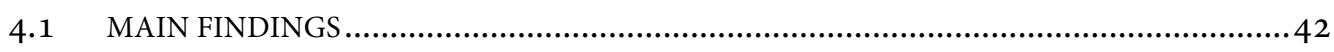

4.2 CAVEATS AND LIMITATIONS ………….............................................................. 43

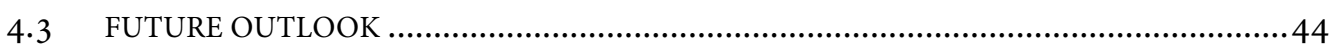

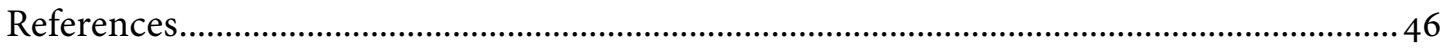




\section{List of Tables}

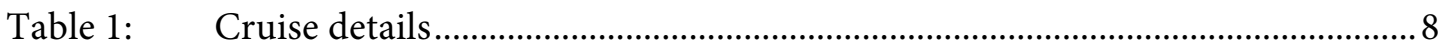

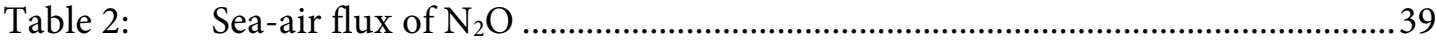

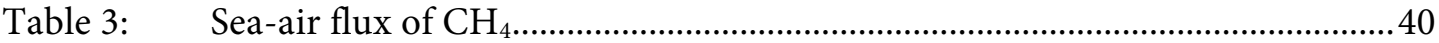

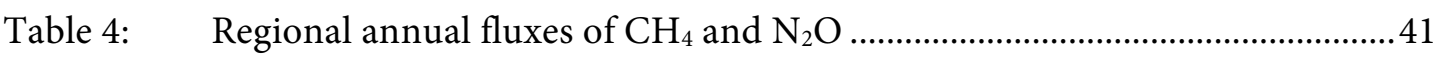




\section{List of Figures}

Figure 1: Map of study area, showing the locations of depth profiles (yellow circles) and dominant Pacific Water boundary currents. The black line denotes the transect along which the contour plots (Figure 5 and Figure 10) were derived. Based on [Macdonald et al., 2004] . .7

Figure 2: Salinity vs. temperature plot showing the different water masses observed in the North American Arctic. The top panel shows percent saturation of $\mathrm{N}_{2} \mathrm{O}$, while the bottom panel shows percent saturation of $\mathrm{CH}_{4}$. Circles, squares, and triangles denote measurements from the Bering and Chukchi Seas, Canada Basin, and Canadian Arctic Archipelago, respectively

Figure 3: Density vs. concentration plots averaged by sub-region. The grey shaded area is the standard deviation of the mean. .18

Figure 4: Map and corresponding $\mathrm{N}_{2} \mathrm{O}$ depth profiles in the Bering and Chukchi Seas. Black filled circles denote a measurement, while the error bars represent the standard deviation of the duplicate samples. The grey dotted line is the atmospheric equilibrium concentration. 20

Figure 5: Nitrous oxide and density contour plots. The top two panels show the distribution of $\mathrm{N}_{2} \mathrm{O}$ and density along a $\sim 1500 \mathrm{~km}$ transect from the Bering to the Beaufort Sea (black line on Fig. 1), respectively. The bottom panel shows the mean concentration of $\mathrm{N}_{2} \mathrm{O}$ on the 26.5 density surface, illustrating the accumulation of $\mathrm{N}_{2} \mathrm{O}$ along this isopycnal.

Figure 6: $\Delta \mathrm{N}_{2} \mathrm{O}$ vs. AOU and $\mathrm{N}^{\star}$ plots, broken down by sub-region. Only the Canada Basin UHL is shown in order to better compare the properties of the Pacific water masses between regions. Trend lines are shown where there is a statistically significant regression model $(\mathrm{p}<0.05)$.

Figure 7: Map and $\mathrm{N}_{2} \mathrm{O}$ depth profiles in the Canada Basin and Beaufort Sea...................24

Figure 8: Map and depth profiles of $\mathrm{N}_{2} \mathrm{O}$ in the CAA. ..........................................................2

Figure 9: Map and depth profiles of $\mathrm{CH}_{4}$ in the Bering and Chukchi Seas...........................29 
Figure 10: Methane and density contour plots. The top panel shows the distribution of $\mathrm{CH}_{4}$ along a $\sim 1500 \mathrm{~km}$ transect from the Bering to the Beaufort Sea (black line on Fig. 1). The bottom panel shows the density distribution along the same transect.................30

Figure 11: Oxidation curve calculated using a Rayleigh distillation model with an initial concentration of $31 \mathrm{nmol} / \mathrm{L}$, a $\partial^{13} \mathrm{C}_{\mathrm{CH} 4}$ value of $-40 \%$ o $\mathrm{VPDB}$, and an isotopic fractionation factor of 1.002 .

Figure 12: Map and depth profiles of $\mathrm{CH}_{4}$ concentrations in the Canada Basin and Beaufort Sea 33

Figure 13: This is a representative depth profile of $\mathrm{CH}_{4}$ and fluorescence, showing the cooccurrence of the $\mathrm{CH}_{4}$ and chlorophyll maxima. Filled black circles denote $\mathrm{CH}_{4}$ concentration and error bars represent the standard deviation of the duplicates. The dotted line is fluorescence. 34

Figure 14: Map and depth profiles of $\mathrm{CH}_{4}$ concentrations in the CAA and Baffin Bay.....37 Figure 15: $\mathrm{CH}_{4}$ vs. salinity scatter plot of all samples collected in the CAA and Baffin Bay 


\section{List of Abbreviations}

$\begin{array}{ll}\text { ACW } & \text { Alaska Coastal Water } \\ \text { AOU } & \text { Apparent oxygen utilization } \\ \text { BSW } & \text { Atlantic Water } \\ \text { CAA } & \text { Bering Sea Water } \\ \mathrm{CH}_{4} & \text { Canadian Arctic Archipelago } \\ \mathrm{N}_{2} \mathrm{O} & \text { Nitrous oxide } \\ \mathrm{NH}_{4}{ }^{+} & \text {Ammonium } \\ \mathrm{NO}_{3}{ }^{-} & \text {Nitrate } \\ \mathrm{NO}_{2}{ }^{-} & \text {Nitrite } \\ \mathrm{O}_{2} & \text { Oxygen } \\ \mathrm{PML}^{-} & \text {Polar Mixed Layer } \\ \mathrm{PSW}^{\mathrm{PW}} & \text { Pacific Summer Water } \\ \mathrm{PWW}^{\mathrm{UHL}} & \text { Pacific Water } \\ & \text { Pacific Winter Water } \\ & \text { Upper Halocline Layer }\end{array}$




\section{Acknowledgements}

I have been fortunate to be supported by many wonderful individuals without whom this thesis would not have been possible. First and foremost, I would like to thank my supervisor, Philippe Tortell, for his unwavering encouragement, enthusiasm, and ability to thoroughly edit a 10,000-word manuscript sent at midnight by 6am the next morning. Thank you for the initiation into the world of oceanography. I would also like to thank David Capelle for his ridiculous accents, incredible patience, and calm demeanor while being informed that the instrument is no longer working, yet again. No number of washed bottles will ever begin to repay you. I am also very appreciative of the insightful editing by Ellen Damm and Kristina Brown, without which this thesis would not be nearly as strong. Thank you to Kristin Orians and Roger François for their revisions of this thesis.

The dissolved gases in this thesis would still be in the ocean had it not been for the captains and crews of the CCGS Sir Wilfrid Laurier, CCGS Louis St. Laurent, CCGS Amundsen, and CCGS John P. Tully, and the scientists at IOS. Thank you in particular to Dr. Svein Vagle, for his can-do attitude and enthusiasm for this project, and Sarah Zimmermann and Bill Williams for their dedication and insights into Arctic hydrography. Thank you to the Grebmeier group, Jennifer Long, and Curtis Martin for their camaraderie in the Arctic and musical puppet show talents, and Bruce Patterson, for helping me protect my egg.

I am indebted for the friendship, insight, and caring of the Tornado lab, my officemates, and many others at UBC. Lian, Kang, Joanne, Dave, Nina, Tereza, Ania, Anna, Alysia, Robert, Will, Manuel, Lucy, Michael, Brett, and Kirsten- I will miss you all.

None of this would have been possible without my family. My parents have always been supportive of my every interest and encouraged me to collect data- of any kind. My grandparents have been a source of inspiration, and their relentless support of education has lead to my achievement of the same lever of education as my Grandpa.

And D.J., my best friend and teammate- I learn from you every day. I could not have done this without your love and emotional support. Thank you. 
for Elaine and Don 


\section{Introduction}

After carbon dioxide, methane $\left(\mathrm{CH}_{4}\right)$ and nitrous oxide $\left(\mathrm{N}_{2} \mathrm{O}\right)$ are the two greenhouse gases that have most influenced climate warming over the past 250 years [IPCC, 2013]. While atmospheric concentrations of $\mathrm{CH}_{4}$ and $\mathrm{N}_{2} \mathrm{O}$ have been relatively stable for the past 12,000 years, transitions from glacial to interglacial climates have previously been accompanied by large atmospheric increases in both of these gases. More recently, the atmospheric concentrations of these gases have increased by $165 \%$ and $20 \%$, respectively, since preindustrial times, as a result of various anthropogenic activities. The current values (1910 and $328 \mathrm{ppb}$ for $\mathrm{CH}_{4}$ and $\mathrm{N}_{2} \mathrm{O}$, respectively) have no precedent in the past 800,000 years (Data provided by NOAA ESRL Global Monitoring Division, Boulder, Colorado, USA; http://esrl.noaa.gov/gmd/) [Schilt et al., 2010]. Although the contribution of $\mathrm{CH}_{4}$ and $\mathrm{N}_{2} \mathrm{O}$ to radiative forcing in the atmosphere is clear, the cycling of these gases among various global reservoirs is still relatively poorly understood. Understanding the global budget and cycling of $\mathrm{CH}_{4}$ and $\mathrm{N}_{2} \mathrm{O}$ is a primary research objective in the Earth Sciences.

\section{$1.1 \quad \mathrm{CH}_{4}$ AND $\mathrm{N}_{2} \mathrm{O}$ IN THE OCEAN}

The ocean plays a key role in the global cycles of greenhouse gases, including $\mathrm{N}_{2} \mathrm{O}$, and to a lesser extent, $\mathrm{CH}_{4}$. Surface ocean waters are estimated to account for $\sim 2$ and 20-60\% of the total emissions of $\mathrm{CH}_{4}$ and $\mathrm{N}_{2} \mathrm{O}$ to the atmosphere, respectively, resulting from a series of complex production and consumption processes [Reeburgh, 2007; IPCC, 2013]. A variety of biologically-mediated processes produce and consume $\mathrm{CH}_{4}$ and $\mathrm{N}_{2} \mathrm{O}$ within the ocean and the sediments that lie underneath. Depending on environmental conditions, the ocean can be a net source or sink of these gases. 
$\mathrm{N}_{2} \mathrm{O}$ cycling in the marine environment is controlled by two processes: nitrification and denitrification. The former, which is thought to be the dominant source of oceanic $\mathrm{N}_{2} \mathrm{O}$, is completed in two steps. The first, carried out by ammonia-oxidizing bacteria, oxidizes ammonium $\left(\mathrm{NH}_{4}^{+}\right)$to $\mathrm{NO}_{2}^{-}$. The decomposition of $\mathrm{NH}_{2} \mathrm{OH}$, an intermediate in the oxidation of $\mathrm{NH}_{3}$ to $\mathrm{NO}_{2}^{-}$, produces $\mathrm{N}_{2} \mathrm{O}$ as a by-product. The second step, performed by nitrite-oxidizing bacteria, oxidizes $\mathrm{NO}_{2}{ }^{-}$to $\mathrm{NO}_{3}{ }^{-}$. Although nitrification is an aerobic process, $\mathrm{N}_{2} \mathrm{O}$ yields are enhanced under low oxygen conditions. This is thought to be because of the "nitrifier-denitrification" process, or the tendency of nitrifiers to reduce $\mathrm{NO}_{2}{ }^{-}$to $\mathrm{N}_{2} \mathrm{O}$ when they are $\mathrm{O}_{2}$-limited [Codispoti et al., 2005]. Denitrification is another key process in the $\mathrm{N}_{2} \mathrm{O}$ cycle. This pathway is limited to suboxic to anoxic conditions, and reduces fixed nitrogen $\left(\mathrm{NO}_{3}{ }^{-}\right)$to nitrogen gas $\left(\mathrm{N}_{2}\right)$, producing $\mathrm{N}_{2} \mathrm{O}$ as an intermediate. At oxygen concentrations near the upper limit for denitrification, $\mathrm{N}_{2} \mathrm{O}$ is mostly released, resulting in a net production of $\mathrm{N}_{2} \mathrm{O}$ [Codispoti et al., 2005]. Under low oxygen conditions, however, well-established denitrification systems proceed to completion, resulting in the biological consumption of $\mathrm{N}_{2} \mathrm{O}$. The highest production of $\mathrm{N}_{2} \mathrm{O}$ occurs at the boundaries of oxygen minimum zones, where nitrification and incomplete denitrification occur simultaneously, yielding elevated $\mathrm{N}_{2} \mathrm{O}$ concentrations [Codispoti et al., 2005].

Sources of $\mathrm{CH}_{4}$ to the ocean are varied, including inputs from gas hydrates (frozen $\mathrm{CH}_{4}$ structures), abiotic serpentinization at mid-ocean ridges, and seepage from hydrocarbon deposits [Reeburgh, 2007]. The majority of $\mathrm{CH}_{4}$ in the ocean likely is produced though sedimentary methanogenesis, during the anaerobic breakdown of organic matter [Reeburgh, 2007], and subsequent diffusion into the water column. Additional sources of $\mathrm{CH}_{4}$ may come from freshwater runoff from regions with anaerobic sediments. Despite relatively large contributions from these sources, the $\mathrm{CH}_{4}$ concentrations in much of the ocean remain below atmospheric saturation due to intense aerobic and anaerobic microbial oxidation in both the sediments and the water column. However, somewhat paradoxically, the well-oxygenated surface layer of the ocean sometimes contains a $\mathrm{CH}_{4}$ maximum. Several hypotheses have been proposed to explain this enigma, including $\mathrm{CH}_{4}$ production in the anoxic microenvironments such as the guts of zooplankton or within sinking particles [eg., Oremland, 1979; De Angelis and Lee, 1994; Karl and Tilbrook, 1994], the cleavage of methylated substrates by bacteria or phytoplankton [Karl et al., 2008; 
Damm et al., 2010], and advection from regions with hydrocarbon seeps or destabilized gas hydrates [Naqvi et al., 2010 and references therein]. The cause(s) of this apparent 'methane paradox' remain poorly understood.

Kinetic isotope effects resulting from the production and oxidation of $\mathrm{CH}_{4}$ impart a signature on the stable isotopic composition of $\mathrm{CH}_{4}$ which can be used to discern between different $\mathrm{CH}_{4}$ sources and differentiate between the operation of distinct processes [Reeburgh, 2007]. $\mathrm{CH}_{4}$ from biogenic sources tends to have a $\partial^{13} \mathrm{C}_{\mathrm{CH} 4}$ value of $<-50 \%$ VPDB, while $\mathrm{CH}_{4}$ of thermogenic origin has a $\partial^{13} \mathrm{C}_{\mathrm{CH}}$ value of $>-50 \%$ [Whiticar, 1999]. As light $\mathrm{CH}_{4}$ is preferentially oxidized by microbes, the $\mathrm{CH}_{4}$ pool becomes increasing heavy as it is exposed to oxidative processes. This property can therefore be used to determine whether a decreasing $\mathrm{CH}_{4}$ concentration is due to mixing or dilution, or due to biological oxidation [Reeburgh,2007]. Previous studies have used this to determine the flow paths of $\mathrm{CH}_{4}$, understand $\mathrm{CH}_{4}$ cycling in ice-surrounded open areas, and identify recently biologically-produced $\mathrm{CH}_{4}$ in the surface ocean [Damm et al., 2005, 2007, 2008; Sasakawa et al., 2008].

Among the various environmental conditions influencing $\mathrm{CH}_{4}$ and $\mathrm{N}_{2} \mathrm{O}$ cycling, oxygen concentrations are particularly important. As discussed above, low oxygen concentrations favour the production of both gases. Continental shelf seas, particularly those where low oxygen waters are exposed to the surface layers, or those that are underlain by low oxygen sediments, can release large quantities of $\mathrm{CH}_{4}$ and $\mathrm{N}_{2} \mathrm{O}$ to the atmosphere [Nevison et al., 2004; Naqvi et al., 2010]. Major marine oxygen-deficient zones in upwelling systems, such as those off Peru and Chile and in the Arabian Sea, have been linked to high sea-air fluxes of $\mathrm{CH}_{4}$ and $\mathrm{N}_{2} \mathrm{O}$ [Bange et al., 1998; Farías et al., 2009]. The Peruvian upwelling system has been shown to contain some of the highest near-surface $\mathrm{N}_{2} \mathrm{O}$ concentrations in the world, while measured sea-air fluxes of $\mathrm{CH}_{4}$ on the Chilean margin range up to $59 \mu \mathrm{mol} \mathrm{m}^{-2} \mathrm{~d}^{-1}$ [Naqvi et al., 2010 and references therein]. In addition, regimes with abundant supplies of organic matter to the sediments, such as over the Namibian and Indian continental shelves, contain some of the highest near-surface $\mathrm{CH}_{4}$ and $\mathrm{N}_{2} \mathrm{O}$ concentrations in the open ocean, reaching up to $2900 \mathrm{nmol} / \mathrm{L}$ and $436 \mathrm{nmol} / \mathrm{L}$, respectively [Naqvi et al., 2006, 2010; Brüchert et al., 2009]. However, many coastal and low oxygen areas have not been well-studied. High uncertainty in the estimates of global 
oceanic emissions of $\mathrm{CH}_{4}$ and $\mathrm{N}_{2} \mathrm{O}$ exists due to the poor sampling resolution in key regions and large ambiguity in sea-air fluxes in many under-sampled areas.

\section{$1.2 \mathrm{CH}_{4}$ AND $\mathrm{N}_{2} \mathrm{O}$ IN THE ARCTIC OCEAN}

The Arctic Ocean is thought to be a potentially significant source of $\mathrm{CH}_{4}$ and $\mathrm{N}_{2} \mathrm{O}$ to the atmosphere, and one that is particularly poorly sampled. The Arctic Ocean's large, shallow continental shelves are sites of significant $\mathrm{CH}_{4}$ and $\mathrm{N}_{2} \mathrm{O}$ production and emission. $\mathrm{CH}_{4}$ and $\mathrm{N}_{2} \mathrm{O}$ super-saturation of up to $125 \%$ and $\sim 500 \%$, respectively, has been documented in the surface waters of the Chukchi Sea [Savvichev et al., 2007; Hirota et al.,

2009]. The high carbon export in this region is thought to generate $\mathrm{CH}_{4}$ and $\mathrm{N}_{2} \mathrm{O}$ through the decomposition of organic matter in the sediments [Savvichev et al., 2007; Chang and Devol, 2009; Hirota et al., 2009]. In addition, very high surface concentrations of $\mathrm{CH}_{4}$ in the Eurasian Seas, (mean $18 \mathrm{nmol} / \mathrm{L}$ ), has been attributed to the thawing of subsea permafrost on these marginal shelves [Shakhova et al., 2010a; Kosmach et al., 2015], while a lesser degree of $\mathrm{CH}_{4}$ super-saturation has been previously found in the permafrost-free Chukchi Sea [Savvichev et al., 2007; Kosmach et al., 2015]. Sea ice also plays a role in regulating these gases by restricting sea-air flux and diluting surface water with low- $\mathrm{CH}_{4}$ and $\mathrm{N}_{2} \mathrm{O}$ melt water [Randall et al., 2012; He et al., 2013]. Recently, sea ice processes have been identified as potential $\mathrm{CH}_{4}$ and $\mathrm{N}_{2} \mathrm{O}$ sources associated with microbial activity in anoxic brine channels [Damm et al., 2015a]. In the surface water of the Northwest Passage, the highest $\mathrm{CH}_{4}$ and $\mathrm{N}_{2} \mathrm{O}$ concentrations were under sea ice, while much lower concentrations were observed in open ocean [Kitidis et al., 2010].

Examination of Arctic $\mathrm{CH}_{4}$ and $\mathrm{N}_{2} \mathrm{O}$ sources is particularly important in light of the rapid climate-dependent changes occurring in this region. Changes caused by warming alter the biology, chemistry, and circulation of the ocean. Arctic sea ice cover has been drastically thinned and reduced over the past 30 years [Maslanik et al., 2011]. This reduction in sea ice could augment the sea-air flux of $\mathrm{CH}_{4}$ and $\mathrm{N}_{2} \mathrm{O}$ by lessening exposure to consumption processes [Kitidis et al., 2010], but it may also influence the carbon and nitrogen cycles. The shorter ice cover period and longer growing season has resulted in a $30 \%$ increase in primary production in the Arctic Ocean and a northward shift of many species [Arrigo and van Dijken, 2011, 2015; Grebmeier, 2012]. The increased flux of organic 
matter to the sediments may result in greater $\mathrm{CH}_{4}$ and $\mathrm{N}_{2} \mathrm{O}$ production due to decomposition processes. The thawing of subsea permafrost may introduce additional organic matter to the system, further increasing the production of these gases, as has been shown in the Eastern Siberian Arctic Seas [Shakhova et al., 2015] and wetland sites in the high Arctic [Elberling et al., 2010]. However, new evidence suggests that efficient anaerobic oxidation of $\mathrm{CH}_{4}$ within the sediments may have the capacity to drastically limit the $\mathrm{CH}_{4}$ flux to the ocean from this source [Overduin et al., 2015]. Warming bottom waters have also caused the destabilization of gas hydrates, which require low temperatures and high pressures to remain stable on the continental slope, and have possibly accelerated the decomposition of the subsea permafrost "cap" which contains hydrates within continental shelf sediment [Ruppel, 2015; Shakhova et al., 2015]. Gas hydrates, although very localized, have been shown to be regionally important sources of $\mathrm{CH}_{4}$ [e.g., Heeschen et al., 2005;

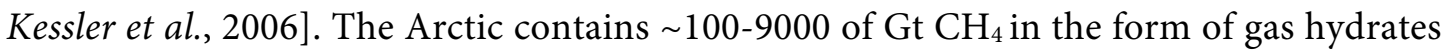
[James et al., 2016]. The potential destabilization and sudden release of this huge carbon store has attracted much attention due to its association with previous climate change [Dickens et al., 1995, 1997; Lamarque et al., 2006; Archer, 2007; Archer et al., 2009]. Without significant baseline data on the concentrations of $\mathrm{CH}_{4}$ and $\mathrm{N}_{2} \mathrm{O}$ across varying hydrographic regimes, it is difficult to predict how their concentrations will change into the future.

At present, our understanding of the controls on $\mathrm{CH}_{4}$ and $\mathrm{N}_{2} \mathrm{O}$ cycling in the Arctic Ocean is incomplete. Previous biogeochemical studies in the Arctic Ocean have been spatially segregated [Carmack and Wassmann, 2006], with particular programs focusing on localized regions of interest (e.g. the Bering and Chukchi Seas, Canada Basin, Beaufort Sea, or Davis Strait; Kvenvolden et al., 1993; Hirota et al., 2009; Punshon et al., 2014; Zhan et al., 2015). These studies have shown that $\mathrm{CH}_{4}$ and $\mathrm{N}_{2} \mathrm{O}$ are frequently supersaturated in the Arctic surface ocean with respect to atmospheric equilibrium values. Studies of Arctic $\mathrm{CH}_{4}$ distributions have focused on the continental shelves, where surface waters are highly supersaturated [e.g., Kvenvolden et al., 1993; Savvichev et al., 2007; Shakhova et al., 2010a], with the greatest attention paid to the high sea-air fluxes in the Siberian Arctic Seas [Shakhova and Semiletov, 2007; Shakhova et al., 2010b, 2013; Kosmach et al., 2015]. By comparison, few studies have sampled the deep basin waters [Damm et al., 2010; Punshon 
et al., 2014] or in the Canadian Arctic [Kvenvolden et al., 1993; Kitidis et al., 2010; Punshon et al., 2014]. Previous work on $\mathrm{N}_{2} \mathrm{O}$ has demonstrated high concentrations in the Chukchi Sea [Hirota et al., 2009; Zhang et al., 2015], under-saturation in the deep Canada Basin [Zhan et al., 2015], and low concentrations in sea-ice melt water [Kitidis et al., 2010; Randall et al., 2012; Zhang et al., 2015]. Kitidis et al. [2010] reported measurements of surface water $\mathrm{CH}_{4}$ and $\mathrm{N}_{2} \mathrm{O}$ concentrations across a broad range of Arctic waters. Their results revealed notable spatial patterns, including 'hot-spots' of high $\mathrm{CH}_{4}$ and $\mathrm{N}_{2} \mathrm{O}$ under sea ice and in marginal ice zones. These observations are consistent with the recently suggested role of sea-processes as potential $\mathrm{CH}_{4}$ and $\mathrm{N}_{2} \mathrm{O}$ sources [Damm et al., 2015a], though more depth-resolved observations are needed to further examine this. The work of Kitidis et al. [2010] was largely focused on surface waters (only one depth profile was presented), and thus provided little insight into distribution of $\mathrm{CH}_{4}$ and $\mathrm{N}_{2} \mathrm{O}$ in sub-surface waters.

The goal of this study was to examine broad-scale, three-dimensional distribution of $\mathrm{CH}_{4}$ and $\mathrm{N}_{2} \mathrm{O}$ concentrations in the North American Arctic Ocean. During the summer of 2015, depth profiles at nearly 50 locations from the Bering Sea to Baffin Bay were taken in order to quantify the distributions of $\mathrm{CH}_{4}$ and $\mathrm{N}_{2} \mathrm{O}$ concentrations and sea-air fluxes, and examine potential source and sink terms (Figure 1). To my knowledge, the data set presented here represents the most comprehensive analysis of Arctic $\mathrm{CH}_{4}$ and $\mathrm{N}_{2} \mathrm{O}$ distributions across a single sampling season. The temporal coherence of the measurements is critical given the rapid changes currently underway in the Arctic. Our results show that $\mathrm{N}_{2} \mathrm{O}$ is produced in the Bering and Chukchi Seas, and transported with Pacific water masses through to Baffin Bay, with dominant input terms associated with nitrification and denitrification in the Western Arctic. In contrast, $\mathrm{CH}_{4}$ sources to the water column were far more ephemeral, with rapid microbial oxidation of $\mathrm{CH}_{4}$ acting to decrease concentrations and limit eastward transport of $\mathrm{CH}_{4}$. The carbon isotopic composition of $\mathrm{CH}_{4}$ supported this conclusion, as low $\mathrm{CH}_{4}$ concentrations were enriched in ${ }^{13} \mathrm{C}$ due to oxidative processes. This synoptic coverage provides a snapshot of spatial $\mathrm{CH}_{4}$ and $\mathrm{N}_{2} \mathrm{O}$ variability, and an important baseline dataset for this rapidly changing ocean region. 


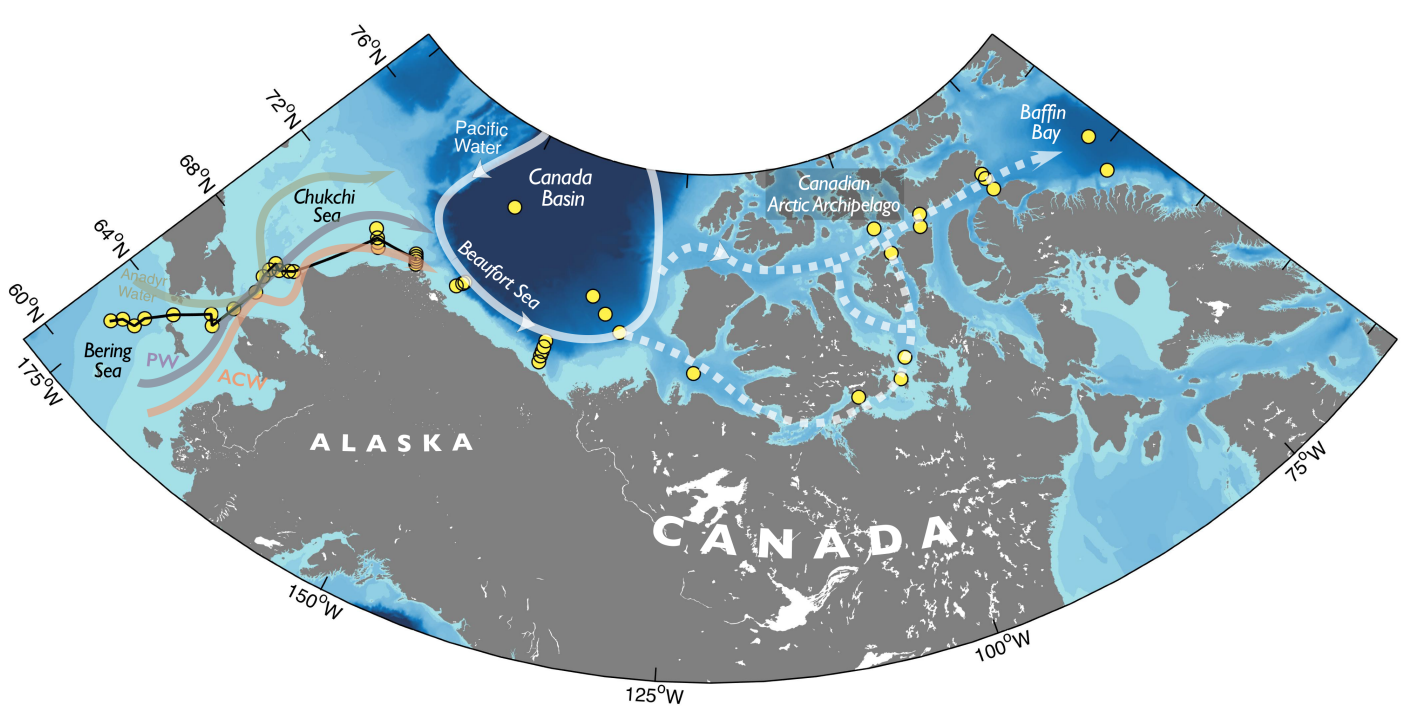

Figure 1: Map of study area, showing the locations of depth profiles (yellow circles) and dominant Pacific Water boundary currents. The black line denotes the transect along which the contour plots (Figure 5 and Figure 10) were derived. Based on [Macdonald et al., 2004]. 


\section{Methods and Regional Setting}

\subsection{FIELD SAMPLING}

Water samples were collected on three cruises over the period between July to October 2015, covering a transect from the Bering Sea to Baffin Bay (Table 1, Figure 1). At each of the 47 stations, a Sea-Bird CTD system (SBE 911+), equipped with ancillary sensors was used to measure salinity, temperature, and other hydrographic parameters. Discrete water samples for the various stations were collected at multiple depths using $10 \mathrm{~L}$ Niskin bottles mounted on a rosette. Salinity values measured by CTD were calibrated against discrete bottle samples analyzed on an Autosal salinometer calibrated to IAPSO standard seawater [Millero et al., 2008].

Table 1: Cruise details

\begin{tabular}{lllll}
\hline Ship & Cruise Number & Dates & Regions & Program(s) \\
\hline $\begin{array}{llll}\text { CCGS Sir Wilfrid } \\
\text { Laurier }\end{array}$ & SWL 2015-07 & $04 / 07 / 16-$ & Bering Sea, Chukchi Sea & C3O, DBO \\
CCGS Amundsen & 1502 & $26 / 07 / 16$ & & ArcticNet, \\
& & $10 / 07 / 16-$ & Baffin Bay, Canadian & GEOTRACES \\
CCGS Louis St. & LSSL 2015-06 & $20 / 07 / 16$ & Archipelago & JOIS \\
Laurent & & $17 / 10 / 16$ & Canada Basin, Beaufort Sea & \\
\hline
\end{tabular}

\subsection{Dissolved GAS CONCENTRATIONS AND $\delta^{13} \mathrm{C}_{\mathrm{CH}_{4}}$ VALUES}

Water for $\mathrm{CH}_{4}$ and $\mathrm{N}_{2} \mathrm{O}$ analysis was sub-sampled from Niskin bottles into $60 \mathrm{~mL}$ glass vials using thick-walled silicon tubing. Sample vials were overfilled three times and poisoned with $100 \mu \mathrm{L}$ of saturated $\mathrm{HgCl}_{2}$, taking care to avoid entrainment of bubbles while filling bottles. Bottles were crimp sealed with no headspace using butyl-rubber stoppers 
and aluminum caps. Duplicate samples were taken at each depth, and stored at $4^{\circ} \mathrm{C}$ in the dark until analysis within $\sim 1$ month of sampling. $\mathrm{CH}_{4}$ and $\mathrm{N}_{2} \mathrm{O}$ concentrations were measured simultaneously using an automated purge and trap gas extraction system coupled with gas chromatograph-mass spectrometer (PT-GCMS) at the University of British Columbia according to the method of Capelle et al. [2015]. The pooled standard deviations of the duplicates were 0.88 and $0.58 \mathrm{nmol} / \mathrm{L}$ for $\mathrm{CH}_{4}$ and $\mathrm{N}_{2} \mathrm{O}$ measurements, respectively. As discussed by Capelle et al. [2015], the accuracy and precision of our automated system compares very well against methods by other leading laboratories around the world. Percent saturation relative to atmospheric equilibrium was calculated from the mean concentration of the duplicate samples and gas solubility was calculated following Wiesenburg and Guinasso Jr. [1979] and Weiss and Price [1980] for $\mathrm{CH}_{4}$ and $\mathrm{N}_{2} \mathrm{O}$, respectively, using the CTD measured in situ temperature and salinity. Atmospheric concentrations of $\mathrm{CH}_{4}$ and $\mathrm{N}_{2} \mathrm{O}$ were taken as $1910 \mathrm{ppb}$ and $328 \mathrm{ppb}$, respectively, based on the average mixing ratios in Barrow, Alaska in August 2015 (Data provided by NOAA ESRL Global Monitoring Division, Boulder, Colorado, USA; http://esrl.noaa.gov/gmd/).

Samples for $\delta^{13} \mathrm{C}_{\mathrm{CH} 4}$ analysis were collected in either $160 \mathrm{~mL}$ or $250 \mathrm{~mL}$ glass vials in the same manner as above, and poisoned with either $300 \mu \mathrm{L}$ or $500 \mu \mathrm{L} \mathrm{HgCl}_{2}$, respectively. The values were determined using a Delta XP plus Finnigan mass spectrometer at the Alfred Wegner Institute in Bremerhaven, Germany. The samples were pre-concentrated through purging and subsequent trapping with PreCon equipment (Finnigan), and the isotopic ratios were given in delta notation relative to the Vienna Pee Dee Belemnite (VPDB) standard.

\subsection{NUTRIENT ANALYSIS}

For cruise LSL 2015-06, unfiltered nutrient samples from were analyzed for nitrate + nitrite, phosphate, and silicate on a three channel Seal Analytical Nutrient Auto-Analyser 3 (AA3) within 12 hours of collection. For cruise SWL 2015-07, nutrient samples were analysed by the same method, but were frozen prior to being analyzed at the Institute of Ocean Sciences 5 months after the cruise. Unfrozen ammonium $\left(\mathrm{NH}_{4}{ }^{+}\right)$samples were analyzed by the Nutrient Analytical Services Laboratory at the University of Maryland, following the method described in Parsons et al. [1984]. 


\subsection{BIOGEOCHEMICAL CALCULATIONS}

$\mathrm{N}^{*}$ is a measure of the relative excess or deficit of fixed nitrogen relative to phosphate, calculated using the equation $\mathrm{N}^{\star}(\mu \mathrm{mol} / \mathrm{L})=\left(\left[\mathrm{NO}_{3}{ }^{-}\right]+\left[\mathrm{NO}_{2}{ }^{-}\right]+\left[\mathrm{NH}_{4}{ }^{+}\right]-16^{*}\left[\mathrm{PO}_{4}{ }^{3-}\right]+2.9\right.$ of [Gruber and Sarmiento, 1997]. Assuming Redfield stoichiometry (C:N:P = 106:16:1), a negative $\mathrm{N}^{\star}$ value indicates a deficit of dissolved inorganic nitrogen, while a positive value indicates N fixation [Redfield, 1942; Gruber and Sarmiento, 1997]. Apparent oxygen utilization (AOU) represents the amount of oxygen that has been consumed by remineralization since the water mass was last ventilated. AOU is calculated as difference between the dissolved oxygen concentration measured in a sample and the calculated concentration at equilibrium with the atmosphere [Redfield, 1942]. For the purposes of these calculations, we (and others) assume that temperature and salinity characteristics of waters masses have not been altered since they were last in contact with the atmosphere.

\subsection{SEA-AIR FLUX CALCULATIONS}

Sea-air fluxes of $\mathrm{CH}_{4}$ and $\mathrm{N}_{2} \mathrm{O}\left(\mu \mathrm{mol} \mathrm{m}{ }^{-2} \mathrm{~d}^{-1}\right)$ at each station were calculated using a mixed layer depth computed based on a density difference criterion of $0.125 \mathrm{~kg} \mathrm{~m}^{-3}$ relative to $3 \mathrm{~m}$ depth. If no measurement was taken within this calculated mixed layer, measurements within $3 \mathrm{~m}$ of the mixed layer depth were used instead for flux calculations. The disequilibrium of $\mathrm{CH}_{4}$ and $\mathrm{N}_{2} \mathrm{O}$ in the mixed layer was calculated by subtracting the atmospheric saturation value (by the same method described in section 2.2) from the observed concentration. Wind data were acquired from the NCEP Reanalysis data provided by the NOAA/OAR/ESRL PSD, Boulder, Colorado, USA, from their website at http://www.esrl.noaa.gov/psd/. The equation for the ocean-atmosphere flux was taken as the product of a gas exchange coefficient, $\mathrm{k}_{\mathrm{w}}$, and mixed layer disequilibrium, $\Delta \mathrm{C}$ :

$$
\text { Flux }=\mathrm{k}_{\mathrm{w}} \times \Delta \mathrm{C}
$$

The gas exchange coefficient $\left(\mathrm{k}_{\mathrm{w}}\right)$ was calculated as a function of the Schmidt number (Sc) and wind speed according to the parameterization by Nightingale et al. [2000]. This equation was developed for ice-free conditions, which is appropriate for our calculations

since we did not have any mixed layer gas samples for ice-covered stations. A weighting function [Reuer et al., 2007] was used to incorporate the effects of variability in wind speeds 
in the 60 days prior to sample collection. The net result is a time-weighted piston velocity, where the weighting is based on the fraction of the mixed layer ventilated on any given day.

\subsection{REGIONAL SETTING}

In order to provide a context for our $\mathrm{CH}_{4}$ and $\mathrm{N}_{2} \mathrm{O}$ concentration data, we briefly review the dominant oceanographic properties of our broad survey region. We sampled across a number of distinct water masses, which are influenced by a range of physical and biological processes that impact salinity, temperature, and nutrient concentrations. These tracers allow us to better constrain the biogeochemical processes that influence trace gas cycling. We also briefly review the available information on $\mathrm{CH}_{4}$ emissions from seafloor sediments across our survey region.

\subsubsection{Bering and Chukchi Seas}

The Bering and Chukchi Seas are dominated by northward flowing Pacific water that comprises several distinct water masses. As these water masses transit over the shallow Bering and Chukchi Shelves into the Arctic Basin, they are modified by biological and physical processes [e.g., Yamamoto-Kawai et al., 2006]. In the northern region of the Bering shelf, three main water masses are present in the summer. The Anadyr Water occupies the western portion of the Bering Sea, and is composed of upwelled, saline, nutrient-rich deep water in the Gulf of Anadyr. The eastern Bering Sea is dominated by relatively fresh $(\mathrm{S}<31.8)$, nutrient-poor $\left(<1.5 \mu \mathrm{mol} / \mathrm{L} \mathrm{NO}_{3}{ }^{-}\right)$Alaskan Coastal Water $(\mathrm{ACW})$. A central water mass with intermediate salinity is known as Bering Sea Water (BSW). Mixing of the BSW and Anadyr Water is enhanced in the Northern Bering Sea and Bering Strait, but some unaltered Anadyr Water and ACW persists into the Chukchi Sea [Weingartner et al., 2005; Grebmeier et al., 2006]. The BSW contains high dissolved nutrient concentrations due to the influence of the Anadyr Water, but seasonal differences in sea ice growth results in two distinct water masses, known as Pacific Winter Water (PWW) and the Pacific Summer Water (PSW). In the winter, convective overturning caused by brine rejection stirs up the sediments and adds regenerated sedimentary nutrients to the PWW [Pickart et al., 2016], while imparting a low temperature and high 
salinity signature [e.g., Woodgate et al., 2005a; 2005b]. During summer, the fresher, northward flowing PSW gradually displaces the PWW on the Chukchi shelf, although remnant PWW is still present on the northern Chukchi Shelf [e.g., Lowry et al., 2015; Pickart et al., 2016]. At the northern-most point in our study area, in Barrow Canyon, all of these water masses converge and stratify [Gong and Pickart, 2015]. The dense PWW sinks to the deepest parts of the canyon (below $35 \mathrm{~m}$ depth) and is overlain by PSW and ACW (5 - $35 \mathrm{~m})$ as well as a surface melt-water layer (0 - $5 \mathrm{~m})$ [Gong and Pickart, 2015].

The contrasting nutrient concentrations in the different water masses affect primary production, which has important implications for $\mathrm{CH}_{4}$ and $\mathrm{N}_{2} \mathrm{O}$ cycling. The high nutrient BSW sustains an annual productivity of up to $\sim 500-700 \mathrm{~g} \mathrm{C} \mathrm{m}^{-2} \mathrm{y}^{-1}$ in the northern Bering and southern Chukchi Seas, with values declining to $\sim 50-100 \mathrm{~g} \mathrm{C} \mathrm{m}^{-2} \mathrm{y}^{-1}$ in the northern Chukchi Sea [Hameedi, 1978; Springer and McRoy, 1993]. By contrast, the nutrient-poor southeastern Chukchi Sea supports primary production of less than $100 \mathrm{C} \mathrm{m}^{-2} \mathrm{y}^{-1}$ [Springer and McRoy, 1993]. This east-west productivity gradient is also reflected in organic carbon fluxes and benthic oxygen consumption rates, which are both significantly higher in regions of elevated primary productivity [Naidu et al., 2004]. The high oxygen consumption rates in the productive regions result in sediment anoxia, creating conditions conducive to anaerobic microbial processes associated with $\mathrm{CH}_{4}$ and $\mathrm{N}_{2} \mathrm{O}$ production. Indeed, denitrification has been well documented on the Bering and Chukchi shelves [Devol et al., 1997; Tanaka et al., 2004; Yamamoto-Kawai et al., 2006], and methanogenesis has also been reported [Savvichev et al., 2007]. These processes could add $\mathrm{CH}_{4}$ and $\mathrm{N}_{2} \mathrm{O}$ to the water column in the Bering and Chukchi, which could potentially be transported to other regions of the Arctic by eastward flowing waters.

Rivers are another potential source of $\mathrm{CH}_{4}$ and $\mathrm{N}_{2} \mathrm{O}$ to surface waters of the Western Arctic, delivering $\mathrm{CH}_{4}$ released from terrestrial permafrost, and $\mathrm{CH}_{4}$ and $\mathrm{N}_{2} \mathrm{O}$ produced in riverine sediments to coastal regions. The Yukon River, whose drainage basin contains near-surface permafrost [Pastick et al., 2014], is the second largest river in the North American Arctic [Cooper et al., 2008]. Yukon river water feeds directly into the ACW, and high measured concentrations of $\mathrm{CH}_{4}$ (up to $330 \mathrm{nmol} / \mathrm{L}$ ) in this river and its tributaries have been attributed to the anoxic decomposition of the organic matter in its watershed [Striegl et al., 2012]. We are unaware of any $\mathrm{N}_{2} \mathrm{O}$ data for the Yukon River. 


\subsubsection{Canada Basin and Beaufort Sea}

The Canada Basin comprises deep waters ( $4000 \mathrm{~m})$ bordered by shallow seas and continental shelf. Surface waters of the Canada Basin are characterized by a $\sim 40 \mathrm{~m}$ thick Polar Mixed Layer (PML) that is relatively fresh (26.2-31.2\%o) and nutrient-depleted [Macdonald et al., 2004]. As Pacific waters enter the Canada Basin from the Chukchi Sea, they subduct below the PML into the Upper Halocline Layer (UHL) [Codispoti et al., 2009]. Within the UHL, Pacific Summer Water (PSW) $\left(S=31-32, T>-1^{\circ} \mathrm{C}, \mathrm{D}=25-26 \sigma_{\mathrm{t}}\right)$ is found between $\sim 40-100 \mathrm{~m}$, while Pacific Winter Water (PWW) $\left(\mathrm{S}=32-33.1, \mathrm{~T}<-1^{\circ} \mathrm{C}, \mathrm{D}=26-26.5\right.$ $\sigma_{\mathrm{t}}$ ) sits between $\sim 100-200 \mathrm{~m}$. Previous authors have used a salinity of 33.1 and temperature of $-1.6^{\circ} \mathrm{C}$ as the signature characteristics of the PWW core [e.g., Aagaard et al., 1981; Jones and Anderson, 1986; Carmack, 2000]. The ACW is only a very minor component of the UHL, and is generally considered part of the PSW once it enters the basin [Shimada et al., 2001]. Below the UHL, the Lower Halocline Layer occupies a depth range of $\sim 200-400 \mathrm{~m}$ and is largely of Atlantic origin, while Canada Basin Intermediate Water (CBIW) occupies a depth range of $\sim 400-2000 \mathrm{~m}$. Canada Basin Deep Water (CBDW), which is found below $\sim 2000 \mathrm{~m}$, has been isolated from the atmosphere for $\approx 450$ years [Schlosser et al., 1997; McLaughlin et al., 2002; Timmermans et al., 2003].

Strong salinity stratification in the surface waters of the Canada Basin results in low surface water nutrient concentrations and, thus, restricted primary productivity [Sakshaug, 2004]. This, in turn, results in low carbon export to sub-surface waters, which have been isolated from the atmosphere for decades or longer [Macdonald et al., 2004]. As a result, the chemistry of deep basin waters is relatively homogenous [Timmermans et al., 2003]. The Beaufort Sea, in the southern Canada Basin, is primarily influenced by the Upper Halocline water masses of the Canada Basin, including both PSW and PWW [Carmack et al., 2006]. Additionally, the ACW wraps around Barrow Point and is transported into the Beaufort Sea. This inflowing ACW is retained close to the coast, and was not likely sampled during our surveys. The carbon export in the ACW inflow is considerably lower than that of the Bering and Chukchi Seas (due to lower nutrient concentrations), resulting in lower benthic productivity and oxygen consumption [Naidu et al., 2004]. 


\subsubsection{Canadian Arctic Archipelago}

The Canadian Arctic Archipelago (CAA) is a vast stretch of islands and channels that lies to the north-east of the Beaufort Sea (Figure 1). This region receives Pacific-derived water from the west, with PML and UHL waters flowing eastward over the sill demarcating the entrance to the Amundsen Gulf. Westward flow is limited by a shallow sill near Resolute, such that almost all of the water in the CAA (even as far east as Lancaster Sound) is derived from Pacific-origin water masses with only a limited influence of Atlanticderived waters [Jones, 2003; Michel et al., 2006]. The complex network of shallow, narrow straits in the CAA is subject to significant regional and small-scale variability. River input modifies the inflowing water, and imparts a low salinity signature on the southern CAA [McLaughlin et al., 2004]. Local mixing and tidal processes through the narrow straits and channels also reduce stratification and increase nutrient concentrations [McLaughlin et al., 2004, 2011]. High sea ice cover also influences biogeochemical cycling in the CAA. Sea ice acts as a semi-permeable barrier to sea-air exchange of dissolved gasses [e.g., Loose et al., 2011], and has been suggested as an explanation for the accumulation of high $\mathrm{CH}_{4}$ and $\mathrm{N}_{2} \mathrm{O}$ concentrations in the surface waters of the CAA [Kitidis et al., 2010; Damm et al., 2015a].

Primary productivity estimates in the CAA vary from 10 to $55 \mathrm{~g} \mathrm{C} \mathrm{m}^{-2} \mathrm{y}^{-1}$ [Welch et al., 1992; Sakshaug, 2004]. Sea ice algae are an important part of this production, contributing 5 to $10 \mathrm{~g} \mathrm{C} \mathrm{m}^{-2} \mathrm{y}^{-1}$ [Smith et al., 1988; Michel et al., 2006]. The linkages between primary productivity and benthic remineralization have not been well-studied within the CAA, but recent data have shown relatively high benthic remineralization rates in Lancaster Sound, and much lower rates in the Amundsen Gulf and Baffin Bay [Darnis et al., 2012]. Regions with high remineralization rates may be sources of $\mathrm{CH}_{4}$ and $\mathrm{N}_{2} \mathrm{O}$ to the CAA.

\subsubsection{Seafloor methane sources}

The shallow shelves of the Arctic Ocean were once vast coastal plains which developed layers of thick permafrost during the Late Pleistocene (Brigham and Miller, 1983). Gas from petroleum deposits or biological production deep in the crust migrated upwards and was frozen in place as gas hydrates [Ruppel, 2015]. A post-glacial sea level rise of $120 \mathrm{~m}$ since $\sim 12 \mathrm{ka}$ inundated these plains, thawing the permafrost deposits and likely causing the 
dissociation of permafrost-associated gas hydrates [Ruppel, 2015]. This release of gas in unstable hydrates, either entrained in or capped by a permafrost layer, are thought to be the sources of the large methane emissions on the wide Eastern Siberian Arctic Shelf and other Eurasian shelves [Shakhova et al., 2010b, 2015]. In contrast, the North American Arctic only holds permafrost deposits (extending to $\sim 100 \mathrm{~m}$ depth) and shallow gas hydrates on the narrow Beaufort Shelf [Paull et al., 2007, 2011; Ruppel, 2015]. Widespread gas plumes have been documented on the continental margin of the Beaufort Sea, and these have been attributed to decomposing permafrost and gas hydrates [Paull et al., 2011]. Deepwater gas hydrates ( 300-1200m) are also present on the Beaufort Slope [Weaver, J.S., Stewart, 1982; Dallimore, 1999; Ruppel, 2015]. These hydrates on the continental slope are generally considered the most sensitive to disruption due to climate change [Kvenvolden, 1993; Ruppel, 2011]. Warming over the past 60 years has been implicated in the potential destabilization of gas hydrate deposits between 300 and $550 \mathrm{~m}$ depth [Phrampus et al., 2014]. Additionally, a survey of the slope sediments has shown elevated sediment-ocean fluxes of $\mathrm{CH}_{4}$ from 280-1500 $\mathrm{m}$ depth on the western Beaufort slope, potentially attributable to gas hydrate dissociation [Coffin et al., 2013].

Hydrocarbon deposits may also play a role as a $\mathrm{CH}_{4}$ source. Much of the Chukchi Sea and Canada Basin, including the Beaufort Sea, is underlain by hydrocarbon-bearing source rocks [Burlin and Shipel'kevich, 2006; Grantz and Hart, 2012]. These can contribute $\mathrm{CH}_{4}$ to the water column though upward migrations along faults and fractures in the rock [Reeburgh, 2007]. Thermogenic gas seepages are widespread in areas where oil and gas deposits occur, and are often used as targets of commercial exploration [Hovland et al., 1993]. However, there is only limited published information on the exact location of such seepage sites [Hovland et al., 1993]. As the Chukchi and Beaufort Seas have been extensively explored for offshore oil and gas, it is likely that thermogenic seepages exist in these areas and contribute to the $\mathrm{CH}_{4}$ cycling. 


\section{Results and Discussion}

For the purpose of describing gas distributions, we divide our study area into three sub-regions: a) Bering Sea and Chukchi Sea, b) Canada Basin and Beaufort Sea, and c) Canadian Arctic Archipelago and Baffin Bay. This grouping was based on the similarity of hydrography and $\mathrm{CH}_{4}$ and $\mathrm{N}_{2} \mathrm{O}$ distributions within these regions. We first provide an overview of $\mathrm{CH}_{4}$ and $\mathrm{N}_{2} \mathrm{O}$ concentrations across our full transect, and then focus on the processes occurring in each of these sub-regions. Since the cycling of $\mathrm{CH}_{4}$ and $\mathrm{N}_{2} \mathrm{O}$ is influenced by distinct biogeochemical processes, we discuss each of these gases separately.

\subsection{NITROUS OXIDE}

Nitrous oxide concentrations across the entire transect ranged from 10.9 to 24.6 $\mathrm{nmol} / \mathrm{L}$, with corresponding saturation levels of $77 \%$ to $145 \%$. As shown in Fig. 2, concentrations of $\mathrm{N}_{2} \mathrm{O}$ exhibited a ubiquitous maximum in the Pacific Winter Water (PWW), with persistent low values in the surface fresh-water layer and ACW (Figure 2). This feature can be seen in Fig. 3, where the average profiles of $\mathrm{N}_{2} \mathrm{O}$ from the Bering, Chukchi and Beaufort Seas, and the CAA region are plotted on density surfaces. As discussed below, this high $\mathrm{N}_{2} \mathrm{O}$ signal in the PWW originates in the Bering and Chukchi Seas and is transported across the Arctic Ocean on the $26.5 \sigma_{\mathrm{t}}$ density surface until it is attenuated in the Canadian Arctic Archipelago. In deeper waters, $\mathrm{N}_{2} \mathrm{O}$ concentrations tend to decrease with increasing density, while $\mathrm{N}_{2} \mathrm{O}$ concentrations in the lower-density surface waters are more variable because they are influenced by sea-ice cover, water mass mixing, and sea-air exchange. 


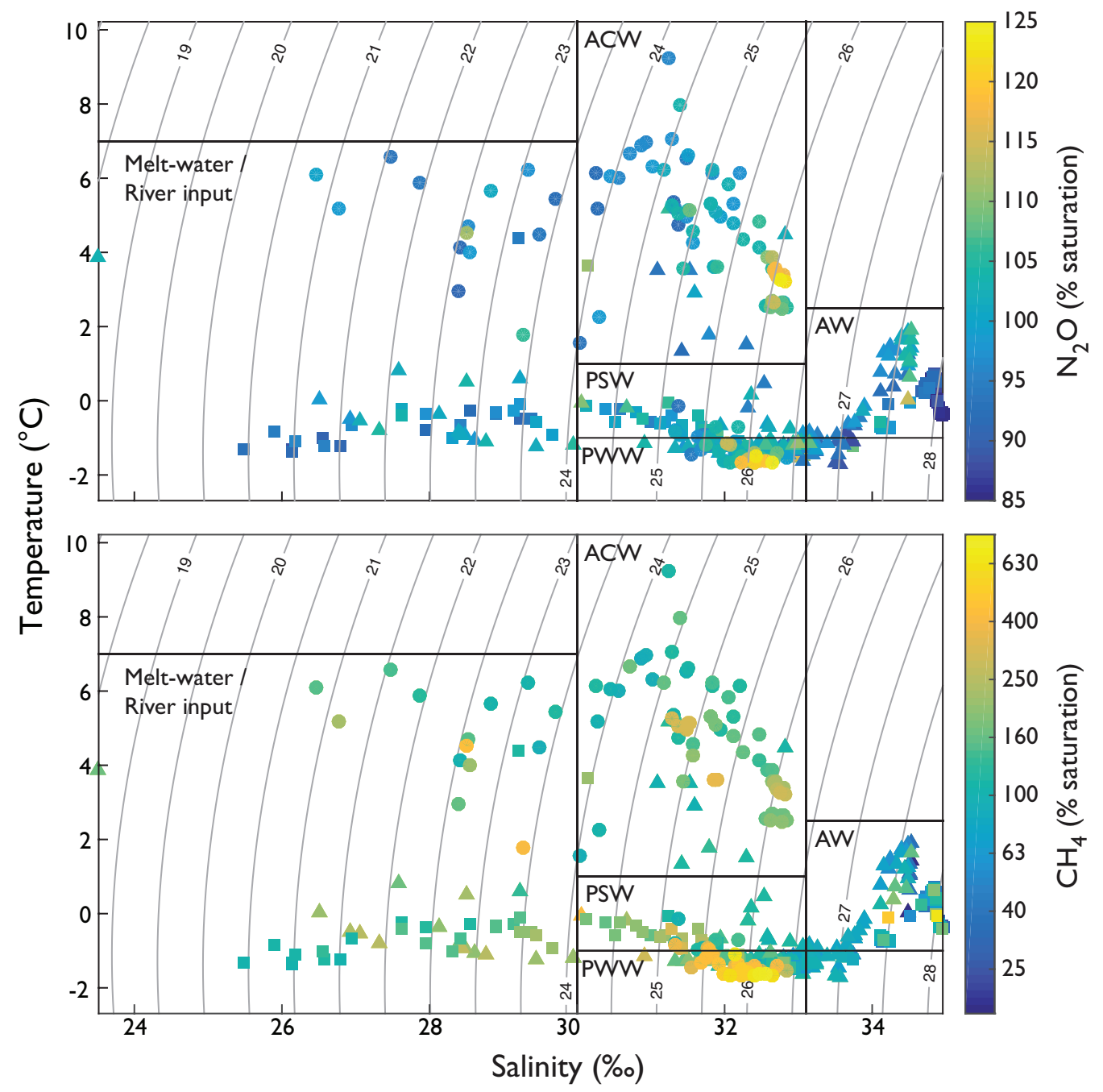

Figure 2: Salinity vs. temperature plot showing the different water masses observed in the North American Arctic. The top panel shows percent saturation of $\mathrm{N}_{2} \mathrm{O}$, while the bottom panel shows percent saturation of $\mathrm{CH}_{4}$. Circles, squares, and triangles denote measurements from the Bering and Chukchi Seas, Canada Basin, and Canadian Arctic Archipelago, respectively. 


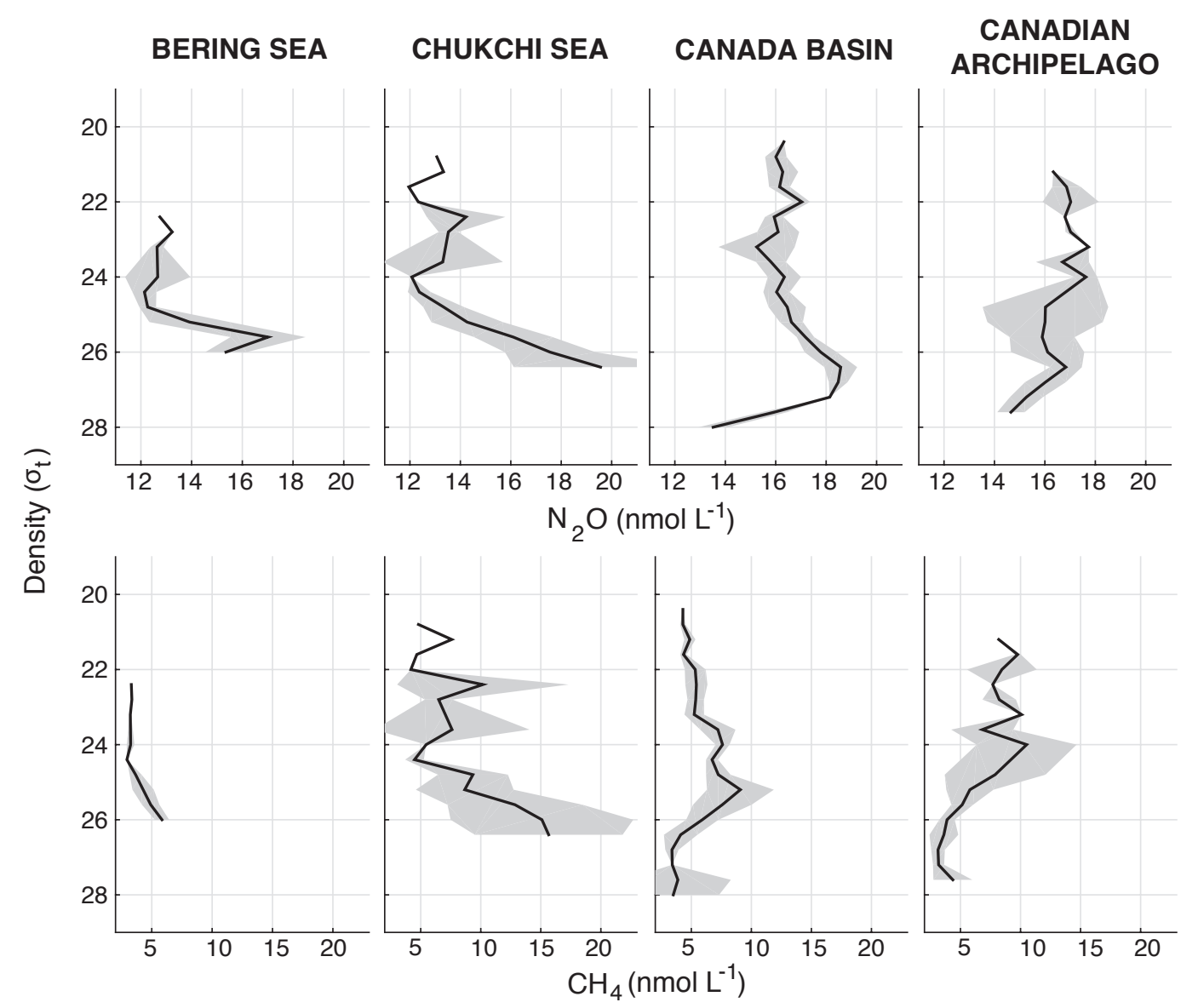

Figure 3: Density vs. concentration plots averaged by sub-region. The grey shaded area is the standard deviation of the mean.

\subsection{1 $\mathrm{N}_{2} \mathrm{O}$ in the Bering and Chukchi Seas}

Across all sampling depths, $\mathrm{N}_{2} \mathrm{O}$ concentrations ranged from values just under atmospheric equilibrium in the Northern Bering Sea $(11.8 \mathrm{nmol} / \mathrm{L})$ to a maximum of 24.6 $\mathrm{nmol} / \mathrm{L}$ (145\% saturation) at the northernmost station in the Chukchi Sea (Figure 4). Surface water $\mathrm{N}_{2} \mathrm{O}$ concentrations were low, and typically less than the atmospheric equilibrium concentration of $\sim 13 \mathrm{nmol} / \mathrm{L}$. These concentrations are consistent with observations reported previously for this region ( 11-25 nmol/L) [Hirota et al., 2009; Zhang et al., 2015]. The nearly ubiquitous under-saturation of $\mathrm{N}_{2} \mathrm{O}$ in surface waters may reflect dilution by sea ice meltwater which contains little $\mathrm{N}_{2} \mathrm{O}$ [Randall et al., 2012]. In contrast to previous observations in our study area [Hirota et al., 2009; Zhang et al., 2015] we did not detect high (>120\%) surface super-saturations of $\mathrm{N}_{2} \mathrm{O}$ in the Bering and 
Chukchi Seas. The lower concentrations we observed may reflect a difference in the geographic region and/or seasonal timing of our sampling compared to previous studies. Hirota et al. [2009] sampled stations further to west, with significant influence of highnutrient Anadyr Water, which likely fuels high productivity and oxygen depletion in the sediments leading to increased $\mathrm{N}_{2} \mathrm{O}$ concentrations.

Below the surface layer, $\mathrm{N}_{2} \mathrm{O}$ distributions appeared to be influenced by local water masses and biological processes in the sediments. In particular, differences in nutrient availability and biological productivity across distinct water masses appeared to influence $\mathrm{N}_{2} \mathrm{O}$ accumulation as water transited through the Bering and into the Chukchi Sea. The northern Bering Sea contained low and near atmospheric equilibrium $\mathrm{N}_{2} \mathrm{O}$ concentrations throughout the water column, averaging $14.4 \mathrm{nmol} / \mathrm{L}$ (Figure 4). In the southern Chukchi Sea, two separate patterns emerge, with differences in $\mathrm{N}_{2} \mathrm{O}$ concentrations in the ACW and PSW likely related to contrasting productivity and carbon export in these waters [e.g., Naidu et al., 2004]. Some of the lowest $\mathrm{N}_{2} \mathrm{O}$ concentrations along the transect were measured in ACW waters that were characterized by low nutrient concentrations and biological productivity (stations UTN-1, SEC-5, SEC-7, Figure 4). This low productivity results in lower carbon fluxes [Naidu et al., 2004], limiting denitrification and nitrification sources of $\mathrm{N}_{2} \mathrm{O}$. In contrast, the PSW-influenced central channel waters were characterized by higher nutrient concentrations and phytoplankton biomass, and high benthic oxygen consumption has been previously measured in this region [Grebmeier, 1993]. As expected, we observed higher $\mathrm{N}_{2} \mathrm{O}$ concentrations in the central channel (stations UTN-3, UTN-7, SEC-1, SEC-3). 


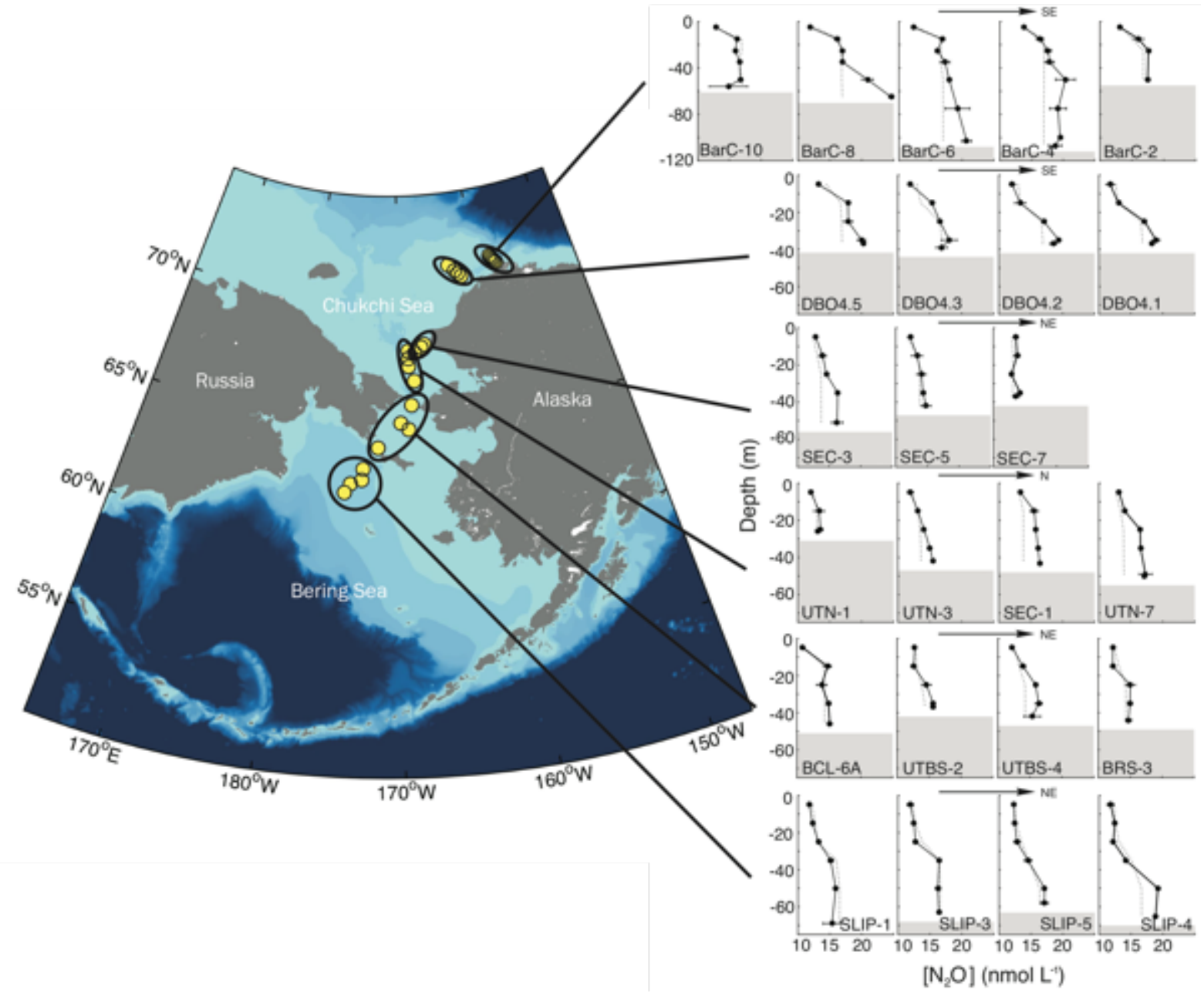

Figure 4: Map and corresponding $\mathrm{N}_{2} \mathrm{O}$ depth profiles in the Bering and Chukchi Seas. Black filled circles denote a measurement, while the error bars represent the standard deviation of the duplicate samples. The grey dotted line is the atmospheric equilibrium concentration.

The highest $\mathrm{N}_{2} \mathrm{O}$ concentrations along the entire transect $\left(24.6 \mathrm{nmol} / \mathrm{L} \mathrm{N}_{2} \mathrm{O}\right.$ ) were measured at the northernmost stations (BarC-8) in the remnant PWW at a depth of $65 \mathrm{~m}$. On average, the $\mathrm{N}_{2} \mathrm{O}$ concentration below the shallow (5-15m) fresher water surface layer was $18.0 \mathrm{nmol} / \mathrm{L}$, representing an increase of $3.6 \mathrm{nmol} / \mathrm{L}$ relative to the PSW. Similarly, the accumulation of $\mathrm{N}_{2} \mathrm{O}$ in the bottom waters of the northward-flowing Bering and Chukchi Seas was also observed by Hirota et al. (2009). To further illustrate this latitudinal gradient in $\mathrm{N}_{2} \mathrm{O}$ concentration, Fig. 5 shows a latitude-depth contour plot highlighting the strong north-south $\mathrm{N}_{2} \mathrm{O}$ gradient along the 26.5 isopycnal ( $\mathrm{S} \approx 33$ ) (Figure 5). This pattern may reflect the accumulation of $\mathrm{N}_{2} \mathrm{O}$ in the bottom waters as they flow over the Chukchi Shelf. 
An additional explanation for the high $\mathrm{N}_{2} \mathrm{O}$ concentrations is the slower circulation rates of PWW over the shelf [Woodgate et al., 2005a], which would result in an increased time for $\mathrm{N}_{2} \mathrm{O}$ accumulation in the winter water, as denitrification rates remain constant throughout the year [Devol et al., 1997; Chang and Devol, 2009]. Furthermore, brine rejection during ice growth in the winter generates convective overturning, stirring the sediments and likely adding $\mathrm{N}_{2} \mathrm{O}$ to the PWW [Pickart et al., 2016].

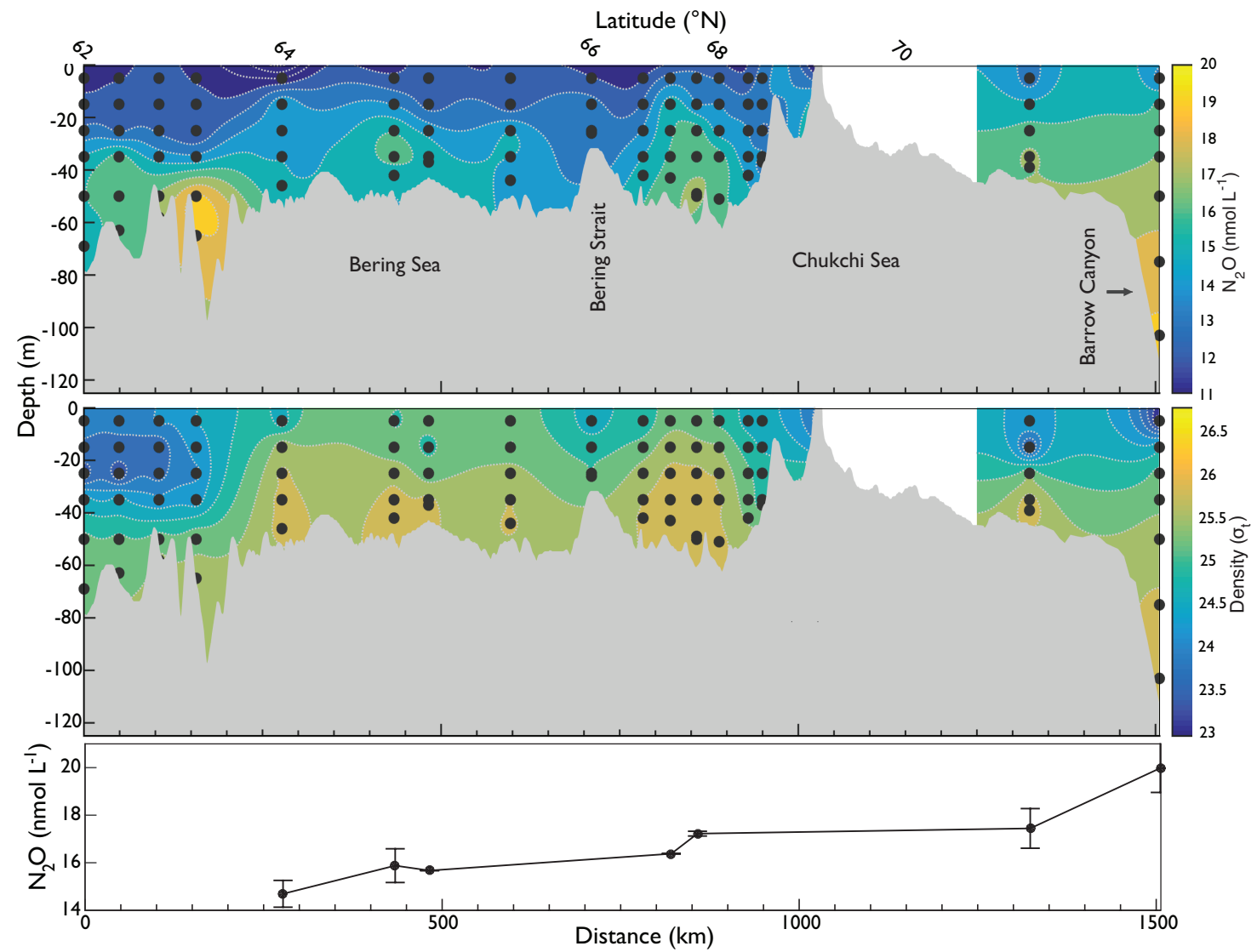

Figure 5: Nitrous oxide and density contour plots. The top two panels show the distribution of $\mathrm{N}_{2} \mathrm{O}$ and density along a $\sim 1500 \mathrm{~km}$ transect from the Bering to the Beaufort Sea (black line on Fig. 1), respectively. The bottom panel shows the mean concentration of $\mathrm{N}_{2} \mathrm{O}$ on the 26.5 density surface, illustrating the accumulation of $\mathrm{N}_{2} \mathrm{O}$ along this isopycnal.

To determine the sources of $\mathrm{N}_{2} \mathrm{O}$ in the Bering and Chukchi Sea regions, we examined the relationship between $\mathrm{N}_{2} \mathrm{O}$ concentrations and other hydrographic variables. Water column $\mathrm{N}_{2} \mathrm{O}$ production in these shallow regions may be limited, as nitrifying bacteria are potentially light-inhibited [ Ward, 2008], and water column oxygen concentrations are too high for denitrification. Rather, sedimentary processes likely represent the predominant $\mathrm{N}_{2} \mathrm{O}$ source to the water column, and this is consistent with the observation of maximum 
concentrations in the bottom waters (Figure 4). Previous studies have attributed the high $\mathrm{N}_{2} \mathrm{O}$ concentrations on the Bering and Chukchi Sea shelves to denitrification in the sediments [Hirota et al., 2009]. Indeed, we observed a negative correlation between $\Delta \mathrm{N}_{2} \mathrm{O}$ and $\mathrm{N}^{*}$ (Figure 6) in this region, providing evidence that denitrification is a source of $\mathrm{N}_{2} \mathrm{O}$ to the water column. Although the relationship between $\mathrm{N}^{*}$ and $\mathrm{N}_{2} \mathrm{O}$ is statistically significant $(\mathrm{p}<0.0001)$, it exhibits significant scatter $\left(\mathrm{r}^{2}=0.18\right)$. Some of this variability is likely attributable to the influence of other nitrogen cycling processes in $\mathrm{N}_{2} \mathrm{O}$ production. Recently, nitrification-denitrification coupling has been identified as an important process on the Bering and Chukchi Sea shelves [Granger et al., 2011; Horak et al., 2013; Brown et al., 2015]. This pairing has been shown to be an important mechanism in $\mathrm{N}_{2} \mathrm{O}$ production [Naqvi et al., 1998]. Typically, the correlation of $\Delta \mathrm{N}_{2} \mathrm{O}$ with $\mathrm{AOU}$ is used to determine if nitrification is a source of $\mathrm{N}_{2} \mathrm{O}$. In our data set, we found no significant relationship between the two variables. This result may be attributable to large differences between the oxygen concentration in the water column $\left(>230 \mu \mathrm{mol} / \mathrm{L} \mathrm{O}_{2}\right)$ compared to the sediments (due to high benthic $\mathrm{O}_{2}$ consumption; Grebmeier et al., [2006b]), such that the water column AOU does not reflect the conditions of $\mathrm{N}_{2} \mathrm{O}$ production. Although we cannot determine the exact mechanism of $\mathrm{N}_{2} \mathrm{O}$ formation, it is apparent that the active nitrogen cycling on these shelves is the predominant source. 


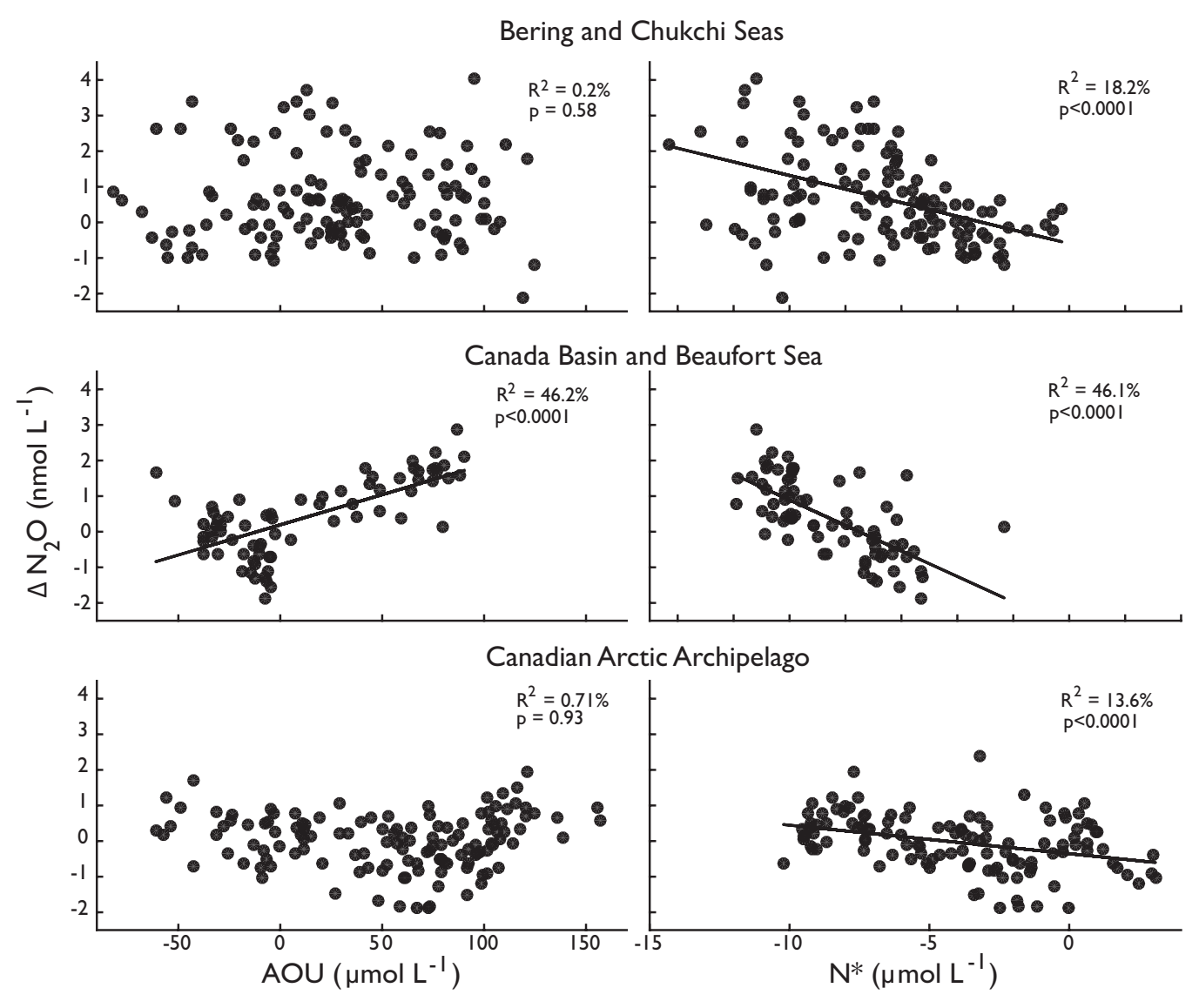

Figure 6: $\Delta \mathrm{N}_{2} \mathrm{O}$ vs. AOU and $\mathrm{N}^{\star}$ plots, broken down by sub-region. Only the Canada Basin UHL is shown in order to better compare the properties of the Pacific water masses between regions. Trend lines are shown where there is a statistically significant regression model $(\mathrm{p}<0.05)$.

\subsection{2 $\mathrm{N}_{2} \mathrm{O}$ in the Canada Basin and Beaufort Sea}

Nearly all the $\mathrm{N}_{2} \mathrm{O}$ profiles in the Canada Basin and Beaufort Sea follow the same pattern, with under-saturated surface water concentrations (91-98\% saturation), increasing to a maximum in PWW, then decreasing to a minimum in the CBDW ( $75 \%$ saturation) (Figure 7). The high $\mathrm{N}_{2} \mathrm{O}$ signature of the Bering and Chukchi seas is transported with the Pacific Winter Water into the Canada Basin and Beaufort Sea. The pronounced $\mathrm{N}_{2} \mathrm{O}$ maximum is tightly constrained to values ranging from 18.5-19.6 $\mathrm{nmol} / \mathrm{L}$, and it occurs at S 33\%o $\left(26.5 \sigma_{\mathrm{t}}\right)$, in the core of the PWW (Figure 3). 

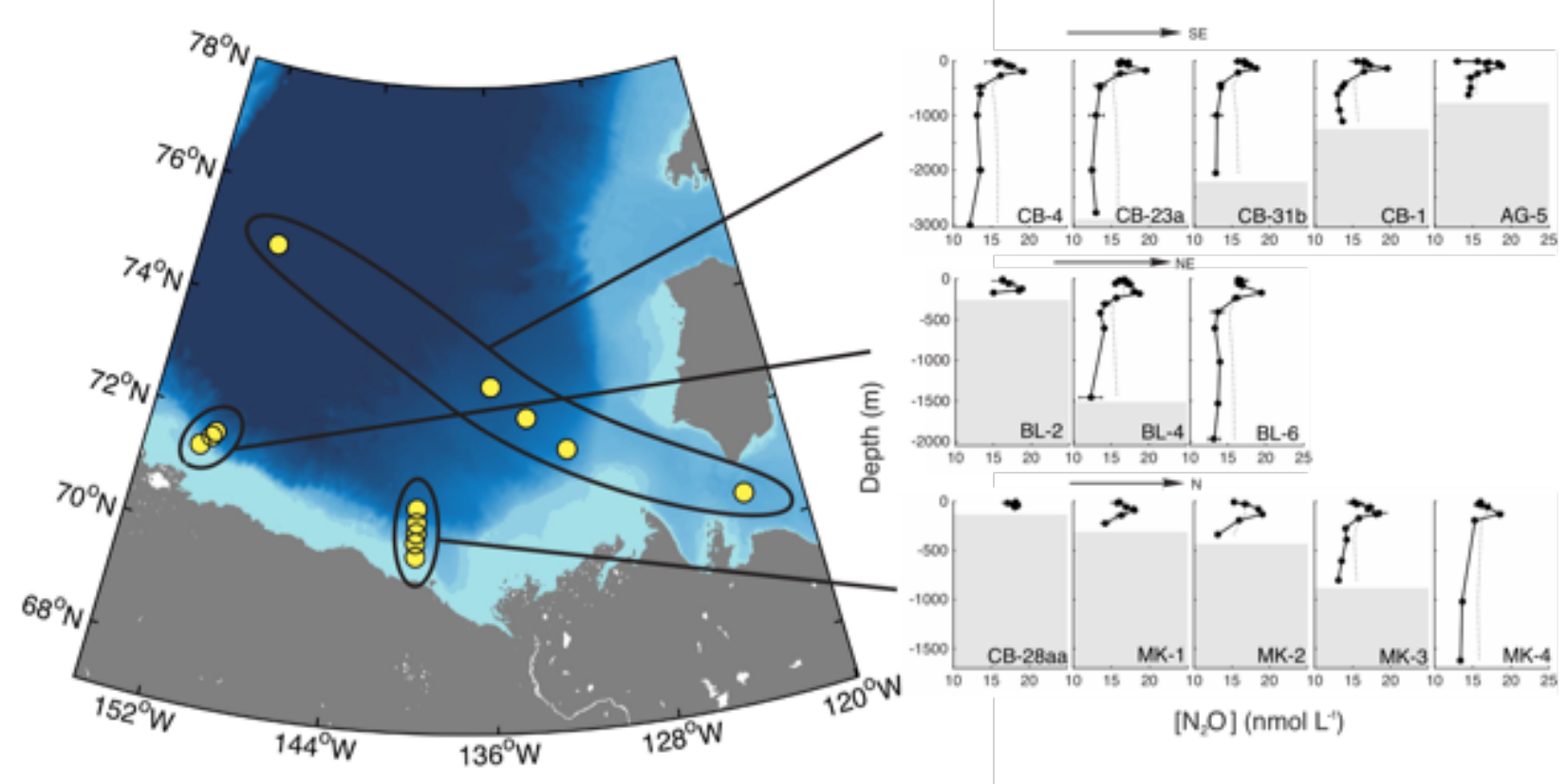

$\left[\mathrm{N}_{2} \mathrm{O}\right]\left(\mathrm{nmol} \mathrm{L}^{-1}\right)$

Figure 7: Map and $\mathrm{N}_{2} \mathrm{O}$ depth profiles in the Canada Basin and Beaufort Sea.

We observed a positive correlation of $\Delta \mathrm{N}_{2} \mathrm{O}$ and $\mathrm{AOU}$ in the Canada Basin samples (Figure 6). In previous studies, this relationship has been taken as evidence of a primary nitrification source for $\mathrm{N}_{2} \mathrm{O}$ in seawater [Nevison et al., 1995]. However, several lines of evidence suggest that the nitrification is only a minor source of $\mathrm{N}_{2} \mathrm{O}$ in the Canada Basin. Based on the slope of the AOU vs. $\Delta \mathrm{N}_{2} \mathrm{O}$ in the UHL of the Canada Basin (40-200m), we calculate $0.016 \mathrm{nmol}$ of $\mathrm{N}_{2} \mathrm{O}$ produced for every $\mu$ mol of $\mathrm{O}_{2}$ consumed. Assuming Redfield stoichiometry, with $17 \%$ of oxygen consumption attributed to $\mathrm{NH}_{4}{ }^{+}$oxidation [Ward, 2008], we derive an $\mathrm{N}_{2} \mathrm{O}$ yield from nitrification of $0.01 \%$. This is value falls within the range previously observed for waters of the Subarctic Pacific Ocean (0.004-0.028\%; [Yoshida et al., 1989; Grundle et al., 2012]). Previous studies have reported a $\sim 1.4 \mu \mathrm{mol} / \mathrm{L}$ difference between the $\mathrm{NH}_{4}{ }^{+}$concentration on the Chukchi shelf and that in the Canada Basin [Zhang et al., 2015]. The nitrification of $1.4 \mu \mathrm{mol} / \mathrm{L} \mathrm{NH}_{4}{ }^{+}$would therefore produce $0.14 \mathrm{nmol} / \mathrm{L} \mathrm{N}_{2} \mathrm{O}$, which represents approximately $7 \%$ of the observed $\mathrm{N}_{2} \mathrm{O}$ surplus in the Canada Basin PWW ( 2.0 nmol/L). Even assuming nitrification of up to $6 \mu \mathrm{mol} / \mathrm{L} \mathrm{NH}_{4}^{+}$ (the highest concentration of $\mathrm{NH}_{4}{ }^{+}$documented on the Chukchi shelf [Brown et al., 2015]), only $\sim 0.6 \mathrm{nmol} / \mathrm{L} \mathrm{N}_{2} \mathrm{O}$ would be produced. This suggests that the high $\mathrm{N}_{2} \mathrm{O}$ signature in the Canada Basin is set by processes occurring in the Bering and Chukchi shelves, with 
only a negligible amount added by in situ water column nitrification within the Canada Basin. This notion is supported by the negative correlation of $\Delta \mathrm{N}_{2} \mathrm{O}$ with $\mathrm{N}^{\star}$ in the UHL of the Canada Basin, which implies that denitrification is a major source of $\mathrm{N}_{2} \mathrm{O}$ (Figure 6), similar to the relationship we observed on the Bering and Chukchi Sea shelves. Previous authors have raised concerns about the use of $\mathrm{N}_{2} \mathrm{O}-\mathrm{AOU}$ relationships as an indicator of nitrification as a primary $\mathrm{N}_{2} \mathrm{O}$ source [Nevison et al., 2003; Bange, 2008]. In particular, Yamagishi et al. [2005] showed that denitrification-sourced $\mathrm{N}_{2} \mathrm{O}$ assumed a linear relationship with AOU when diffusing into deep waters,. This implies that a linear relationship between $\mathrm{N}_{2} \mathrm{O}$ and $\mathrm{AOU}$ can result from water mass mixing rather than remineralization processes.

The Beaufort Sea is strongly influenced by the upper layers of the Canada Basin. Our observations point to physical processes, rather than microbial ones, as key determinants of $\mathrm{N}_{2} \mathrm{O}$ distributions. As an example of this, our results demonstrate the regional importance of upwelling on $\mathrm{N}_{2} \mathrm{O}$ distributions. This was especially evident at $\mathrm{CB} 28 \mathrm{aa}$, where PWW from MK1 upwelled onto the shelf, replacing the water at this shallow shelf station with PWW and yielding high $\mathrm{N}_{2} \mathrm{O}$ concentrations in shallow $(<60 \mathrm{~m})$ waters (Figure 7).

Deep Canada Basin waters contain low and relatively constant concentrations of $\mathrm{N}_{2} \mathrm{O}$, with an average value of $13 \mathrm{nmol} / \mathrm{L}$ (80\% saturation). Our observations are in good agreement with those of Zhan et al. [2015], who observed an average concentration of 12.5 $\mathrm{nmol} / \mathrm{L}$ in these waters. These authors attributed the large apparent under-saturation to the historical characteristics of the deep water. Deep Canada Basin waters were last exposed to the atmosphere $\sim 450$ years ago [Schlosser et al., 1997], when atmospheric $\mathrm{N}_{2} \mathrm{O}$ concentrations were $16 \%$ lower than modern values [Flückiger et al., 1999]. Using the equation by Weiss and Price [1980], and assuming an atmospheric mixing ratio of $270 \mathrm{ppb}$ for the year 1700 [Flückiger et al., 1999], the equilibrium concentration at that time was $\sim 13 \mathrm{nmol} / \mathrm{L}$, which is equal to our average concentration in the deep Canada Basin waters. This provides an explanation for the strong apparent under-saturation of these waters when expressed relative to modern equilibrium values. 


\subsection{3 $\mathrm{N}_{2} \mathrm{O}$ in the Canadian Arctic Archipelago}

Surface concentrations of $\mathrm{N}_{2} \mathrm{O}$ in the CAA varied from $13.1 \mathrm{nmol} / \mathrm{L}$ (95\% saturation) to $17.8 \mathrm{nmol} / \mathrm{L}$ (110\% saturation). Concentrations greater than atmospheric equilibrium were generally observed in association with ice cover (CAA-4, CAA-7, VS), and a maximum of 16.0 - $18.5 \mathrm{nmol} / \mathrm{L}$ was observed in the Pacific Winter Water $\left(26.5 \sigma_{\mathrm{t}}\right)$ (Figure 8). These maximum concentrations were lower than those measured in the Canada Basin. Below the $\mathrm{N}_{2} \mathrm{O}$ maximum, concentrations generally decreased with depth to near atmospheric equilibrium values $(\sim 14.5 \mathrm{nmol} / \mathrm{L})$. We observed a notable decrease in the maximum $\mathrm{N}_{2} \mathrm{O}$ concentration east of the Amundsen Gulf, with the exception of stations AN-312 and AN-314, which were too shallow to contain PWW. Similar to the other regions, we observed a negative correlation between $\Delta \mathrm{N}_{2} \mathrm{O}$ and $\mathrm{N}^{\star}$ (Figure 6), implying that the $\mathrm{N}_{2} \mathrm{O}$ maximum in the CAA is originates from the Pacific shelves. This result suggests that the $\mathrm{N}_{2} \mathrm{O}$ signal is being transported thousands of kilometers across the Arctic Ocean along the $26.5 \sigma_{\mathrm{t}}$ isopycnal, until it is attenuated in the CAA (Figure 3). The reduction in $\mathrm{N}_{2} \mathrm{O}$ concentrations in the CAA can be attributed to sea-air flux (see below), and the mixing of the PW with low $\mathrm{N}_{2} \mathrm{O}$ sea ice melt-water and/or river water.

In Baffin Bay, $\mathrm{N}_{2} \mathrm{O}$ concentrations were close to atmospheric equilibrium values through much of the water column, increasing with depth to a sub-surface maximum at $1500 \mathrm{~m}$ of $18.0 \mathrm{nmol} / \mathrm{L}$ (115\% saturation) (Figure 8). A similar deep $\mathrm{N}_{2} \mathrm{O}$ maximum in Baffin Bay was reported by Kitidis et al. [2010], who attributed this feature to sedimentary denitrification in the sediments just off of Greenland [Rysgaard et al., 2004]. 


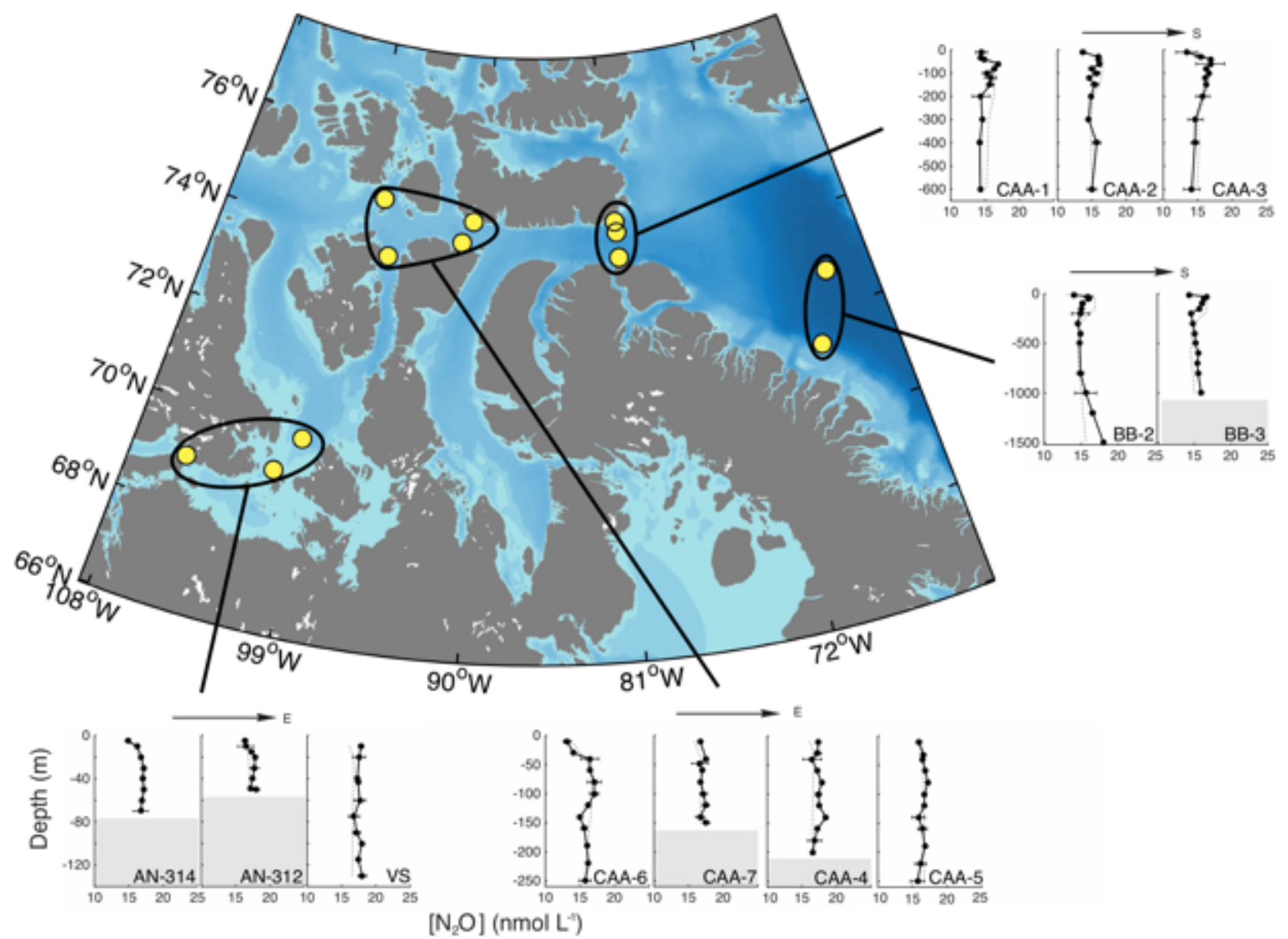

Figure 8: Map and depth profiles of $\mathrm{N}_{2} \mathrm{O}$ in the CAA.

\subsection{METHANE}

Across our entire sampling transect, $\mathrm{CH}_{4}$ concentrations varied greatly, ranging from 0.7 to $30.5 \mathrm{nmol} / \mathrm{L}$, corresponding to percent saturation of $30 \%$ to $800 \%$. We observed the highest concentrations of $\mathrm{CH}_{4}$ in the remnant PWW of the northern Chukchi Sea (Figure 9). Unlike $\mathrm{N}_{2} \mathrm{O}, \mathrm{CH}_{4}$ was oxidized relatively rapidly in the water column, limiting the transport of high $\mathrm{CH}_{4}$ concentrations in eastward flowing waters (Figure 3). As a result, the high $\mathrm{CH}_{4}$ concentrations present in the Chukchi Sea, at a density surface of $26.5 \sigma_{\mathrm{t}}$, were not observed in either the Beaufort Sea or CAA region. In the Canada Basin, a ubiquitous and stable maximum in the UHL associated with the Pacific Summer Water (PSW) was measured at $25.5 \sigma_{\mathrm{t}}$ (Figure 3). By contrast, $\mathrm{CH}_{4}$ concentrations below the UHL varied 
greatly, ranging from 1 to $24 \mathrm{nmol} / \mathrm{L} \cdot \mathrm{CH}_{4}$ concentrations in the Canadian Arctic Archipelago (CAA) showed large surface maxima, up to $15.0 \mathrm{nmol} / \mathrm{L}$, and decreasing concentrations with depth to near atmospheric equilibrium values. This spatial and temporal variation underscores the ephemeral nature of $\mathrm{CH}_{4}$ sources and sinks.

\subsection{1 $\mathrm{CH}_{4}$ in the Bering and Chukchi Seas}

Methane concentrations in the Bering and Chukchi Seas were almost ubiquitously supersaturated throughout the water column. Concentrations ranged from slightly greater than atmospheric equilibrium in the surface of the Bering Sea $(\sim 3 \mathrm{nmol} / \mathrm{L})$ to values close to $800 \%$ saturation $(30.5 \mathrm{nmol} / \mathrm{L})$ in the northern Chukchi Sea (Figure 9). $\mathrm{CH}_{4}$ distributions appeared to be more influenced by local sources than $\mathrm{N}_{2} \mathrm{O}$, including potential sources from rivers feeding into the ACW, and sediment-derived $\mathrm{CH}_{4}$ in the northern Chukchi Sea water column. Surface water $\mathrm{CH}_{4}$ concentrations were frequently supersaturated, averaging $4.8 \mathrm{nmol} / \mathrm{L}$ (150\% saturation). No spatial concentration gradient was discernable within our study area. The surface water $\mathrm{CH}_{4}$ concentrations we measured were lower than the average surface $\mathrm{CH}_{4}$ concentrations previously reported for the Chukchi Sea by Kosmach et al. [2015] and Savvichev et al. [2007] (8.1 nmol/L and 11.2 $\mathrm{nmol} / \mathrm{L}$, respectively). These previous studies sampling further west in the Chukchi Sea, where higher $\mathrm{CH}_{4}$ concentrations have previously been reported relative to the eastern sections [Savvichev et al., 2007]. 


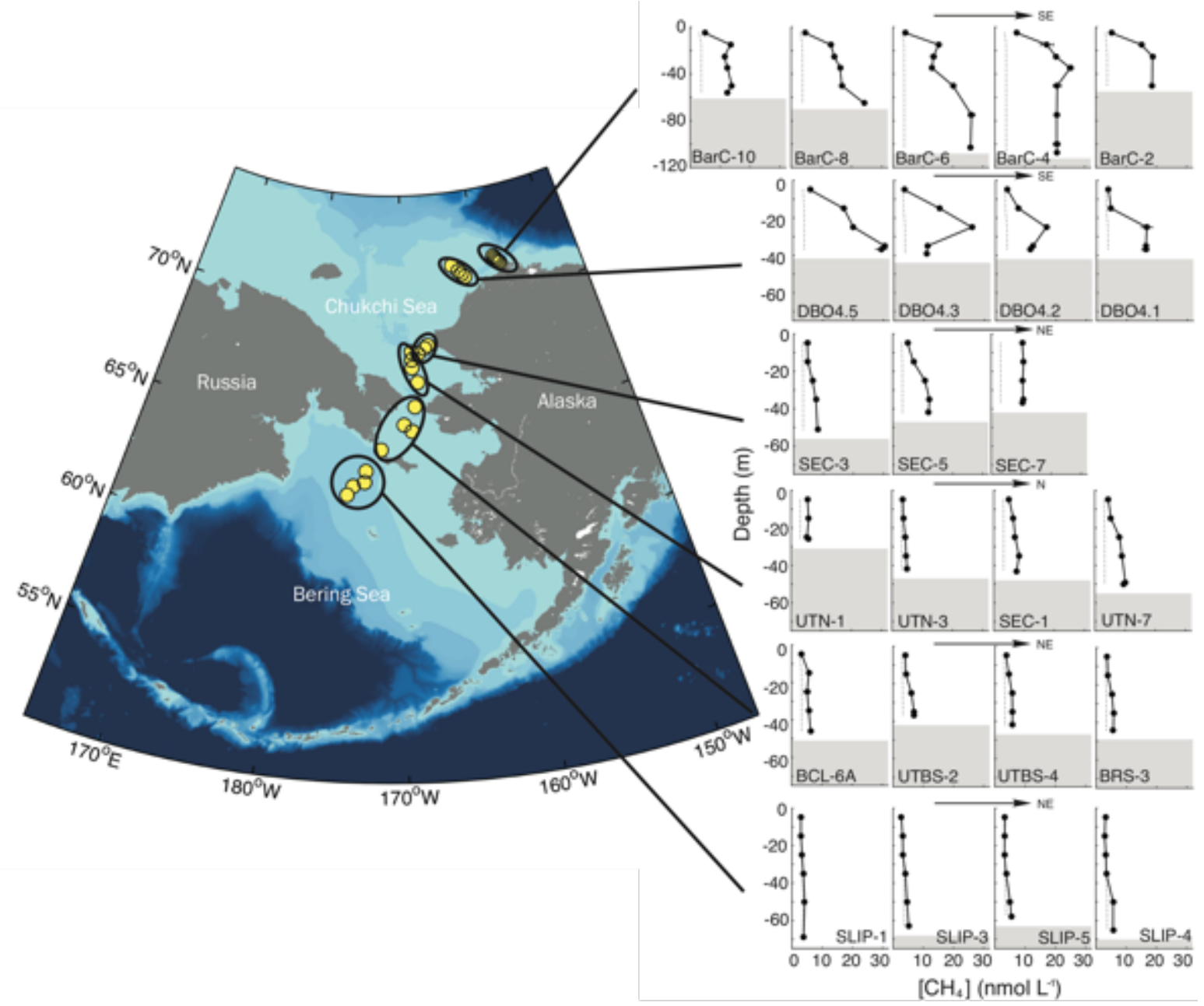

Figure 9: Map and depth profiles of $\mathrm{CH}_{4}$ in the Bering and Chukchi Seas

Below the surface mixed layer $\mathrm{CH}_{4}$ concentrations increased considerably from the northern Bering Sea (mean $\sim 5 \mathrm{nmol} / \mathrm{L}$ ) to the northern Chukchi Sea (mean $\sim 17 \mathrm{nmol} / \mathrm{L}$ ) (Figure 10). Our measurements from just south of the Bering Strait contained increasing concentrations of $\mathrm{CH}_{4}$ with depth (up to $\sim 7.0 \mathrm{nmol} / \mathrm{L}, 210 \%$ saturation). In the southern Chukchi Sea, elevated $\mathrm{CH}_{4}$ concentrations (mean $8.7 \mathrm{nM}$, range: 5.3-12.3 nmol/L) were observed in the ACW (stations UTN-1, SEC-5, SEC-7) while lower $\mathrm{CH}_{4}$ concentrations (mean $6.3 \mathrm{nmol} / \mathrm{L}$, range: $3.7-10.1 \mathrm{nmol} / \mathrm{L}$ ) were measured in the more $\mathrm{PSW}$-influenced western stations (UTN-3, UTN-7, SEC-1, SEC-3). This is somewhat surprising given that rates of methanogenesis in the sediments of the southern central Chukchi Sea have been found to be five times greater than those near the Alaskan Coast [Savvichev et al., 2007]. Instead, the greater concentrations of $\mathrm{CH}_{4}$ in the ACW may reflect the high $\mathrm{CH}_{4}$ 
concentrations associated with river inputs into the ACW, which results from the methanogenesis of organic material in degrading permafrost [Striegl et al., 2012]. This implies that methanogenesis in oceanic sediments is perhaps only minor compared to the contribution of $\mathrm{CH}_{4}$ by rivers.

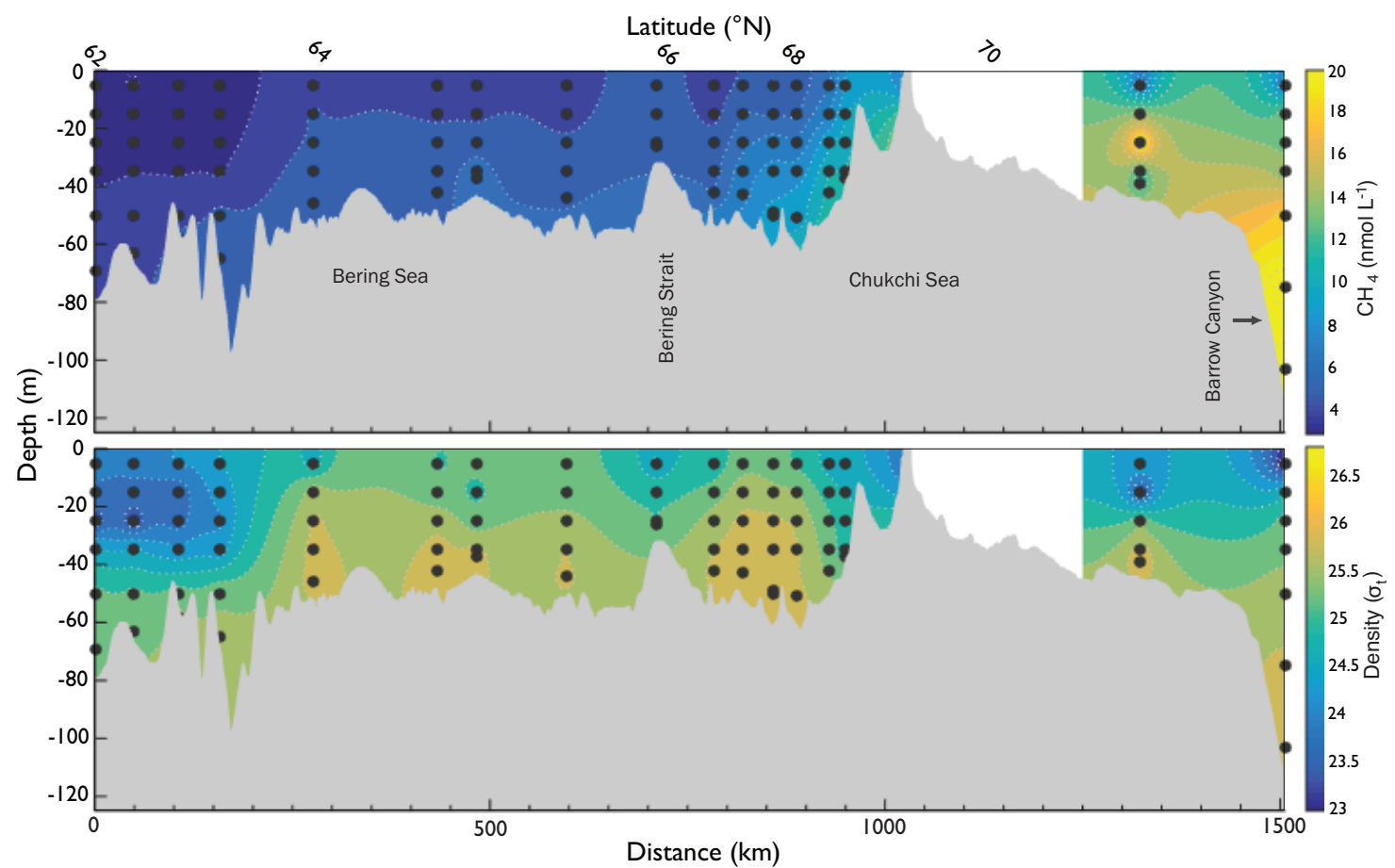

Figure 10: Methane and density contour plots. The top panel shows the distribution of $\mathrm{CH}_{4}$ along a $\sim 1500 \mathrm{~km}$ transect from the Bering to the Beaufort Sea (black line on Fig. 1). The bottom panel shows the density distribution along the same transect.

The highest dissolved $\mathrm{CH}_{4}$ concentrations in the study area were observed in the sea ice-influenced remnant PWW in the Northern Chukchi Sea $(30.6 \mathrm{nmol} / \mathrm{L})$ near the sediments. Previous work has demonstrated high concentrations of $\mathrm{CH}_{4}$, averaging 2200 $\mathrm{nmol} / \mathrm{L}$, in the upper $2 \mathrm{~cm}$ of sediments of the northern Chukchi Sea (Lapham et al., submitted). Brine rejection, as a result of sea ice growth, causes convective overturning of the water column and mixes the sediments, releasing regenerated nutrients and gases into the PWW [Pickart et al., 2016]. As this process only occurs in the winter, it may account for the higher $\mathrm{CH}_{4}$ concentrations in the PWW compared to the PSW.

The origin of seafloor $\mathrm{CH}_{4}$ sources is unclear. As this area does not contain subsea permafrost or gas hydrates [Ruppel, 2015], it is uncertain whether the elevated $\mathrm{CH}_{4}$ signature results from methanogenesis in the sediments or perhaps upward migration of 
thermogenic gas. Rates of methanogenesis of up to $67 \mu \mathrm{mol} \mathrm{m} \mathrm{m}^{-2} \mathrm{~d}^{-1}$ have been measured in the sediments of the Chukchi Sea [Savvichev et al., 2007], implying that this may be a major source of the water column $\mathrm{CH}_{4}$. This area is also in the Chukchi Sea Oil and Gas Lease Sale No. 193, suggesting likely geologic gas deposits.

In addition to the elevated $\mathrm{CH}_{4}$ concentrations in bottom waters of the Chukchi Sea, we also observed $\mathrm{CH}_{4}$ maxima within the upper water column at a few stations (Figure 9) (DBO4.3, DBO4.2, BarC-10, BarC-6, BarC-4). These signatures may be due to in situ methane production within the water column. The most likely processes are methanogenesis in anoxic microenvironments [de Angelis and Lee, 1994; Holmes et al., 2000] or the cleavage of methane from DMSP [Damm et al., 2010]. The cleavage of methyl groups from methanophosphates is unlikely in this case because this region is not phosphate limited [Karl et al., 2008]. Methane has been found to be produced in the ocean where suspended sediments accumulate, presumably in the anaerobic niches provided by these particles [Holmes et al., 2000]. However, we did not find any relationship between the transmissivity of the water column (a proxy for suspended particle loads) and $\mathrm{CH}_{4}$ concentrations. The second possible pathway is the bacterial metabolism of DMSP, a compound produced by phytoplankton, producing precursors for methane formation. A methyl group may be cleaved when bacterioplankton use DMSP as a source of carbon, which occurs predominantly when they are nitrate-limited [Kiene et al., 2000; Damm et al., 2010]. Indeed, we did observe see some co-occurrence of high $\mathrm{CH}_{4}$ with high chlorophyll in this region (Figure 13), implying a potential phytoplankton-derived source of DMSP, could stimulate $\mathrm{CH}_{4}$ release during bacterial DMSP metabolism. In the absence of subsurface DMSP data for this region, we cannot conclusively link DMSP metabolism to $\mathrm{CH}_{4}$ production.

\subsubsection{Stable isotopic composition of $\mathrm{CH}_{4}$ in the Bering and Chukchi Seas}

The large range of our $\mathrm{CH}_{4}$ concentrations in our data suggests that sources of $\mathrm{CH}_{4}$ are variable, and processes that both consume and produce $\mathrm{CH}_{4}$ are pervasive. We used the stable isotope composition of $\mathrm{CH}_{4}$ to provide insight into $\mathrm{CH}_{4}$ cycling in the water column. Some of the lightest $\partial^{13} \mathrm{C}_{\mathrm{CH} 4}$ values $(\sim-41.5 \%$ ) were found in the bottom waters of the northern Chukchi Sea, associated with high concentrations of $\mathrm{CH}_{4}$ (up to $31 \mathrm{nmol} / \mathrm{L}$ ). This 
$-41.5 \%$ minimum is indicative of a more recent source. Although it is relatively heavy for methane produced by microbial methanogenesis (normally considered <-50\%o [Whiticar, 1999]), this may reflect the oxidation of biogenic methane within the sediments and the water column. Biological oxidation preferentially uses ${ }^{12} \mathrm{C}_{\mathrm{CH} 4}$, causing the $\partial^{13} \mathrm{C}_{\mathrm{CH} 4}$ value to increase.

Carbon isotope ratios of $\mathrm{CH}_{4}$ can also allow us to differentiate oxidation and dilution processes in the water column. We calculated a Rayleigh distillation model using the equation by [Coleman et al., 1981]: $\delta^{13} C_{t}=1000 \times\left(\frac{1}{\alpha}-1\right) \times \ln (f)+\delta^{13} C_{0}$. The starting stable isotope composition $\left(\partial^{13} \mathrm{C}_{0}\right)$ is $-40 \%$, and $f$ is the fraction of the residual methane remaining $($ initial $=31 \mathrm{nmol} / \mathrm{L})($ Figure 11$)$. The calculated oxidation curve has a kinetic isotope fractionation factor $(\alpha)$ of 1.002 , which is in the range of expected values for oxidation processes [Whiticar and Faber, 1986]. Samples with high $\mathrm{CH}_{4}$ concentrations have low $\partial^{13} \mathrm{C}_{\mathrm{CH} 4}$ values, while samples with low $\mathrm{CH}_{4}$ concentrations have high $\partial^{13} \mathrm{C}_{\mathrm{CH} 4}$ values due to the enrichment of ${ }^{13} \mathrm{C}$ during oxidation. Slight deviations from the oxidative curve are expected, as the initial concentration and stable isotope composition of the $\mathrm{CH}_{4}$ will not be identical everywhere. As the measurements follow the oxidation curve, they are not considerably altered by dilution which would cause lower $\mathrm{CH}_{4}$ concentrations to also have low $\partial^{13} \mathrm{C}_{\mathrm{CH}}$ values. This affirms that oxidation is the main sink for $\mathrm{CH}_{4}$ in the water column.

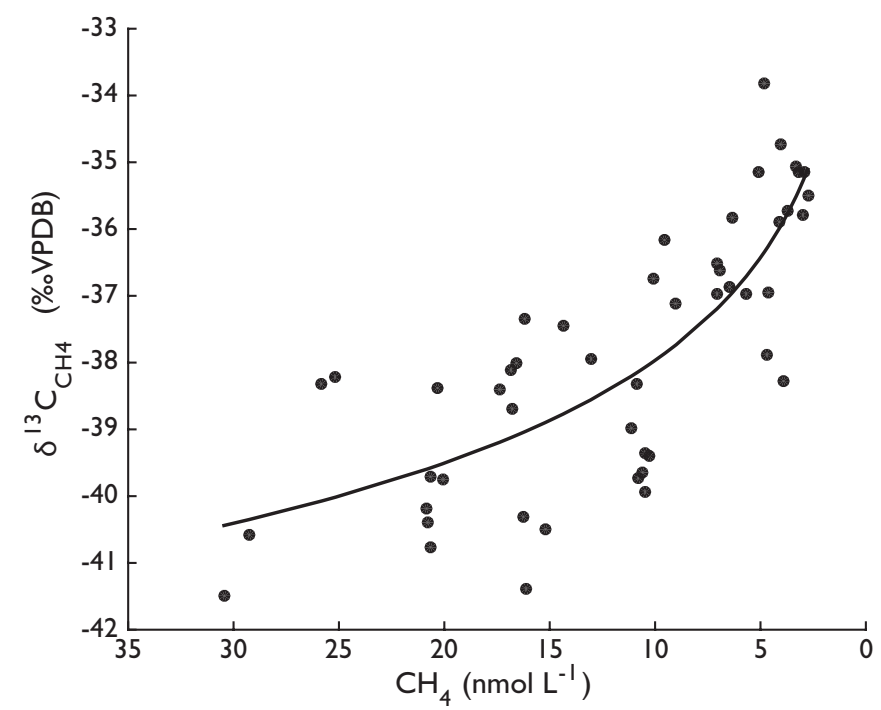

Figure 11: Oxidation curve calculated using a Rayleigh distillation model with an initial concentration of $31 \mathrm{nmol} / \mathrm{L}$, a $\partial^{13} \mathrm{C}_{\mathrm{CH} 4}$ value of $-40 \%$ VPDB, and an isotopic fractionation factor of 1.002 . 


\subsection{2 $\mathrm{CH}_{4}$ in the Canada Basin and Beaufort Sea}

Like $\mathrm{N}_{2} \mathrm{O}$, the $\mathrm{CH}_{4}$ distribution pattern in the Canada Basin and Beaufort Sea was similar at all of the stations. $\mathrm{CH}_{4}$ concentrations were slightly supersaturated in the PML $(<5.3 \mathrm{nmol} / \mathrm{L},<130 \%$ saturation), increasing to a subsurface maximum in the PSW (up to $11.5 \mathrm{nmol} / \mathrm{L}, \sim 300 \%$ saturation), and then declining through the CBIW and CBDW (Figure 13). Surface concentrations were lower than those in the PSW likely due to melt-water dilution in the polar mixed layer and air-sea flux (Section 3.3). The slight surface supersaturation could be attributed to a combination of upward diffusion from the PSW maximum and a sea ice source. Brine channels within sea ice are frequently anaerobic, providing the necessary conditions for anoxic processes such as methanogenesis [Rysgaard et al., 2008]. In the winter, the $\mathrm{CH}_{4}$ is mixed throughout the winter mixed layer with the rejected brine, and as the ice melts in the spring, any remaining brine is released into the surface melt water layer [Damm et al., 2015a]. This process has been recently shown to cause similar surface super-saturation in the central Arctic Ocean [Damm et al., 2015a].

The PSW contained a surprisingly widespread and consistent $\mathrm{CH}_{4}$ maximum (averaging $9.1 \mathrm{nmol} / \mathrm{L}, 250 \%$ saturation) at a density of $25.5 \sigma_{\mathrm{t}}(\mathrm{S}=31.8)$ and associated with the chlorophyll maximum (Figure 13). This peak is surprising because $\mathrm{CH}_{4}$ is normally consumed relatively quickly in oxygenated waters, and should not be produced under aerobic conditions [Reeburgh, 2007]. As discussed above, DMSP metabolism may be a source of water column $\mathrm{CH}_{4}$ production, particularly under $\mathrm{NO}_{3}{ }^{-}$limiting conditions [Damm et al., 2010, 2015b]. This relationship implies that DMSP may be an in-situ source of these high $\mathrm{CH}_{4}$ concentrations, providing an explanation for this ubiquitous signal. 

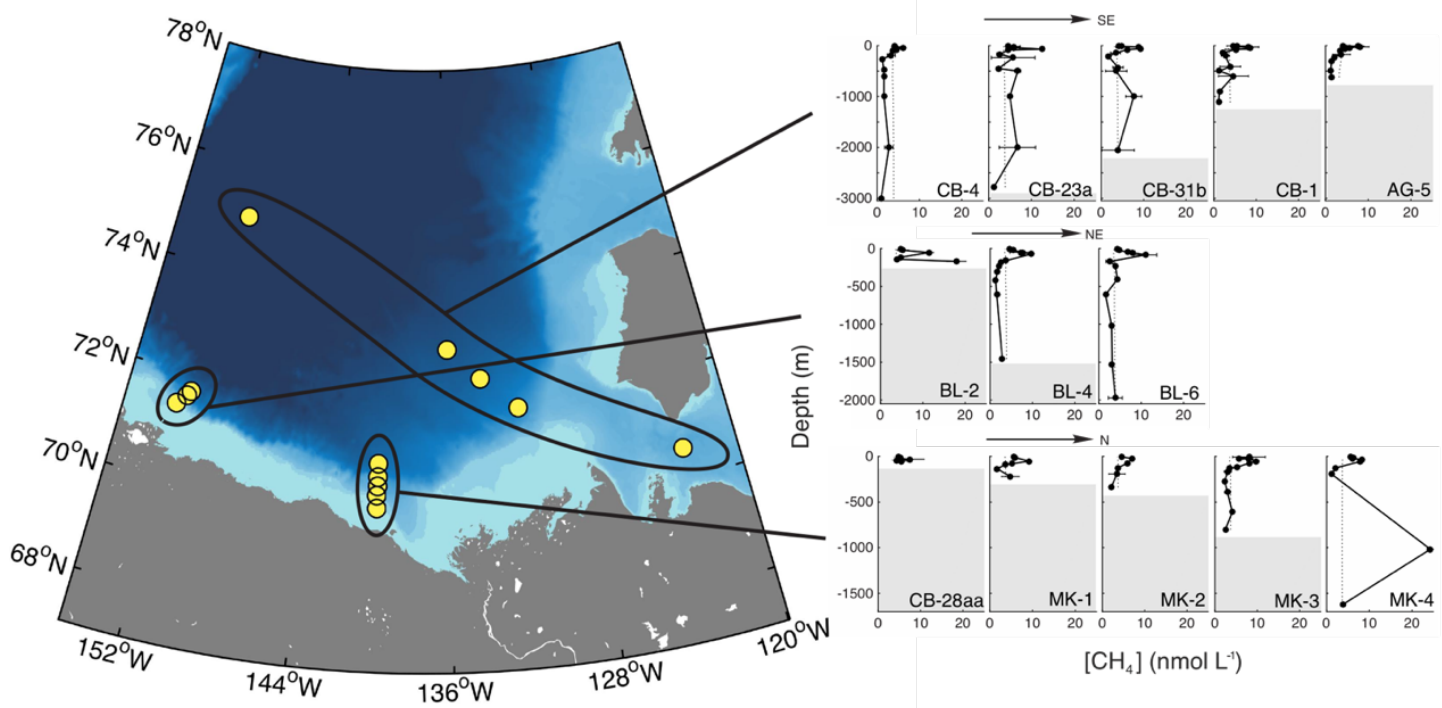

$\left[\mathrm{CH}_{4}\right]\left(\mathrm{nmol} \mathrm{L}^{-1}\right)$

Figure 12: Map and depth profiles of $\mathrm{CH}_{4}$ concentrations in the Canada Basin and Beaufort Sea

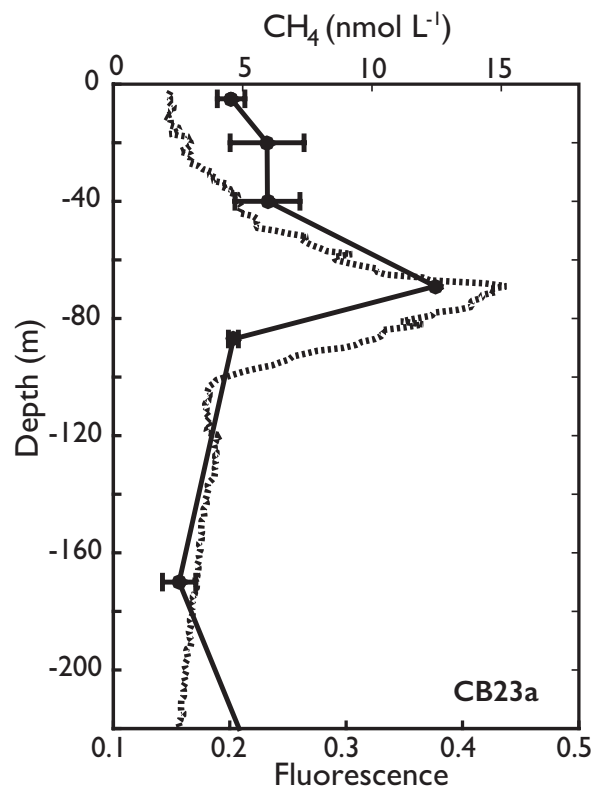

Figure 13: This is a representative depth profile of $\mathrm{CH}_{4}$ and fluorescence, showing the co-occurrence of the $\mathrm{CH}_{4}$ and chlorophyll maxima. Filled black circles denote $\mathrm{CH}_{4}$ concentration and error bars represent the standard deviation of the duplicates. The dotted line is fluorescence.

At depths below $200 \mathrm{~m}$ in the Canada Basin, $\mathrm{CH}_{4}$ concentrations were extremely variable, ranging from $1.0 \mathrm{nmol} / \mathrm{L}$ ( $27 \%$ saturation) to $24.3 \mathrm{nmol} / \mathrm{L}(\sim 700 \%$ saturation), with a median value of $3.1 \mathrm{nmol} / \mathrm{L}$ ( $\sim 90 \%$ saturation) below $1000 \mathrm{~m}$. This under-saturation could reflect lower atmospheric $\mathrm{CH}_{4}$ concentrations at the time of ventilation (as discussed above for $\mathrm{N}_{2} \mathrm{O}$ ), and/or oxidation of $\mathrm{CH}_{4}$ by methanotrophs in the deep water column. Unlike $\mathrm{N}_{2} \mathrm{O}$, the $\mathrm{CH}_{4}$ under-saturation was not consistently observed throughout the 
Canada Basin, making it more difficult to attribute to a particular process. Rather, the large range of $\mathrm{CH}_{4}$ concentrations suggest the importance of ephemeral point sources. Notwithstanding the highly variable nature of $\mathrm{CH}_{4}$ concentrations, we are still able to examine the potential contribution of biological and physical processes to the observed under-saturation at certain stations. The CBDW has been isolated for $\sim 450$ years [Schlosser et al., 1997; Timmermans et al., 2003]. At the time that this water mass was last exposed to the atmosphere, the $\mathrm{CH}_{4}$ mixing ratio was $\sim 675 \mathrm{ppb}$ [Raynaud and Chappellaz, 1993]. Assuming that the temperature and salinity characteristics of this water mass have not been appreciably altered since it left the surface, the predicted equilibrium $\mathrm{CH}_{4}$ would be 1.4 $\mathrm{nmol} / \mathrm{L}$, which is $1.7 \mathrm{nmol} / \mathrm{L}$ lower than our observations. Even if some changes in temperature and salinity did occur, this would only have a small effect on our calculations. For instance, a difference in temperature of $1^{\circ} \mathrm{C}$ would change the solubility of $\mathrm{CH}_{4}$ by less than $0.1 \mathrm{nmol} / \mathrm{L}$, while a salinity change of $1 \%$, would alter $\mathrm{CH}_{4}$ solubility by $\sim 0.03 \mathrm{nmol} / \mathrm{L}$. Our results thus suggest that $\mathrm{CH}_{4}$ has been added to the deep water by other, presumably biological processes. In contrast, the minimum $\mathrm{CH}_{4}$ concentration we measured was only $1.0 \mathrm{nmol} / \mathrm{L}$, which is $0.4 \mathrm{nmol} / \mathrm{L}$ less than the atmospheric equilibrium concentration 450 years ago. This lower value, therefore, can only have been obtained through biological consumption. The lack of persistently high $\mathrm{CH}_{4}$ concentrations in the deep basin thus provides additional evidence for the microbial oxidation in these waters.

In addition to very low $\mathrm{CH}_{4}$ concentrations, we observed more episodic, deeper maxima in the Canada Basin. Two of these $\mathrm{CH}_{4}$ maxima are particularly large and warrant further explanation. There was a maximum on the Beaufort shelf at $170 \mathrm{~m}(18 \mathrm{nmol} / \mathrm{L})$, and just off the slope at $1000 \mathrm{~m}(24 \mathrm{nmol} / \mathrm{L})$. Considering that both of these stations are deeper than the maximum depth of subsea permafrost on the Beaufort shelf $(\sim 120 \mathrm{~m})$, there are three possible sources that may explain these high concentrations: destabilized hydrates on the Beaufort Slope, methanogenesis in sediments, and thermogenic seeps. Gas hydrates are stable only under specific temperatures and pressures and underlie much of the Arctic Ocean below a depth of $\sim 300 \mathrm{~m}$ [Ruppel, 2015]. The temperature of the water on the Beaufort Shelf has changed considerably over the last 60 years, potentially leading to a destabilization of gas hydrates between 300 and $550 \mathrm{~m}$ [Ruppel, 2015]. Indeed, "old" (low ${ }^{14} \mathrm{C}$ ) $\mathrm{CH}_{4}$ has been found in gas vents on the Beaufort shelf, implying that it is sourced from gas 
hydrates [Paull et al., 2011]. Secondly, sedimentary methanogenesis may produce high $\mathrm{CH}_{4}$ concentrations. The maximum in the western Beaufort shelf, which is contrasted by low concentrations on the eastern shelf (mean $=4.1 \mathrm{nmol} / \mathrm{L}$ ), is in agreement with the observations of Coffin et al. [2013], who measured elevated $\mathrm{CH}_{4}$ flux from the sediments to the water column of the western Beaufort Sea (near the BL stations) and low sedimentwater column fluxes in the eastern Beaufort (near the MK stations). This sedimentary $\mathrm{CH}_{4}$ was primarily biogenic, implicating methanogenesis as the dominant $\mathrm{CH}_{4}$ source. Lastly, the entire Canada Basin is underlain by oil and gas deposits [Ruppel, 2015]. Gas may migrate through fractured rock and enter the sediments, and may be released through vents in the sea floor.

\subsection{3 $\mathrm{CH}_{4}$ in the Canadian Arctic Archipelago}

Throughout the Canadian Arctic Archipelago, $\mathrm{CH}_{4}$ concentrations decreased from south (mean $7.3 \mathrm{nmol} / \mathrm{L}$ ) to north (mean $3.8 \mathrm{nmol} / \mathrm{L}$ ). In contrast to the other regions in our study area, we observed extremely high concentrations in surface waters of the CAA, with maximum values in excess of $420 \%$ saturation $(15.3 \mathrm{nmol} / \mathrm{L})$, and decreasing concentrations with depth (Figure 14). This surface maximum was most prominent at the southern stations (AN-314, AN-312, and VS), but was also observed at some of the northern stations (CAA-4 and CAA-7) (Figure 14). Super-saturation of $\mathrm{CH}_{4}$ in surface waters of the CAA was previously observed by Kitidis et al. [2010], who ascribed it to greater ice cover in the CAA limiting sea-air flux. Indeed, we observed high ice cover at many of the stations with elevated surface $\mathrm{CH}_{4}$ concentrations in the CAA. 


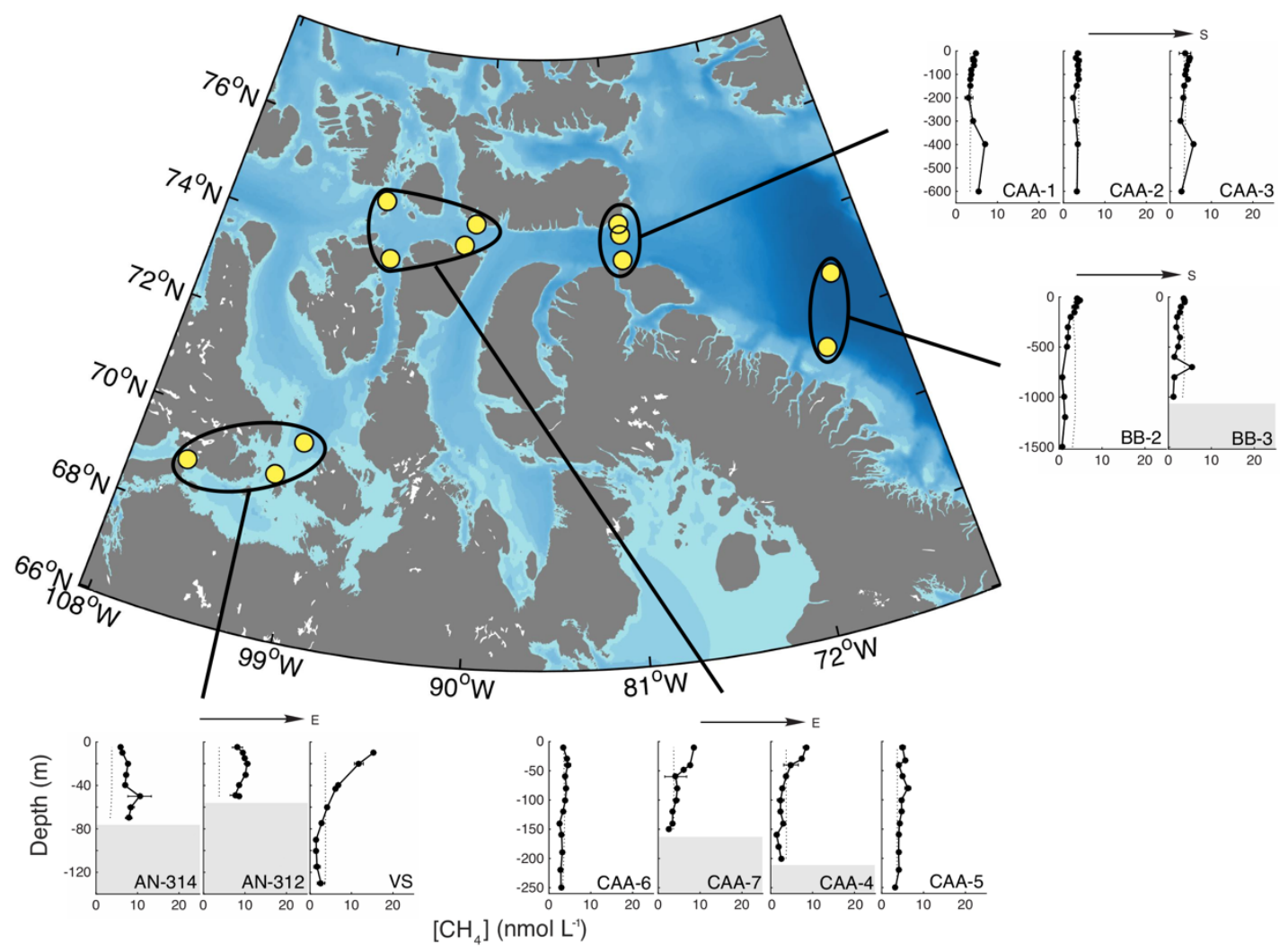

Figure 14: Map and depth profiles of $\mathrm{CH}_{4}$ concentrations in the CAA and Baffin Bay

While increased sea ice cover may contribute to the accumulation of high $\mathrm{CH}_{4}$ in CAA surface waters, ice cover, per se, may also represent a $\mathrm{CH}_{4}$ source. We found a strong negative correlation between $\mathrm{CH}_{4}$ and salinity across all regions we sampled in the CAA (Figure 15), suggesting a freshwater source of $\mathrm{CH}_{4}$ from ice and/or rivers. Rivers could supply $\mathrm{CH}_{4}$ from degrading permafrost or methanogenesis in riverine sediments to the CAA. Sea ice, on the other hand, contains brine channels which can contain high concentrations of $\mathrm{CH}_{4}$ [Damm et al., 2015a]. As the sea ice begins to melt, this brine drains into the surface layer of the ocean. The super-saturation we observe in the surface water at many of the stations in the CAA may be due to this partial melting of sea ice acting both as a $\mathrm{CH}_{4}$ source and a semi-permeable barrier to sea-air flux. 


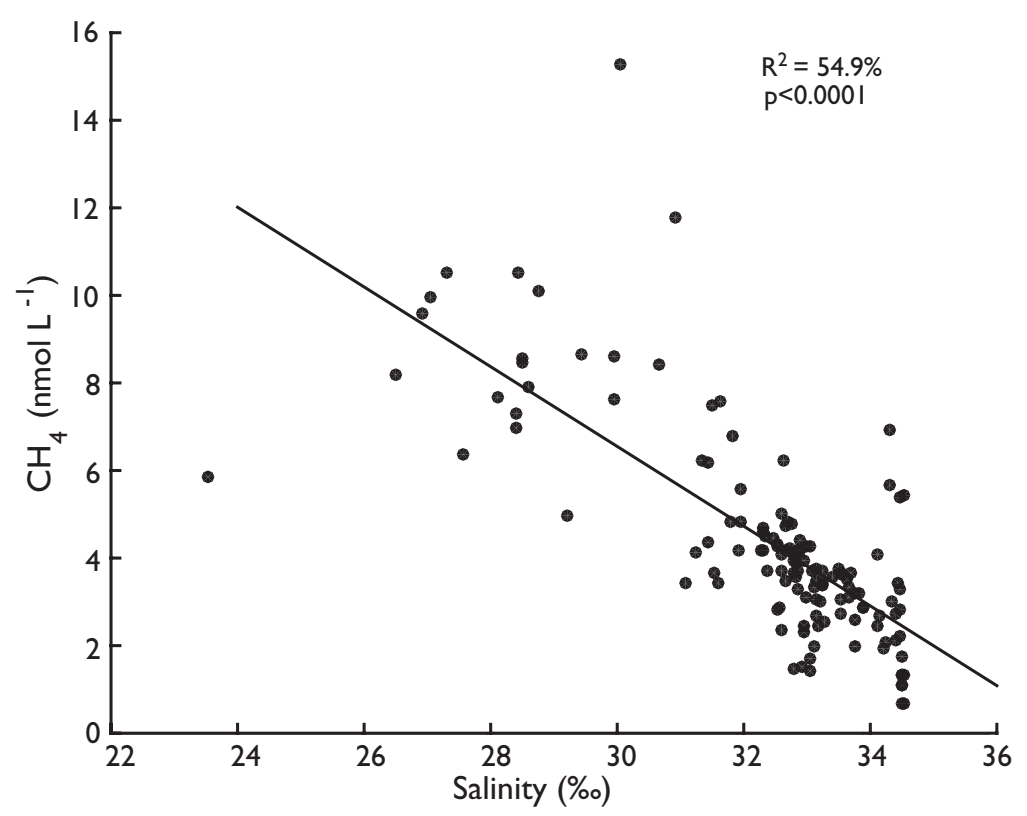

Figure 15: $\mathrm{CH}_{4}$ vs. salinity scatter plot of all samples collected in the CAA and Baffin Bay

East of Lancaster Sound, in Baffin Bay, we observed a modest $\mathrm{CH}_{4}$ maximum (4.7 $\mathrm{nmol} / \mathrm{L}, \sim 130 \%$ saturation) in the upper $50 \mathrm{~m}$ of the water column, with under-saturated concentrations below $100 \mathrm{~m}$, reaching a minimum of $<1 \mathrm{nmol} / \mathrm{L}$. Our results are consistent with those obtained by Punshon et al. [2014] who observed near-equilibrium concentrations in the top $\sim 200 \mathrm{~m}$ of Baffin Bay, with increasing under-saturation in deeper waters. These authors attributed the depth-dependent decrease in $\mathrm{CH}_{4}$ to microbial methane consumption. In contrast with our results, Kitidis et al. [2010] observed high concentrations in the upper $150 \mathrm{~m}$ water column in Baffin Bay, in a depth profile taken in close proximity to our sampling station BB3. The reason for this discrepancy is unclear, but highlights the temporal variability in $\mathrm{CH}_{4}$ concentrations.

\subsection{SEA-AIR $\mathrm{CH}_{4}$ AND $\mathrm{N}_{2} \mathrm{O}$ FLUXES}

Sea-air fluxes of both $\mathrm{CH}_{4}$ and $\mathrm{N}_{2} \mathrm{O}$ across our full survey region were low compared to previous estimates from other Arctic regions, but similar to those from the global ocean (Table 2, Table 3) [Rhee et al., 2009]. Overall, our study area was a source of $\mathrm{CH}_{4}$ with seaair flux averaging $1.3 \mu \mathrm{mol} \mathrm{m}^{-2} \mathrm{~d}^{-1}$ (range $=-0.4$ to $4.9 \mu \mathrm{mol} \mathrm{m}^{-2} \mathrm{~d}^{-1}$ ), and a minor sink for $\mathrm{N}_{2} \mathrm{O}$, with an average sea-air flux of $-0.52 \mu \mathrm{mol} \mathrm{m} \mathrm{d}^{-2}\left(\right.$ range $=-4.1$ to $\left.2.5 \mu \mathrm{mol} \mathrm{m}^{-2} \mathrm{~d}^{-1}\right)$. 
These findings are comparable to typical sea-air fluxes from the world ocean, which range from 0.2-1.5 $\mu \mathrm{mol} \mathrm{m}^{-2} \mathrm{~d}^{-1}$ and 0.3-0.6 $\mu \mathrm{mol} \mathrm{m}^{-2} \mathrm{~d}^{-1}$, for $\mathrm{CH}_{4}$ and $\mathrm{N}_{2} \mathrm{O}$, respectively [Rhee et al., 2009]. At station CB28aa in the eastern Beaufort Sea, we observed high sea-air fluxes of both $\mathrm{CH}_{4}$ and $\mathrm{N}_{2} \mathrm{O}$. At this station, we observed upwelling of deep water onto the shelf (based on its high density) implying that upwelling is a source of these gases to the atmosphere. This observation is in good agreement with previous studies showing the importance of coastal upwelling as a source of elevated $\mathrm{CH}_{4}$ and $\mathrm{N}_{2} \mathrm{O}$ sea-air fluxes in various marine systems [eg., Nevison et al., 2004; Frame et al., 2014; Capelle and Tortell, 2016].

Table 2: Sea-air flux of $\mathrm{N}_{2} \mathrm{O}$

\begin{tabular}{lll}
\hline Region & Sea-air flux $\left(\mu \mathrm{mol} \mathrm{N} \mathrm{O} \mathrm{m}^{-2} \mathrm{~d}^{-1}\right)$ & Reference \\
\hline Bering Sea & $2 \pm 1$ & [Hirota et al., 2009] \\
& $-0.5 \pm 0.5$ & This study \\
Western Chukchi Sea & $12 \pm 9$ & [Hirota et al., 2009] \\
Eastern Chukchi Sea & $-0.4 \pm 0.7$ & This study \\
Canada Basin & $-0.9 \pm 1.4$ & This study \\
CAA & $5 \pm 8$ & [Gagné, 2015] \\
& $-0.2 \pm 1.1$ & This study \\
\hline
\end{tabular}

Although our $\mathrm{N}_{2} \mathrm{O}$ sea-air fluxes are relatively close to previous studies (Table 2), our $\mathrm{CH}_{4}$ fluxes are much lower than those measured on Eurasian shelves, in $\mathrm{CH}_{4}$ "hotspots", and in polynya waters (Table 3). There are several reasons for this. Instead of taking the instantaneous ship wind speed, as is often done for air-sea flux calculations, we used a weighted mean over the 60 days prior to sampling. This approach incorporated variability in wind-speed, and thus produces piston velocity estimates that are more reflective of the average conditions experienced over the time of mixed layer ventilation. The more recent wind speeds are more heavily weighted, causing the wind speeds within the 7 days prior to sampling to have the most influence on the piston velocity $\left(\mathrm{k}_{\mathrm{w}}\right)$. These derived weighted piston velocities are often lower than those based on instantaneous or daily mean wind speed data. Indeed, we obtained significantly higher (by up to 190\%) sea-air fluxes when using mean daily wind speeds. An additional explanation for our lower derived $\mathrm{CH}_{4}$ seaair fluxes relates to the strong spatial variability in $\mathrm{CH}_{4}$ concentrations. Unlike many 
previous studies, we did not specifically sample any areas considered "hotspots" for $\mathrm{CH}_{4}$, so our estimates should be considered a conservative background level. Understanding the significance of $\mathrm{CH}_{4}$ hotspots to Arctic Ocean $\mathrm{CH}_{4}$ fluxes requires careful sampling that avoids statistical bias in the over-representation of either high or low $\mathrm{CH}_{4}$ waters. Carefully designed sampling programs, coupled with an objective analysis will provide a better perspective on the spatial distribution of these "hotspots", as well as a more complete picture of the overall distribution of $\mathrm{CH}_{4}$ concentrations.

Although sampling biases and different calculation approaches may explain the somewhat lower sea-air fluxes we observed relative to previous studies, there are also several hydrographic properties that would act to limit sea-air gas exchange. In general, low sea-air fluxes of $\mathrm{CH}_{4}$ and $\mathrm{N}_{2} \mathrm{O}$ can be attributed to the dilution of surface gas concentrations by melt-water, as previously suggested by Kitidis et al. [2010]. Indeed, fresh water contained low surface concentrations of both gases (Figure 2, Figure 3), resulting in low $\mathrm{CH}_{4}$ and $\mathrm{N}_{2} \mathrm{O}$ fluxes in the upper layer that exchanges with the atmosphere (Table 2, Table 3). As we did not have measurements within the mixed layer for stations that were partially covered with sea-ice, we did not calculate fluxes for these locations.

Table 3: Sea-air flux of $\mathrm{CH}_{4}$

\begin{tabular}{lll}
\hline Region & Sea-air flux $\left(\mu \mathrm{mol} \mathrm{CH} \mathrm{m}^{-2} \mathrm{~d}^{-1}\right)$ & Reference \\
\hline Bering Sea & $0.2 \pm 0.4$ & This study \\
Eastern Chukchi Sea & $1.9 \pm 1.4$ & This study \\
Western Chukchi Sea & $5-57$ & [Savvichev et al., 2007] \\
$\begin{array}{l}\text { Eastern Siberian Arctic (area- } \\
\text { weighted mean flux, summer) }\end{array}$ & $\sim 7-17$ & [Shakhova and Semiletov, 2007] \\
$\begin{array}{l}\text { East-Siberian Arctic Sea }\left(\mathrm{CH}_{4}\right. \\
\text { hotspots, summer) }\end{array}$ & $45-95$ & [Shakhova and Semiletov, 2007] \\
Barents Sea & $\sim 5$ & [Lammers et al., 1995] \\
Canada Basin & $1.3 \pm 1.1$ & This study \\
CAA & $1.2 \pm 1.1$ & This study \\
Davis Strait & $\sim 1.6$ & [Punshon et al., 2014] \\
Storfjorden polynya & $26-104$ & [Damm et al., 2007] \\
\hline
\end{tabular}

Based on the average sea-air flux for each sub-region and its area (Table 4), we calculated the annual emission of $\mathrm{CH}_{4}$ and $\mathrm{N}_{2} \mathrm{O}$ for the entire study region. We estimated 
an annual flux of $\mathrm{CH}_{4}$ on the order of $0.014 \pm 0.013 \mathrm{Tg} \mathrm{CH}_{4} \mathrm{yr}^{-1}$, equating to approximately $0.14 \%$ of the yearly global oceanic $\mathrm{CH}_{4}$ emissions, which are thought to be $\sim 10{\mathrm{Tg} \mathrm{yr}^{-1}}^{-1}$ [Reeburgh, 2007]. This is a conservative estimate, as it does not take into account $\mathrm{CH}_{4}$ accumulation under sea ice and subsequent release after sea ice break up, storm events (that increase the depth of the mixed layer), or "hotspots" that may be significant local sources of $\mathrm{CH}_{4}$. It is important to note that the Eastern Siberian Seas have been estimated to emit $1-8 \mathrm{Tg} \mathrm{CH}_{4} \mathrm{yr}^{-1}$ alone [Shakhova et al., 2005, 2010a], so our sea-air fluxes represent a minimum for the Arctic Ocean. We found that the North American Arctic Ocean was a minor sink of $\mathrm{N}_{2} \mathrm{O}$, with an integrated sea air flux on the order of $\sim-0.01 \pm 0.023 \mathrm{Tg} \mathrm{N} \mathrm{yr}^{-1}$. This low balance can be attributed to freshwater input in the summer which creates a low dissolved gas layer at the surface of the Arctic Ocean [Macdonald et al., 2004]. Our Chukchi Sea flux is much lower than previous estimates by Hirota et al. [2009], who determined the flux in the entire Chukchi Sea to be $\sim 0.07 \mathrm{Tg} \mathrm{N} \mathrm{yr}^{-1}$ (Table 2). However, this previous calculation was based on much fewer measurements, of which the majority were in the western region. Thus, we consider our estimate to be more representative for the eastern Chukchi Sea.

Table 4: Regional annual fluxes of $\mathrm{CH}_{4}$ and $\mathrm{N}_{2} \mathrm{O}$

\begin{tabular}{|c|c|c|c|c|}
\hline Region & $\begin{array}{l}\text { Mean sea-air flux } \\
\left(\mu \mathrm{mol} \mathrm{m}{ }^{-2} \mathrm{~d}^{-1}\right)\end{array}$ & Area $\left(\mathrm{km}^{2}\right)$ & & Annual flux \\
\hline Northern Bering Sea & $\begin{array}{l}-0.5 \pm 0.5 \mathrm{~N}_{2} \mathrm{O} \\
0.2 \pm 0.4 \mathrm{CH}_{4}\end{array}$ & 320,000 & & $\begin{array}{l}-1.7 \pm 1.5 \mathrm{Gg} \mathrm{N} \\
0.3 \pm 0.7 \mathrm{Gg} \mathrm{CH}_{4}\end{array}$ \\
\hline Eastern Chukchi Sea & $\begin{array}{l}-0.4 \pm 0.7 \mathrm{~N}_{2} \mathrm{O} \\
1.9 \pm 1.4 \mathrm{CH}_{4}\end{array}$ & 210,000 & & $\begin{array}{l}-0.9 \pm 1.4 \mathrm{Gg} \mathrm{N} \\
2.3 \pm 1.7 \mathrm{Gg} \mathrm{CH}_{4}\end{array}$ \\
\hline Canada Basin & $\begin{array}{l}-0.9 \pm 1.4 \mathrm{~N}_{2} \mathrm{O} \\
1.3 \pm 1.1 \mathrm{CH}_{4}\end{array}$ & 700,000 & & $\begin{array}{l}-6.1 \pm 10.2 \mathrm{Gg} \mathrm{N} \\
5.5 \pm 4.6 \mathrm{Gg} \mathrm{CH}_{4}\end{array}$ \\
\hline \multirow[t]{2}{*}{ CAA } & $\begin{array}{l}-0.2 \pm 1.1 \mathrm{~N}_{2} \mathrm{O} \\
1.2 \pm 1.1 \mathrm{CH}_{4}\end{array}$ & 840,000 & & $\begin{array}{l}-0.9 \pm 9.6 \mathrm{Gg} \mathrm{N} \\
5.7 \pm 5.5 \mathrm{Gg} \mathrm{CH}_{4}\end{array}$ \\
\hline & & & Total flux: & $\begin{array}{l}-0.0097 \pm 0.023 \mathrm{Tg} \mathrm{N} \\
0.014 \pm 0.013 \mathrm{Tg} \mathrm{CH}_{4}\end{array}$ \\
\hline
\end{tabular}




\section{4}

\section{Conclusions}

\subsection{MAIN FINDINGS}

This study covers a larger sampling region than any previous depth-resolved study of either $\mathrm{CH}_{4}$ or $\mathrm{N}_{2} \mathrm{O}$ in the Arctic Ocean. This synoptic perspective enables a pan-arctic view of the distributions of these gases, and reveals several important patterns. The highest concentrations of both gases were measured in the bottom waters of the shallow Chukchi Sea, where active microbial metabolism under low $\mathrm{O}_{2}$ conditions leads to high rates of net $\mathrm{CH}_{4}$ and $\mathrm{N}_{2} \mathrm{O}$ production. The high $\mathrm{N}_{2} \mathrm{O}$ concentrations that result from the denitrification and nitrification in the sediments on the shelf, are transported through the Canada Basin until they are attenuated in the CAA. In contrast, the $\mathrm{CH}_{4}$ is rapidly oxidized in the water column so that the high $\mathrm{CH}_{4}$ signature has a much more limited spatial extent. Both large super-saturation and under-saturation of $\mathrm{CH}_{4}$ were measured, likely owing to the diversity and ephemerality of its sources, and the high capacity for $\mathrm{CH}_{4}$ consumption in oxygenated waters. Indeed, the heavy $\partial^{13} \mathrm{C}_{\mathrm{CH} 4}$ signatures of low $\mathrm{CH}_{4}$ concentrations were likely a result of consumption within the water column, indicating that this is a key sink of $\mathrm{CH}_{4}$. Conversely, sources of $\mathrm{CH}_{4}$ in the Arctic Ocean may result from sedimentary methanogenesis, decomposing permafrost, dissociating gas hydrates, migration from geologic gas deposits, river input, methanogenesis in sea ice, and in situ water column production. Additionally, sea ice formation and melting were important processes in the cycling of these climate-active gases. Convective overturning due to brine rejection stirred up the sediments, likely adding $\mathrm{CH}_{4}$ and $\mathrm{N}_{2} \mathrm{O}$ to the water column where seafloor production of these gases is high. Production within sea ice was also likely a source, and may have caused the super-saturation of $\mathrm{CH}_{4}$ areas where sea ice was only partially melted. Although we measured elevated concentrations of both of $\mathrm{CH}_{4}$ and $\mathrm{N}_{2} \mathrm{O}$ in the water 
column, sea-air fluxes of these gases were relatively low compared to previous studies in the Arctic Ocean [e.g., Hirota et al., 2009; Shakhova et al., 2010]. The freshwater layer at the surface acted to dilute the concentrations of the gases within the mixed layer, limiting the associated sea-air fluxes.

This study adds a major new set of observations to the currently limited data set of Arctic Ocean $\mathrm{CH}_{4}$ and $\mathrm{N}_{2} \mathrm{O}$, with the first depth profiles of $\mathrm{CH}_{4}$ in the Canada Basin and Canadian Arctic Archipelago (CAA), and $\mathrm{N}_{2} \mathrm{O}$ depth profiles in the Beaufort Sea and much of the CAA. Our large-scale data set, combined with other hydrographic and oceanographic measurements, allowed us to examine likely processes driving the cycling of $\mathrm{CH}_{4}$ and $\mathrm{N}_{2} \mathrm{O}$ in the North American Arctic Ocean. We show that the Pacific Winter Water mass (PWW) is characterized by the highest $\mathrm{N}_{2} \mathrm{O}$ concentrations in the North American Arctic, and this signature persists as far east as the CAA. We also examined the importance of permafrost in relation to the water column concentrations of $\mathrm{CH}_{4}$ by comparing the sea-air fluxes in the Eastern Siberian Arctic Sea with those from the permafrost-free Chukchi Sea. We studied the role of sea ice in the biogeochemical cycling of $\mathrm{CH}_{4}$ and $\mathrm{N}_{2} \mathrm{O}$. We documented the subsurface $\mathrm{CH}_{4}$ maximum in the Canada Basin as well as the surface super-saturation, but under-saturation at depth at stations partially covered with sea-ice in the CAA.

A major contribution of this thesis is the provision of baseline $\mathrm{CH}_{4}$ and $\mathrm{N}_{2} \mathrm{O}$ concentration data for the Arctic. These baseline data will provide a benchmark for comparison against future studies as the Arctic environment undergoes rapid changes. Based on the results we obtained, we are able to speculate on how $\mathrm{CH}_{4}$ and $\mathrm{N}_{2} \mathrm{O}$ accumulation in Arctic waters may be influenced by climate-driven environmental change. The outcome will mainly depend on changes in carbon export and organic matter availability in shallow sediments, the reduction of the sea ice barrier to air-sea exchange, and the stability of shallow gas hydrate deposits on continental shelves.

\subsection{CAVEATS AND LIMITATIONS}

As this study was conducted on three separate cruises in different regions of the North American Arctic, we did not obtain the same resolution in all areas. The Beaufort Sea and CAA did not have the same density of stations as the northern Bering Sea and Chukchi Sea, 
limiting the conclusions we could draw from these regions. We also did not have as many $\partial^{13} \mathrm{C}_{\mathrm{CH} 4}$ isotope samples in the Canada Basin and Beaufort Sea or the CAA as we did in the Bering and Chukchi Seas, so we were unable to determine the $\mathrm{CH}_{4}$ sources east of the Chukchi Sea. As we only conducted sampling during the summer, our temporal resolution is also limited and we are unable to resolve seasonal changes in $\mathrm{CH}_{4}$ and $\mathrm{N}_{2} \mathrm{O}$ concentrations.

\subsection{FUTURE OUTLOOK}

This study reveals interesting new questions to guide future research. Additional $\mathrm{CH}_{4}$ studies should focus characterizing $\mathrm{CH}_{4}$ distributions in areas with subsea permafrost. The Beaufort Sea and Banks Island are the only regions in the North American Arctic Ocean with significant subsea permafrost deposits [Ruppel, 2015]. However, the Beaufort Sea has not been analyzed for $\mathrm{CH}_{4}$ in any comprehensive study since the early 1990's [Macdonald, 1976; Kvenvolden et al., 1993], and no measurements have been made in the vicinity of Banks Island. Additional samples for isotopic analysis, particularly ${ }^{14} \mathrm{C}$, would also be especially useful to differentiate between $\mathrm{CH}_{4}$ sourced from the methanogenesis of recent carbon, or $\mathrm{CH}_{4}$ derived from old carbon sources such as degrading permafrost and gas hydrates. Future studies should also investigate the source of the ubiquitous subsurface maximum in the Canada Basin. This feature is unusual because of the low primary productivity, yet higher $\mathrm{CH}_{4}$ concentrations than typically observed in open ocean subsurface maxima ( 3-5 nmol/L) [Reeburgh, 2007]. Potential processes leading to this sub-surface maximum could be investigated using stable isotopes $\left(\partial^{13} \mathrm{C}_{\mathrm{CH} 4}\right.$ and $\left.\partial \mathrm{D}_{\mathrm{CH} 4}\right), \mathrm{CH}_{4}$ production rate measurements, and DMSP-addition experiments.

Future $\mathrm{N}_{2} \mathrm{O}$ research should focus on following the PWW as it transits through the northern CAA. It remains unclear whether the $\mathrm{N}_{2} \mathrm{O}$ from the maximum is ventilated to the atmosphere or is diluted by river input and meltwater. Sampling with high spatial resolution in the northern archipelago may elucidate the specific processes that cause the decrease in $\mathrm{N}_{2}$ Oconcentrations as the water moves eastward. Additionally, $\mathrm{N}_{2} \mathrm{O}$ studies should focus on the Eurasian shelves. $\mathrm{N}_{2} \mathrm{O}$ distributions have not been studied outside of the North American Arctic Ocean, although the low oxygen concentrations and decomposing permafrost on these marginal shelves may produce significant quantities of 
$\mathrm{N}_{2} \mathrm{O}$. Finally, the relationship between sea-ice cycling and $\mathrm{CH}_{4} / \mathrm{N}_{2} \mathrm{O}$ dynamics is still poorly understood. In our study, fresh water acted to limit sea-air flux (due to dilution of gas concentrations), while we observed high gas concentrations in the surface water under marginal sea-ice conditions. It remains unclear what happens to the gas distribution as seaice breaks up in the spring and re-forms in the fall. High temporal resolution sampling (depth profiles, sea ice, and brine) during these critical times could provide an explanation for the high super-saturation observed under sea ice, relative to the underlying water column. It may also help us understand the sources of $\mathrm{CH}_{4}$ and $\mathrm{N}_{2} \mathrm{O}$ to the water column, and the seasonal variability in their sea-air flux. Such time-series work could be conducted at a number of field stations, including the soon to be completed Canadian High Arctic Research Stations (CHARS), located in Cambridge Bay, Nunavut. 


\section{References}

Aagaard, K., and E. C. Carmack (1989), The role of sea ice and other fresh water in the Arctic circulation, J. Geophys. Res., 94(1), 14,414-14,498, doi:10.1029/JC094iC10p14485.

Aagaard, K., L. K. Coachman, and E. Carmack (1981), On the halocline of the Arctic Ocean, Deep Sea Res. Part A, Oceanogr. Res. Pap., 28(6), 529-545, doi:10.1016/01980149(81)90115-1.

de Angelis, M. A., and C. Lee (1994), Methane production during zooplankton grazing on marine phytoplankton, Limnol. Ocean., 39(6), 1298-1308.

Archer, D. (2007), Methane hydrate stability and anthropogenic climate change, Biogeosciences Discuss., 4(2), 993-1057, doi:10.5194/bgd-4-993-2007.

Archer, D., B. Buffett, and V. Brovkin (2009), Ocean methane hydrates as a slow tipping point in the global carbon cycle., Proc. Natl. Acad. Sci. U. S. A., 106(49), 2059620601, doi:10.1073/pnas.0800885105.

Arrigo, K. R., and G. L. van Dijken (2011), Secular trends in Arctic Ocean net primary production, J. Geophys. Res., 116(C9), 1-15, doi:10.1029/2011JC007151.

Arrigo, K. R., and G. L. van Dijken (2015), Continued increases in Arctic Ocean primary production, Prog. Oceanogr., 136, 60-70, doi:10.1016/j.pocean.2015.05.002.

Bange, H. W. (2008), Gaseous Nitrogen Compounds (NO, N2O, N2, NH3) in the Ocean, in Nitrogen in the Marine Environment, edited by D. Capone, D. A. Bronk, M. R. Mulholland, and E. J. Carpenter, pp. 51-94.

Bange, H. W., R. Ramesh, S. Rapsomanikis, and M. O. Andreae (1998), Methane in surface waters of the Arabian Sea, Geophys. Res. Lett., 25(19), 3547-3550, doi:10.1029/98GL02710.

Brown, Z. W., K. L. Casciotti, R. S. Pickart, J. H. Swift, and K. R. Arrigo (2015), Aspects of the marine nitrogen cycle of the Chukchi Sea shelf and Canada Basin, Deep. Res. Part II Top. Stud. Oceanogr., 118, 73-87, doi:10.1016/j.dsr2.2015.02.009.

Brüchert, V., B. Currie, and K. R. Peard (2009), Hydrogen sulphide and methane emissions on the central Namibian shelf, Prog. Oceanogr., 83(1-4), 169-179, doi:10.1016/j.pocean.2009.07.017.

Burlin, Y. K., and Y. V. Shipel'kevich (2006), Principal features of the tectonic evolution of sedimentary basins in the western Chukchi shelf and their petroleum resource potential, Geotectonics, 40(2), 135-149, doi:10.1134/S0016852106020051.

Capelle, D. W., and P. D. Tortell (2016), Factors controlling methane and nitrous-oxide variability in the southern British Columbia coastal upwelling system, Mar. Chem., 179, 56-67, doi:10.1016/j.marchem.2016.01.011.

Capelle, D. W., J. W. Dacey, and P. D. Tortell (2015), An automated, high through-put method for accurate and precise measurements of dissolved nitrous-oxide and 
methane concentrations in natural waters, Limnol. Oceanogr. Methods, 13(7), 345355, doi:10.1002/lom3.10029.

Carmack, E. (2000), The Arctic Ocean's Freshwater Budget: Sources, Storage and Export, in The Freshwater Budget of the Arctic Ocean, vol. 70, edited by E. L. Lewis, E. P. Jones, P. Lemke, T. D. Prowse, and P. Wadhams, pp. 91-126, Kluwer Academic Publishers.

Carmack, E., and P. Wassmann (2006), Food webs and physical-biological coupling on pan-Arctic shelves: Unifying concepts and comprehensive perspectives, Prog. Oceanogr., 71, 446-477, doi:10.1016/j.pocean.2006.10.004.

Carmack, E., D. Barber, J. Christensen, R. Macdonald, B. Rudels, and E. Sakshaug (2006), Climate variability and physical forcing of the food webs and the carbon budget on panarctic shelves, Prog. Oceanogr., 71(2-4), 145-181, doi:10.1016/j.pocean.2006.10.005.

Chang, B. X., and A. H. Devol (2009), Seasonal and spatial patterns of sedimentary denitrification rates in the Chukchi Sea, Deep. Res. Part II Top. Stud. Oceanogr., 56(17), 1339-1350, doi:10.1016/j.dsr2.2008.10.024.

Codispoti, L. A., T. Yoshinari, and A. H. Devol (2005), Suboxic respiration in the oceanic water column, in Respiration in Aquatic Ecosystems, edited by P. A. del Giorgio and P. J. le B. Williams, pp. 225-247, Oxford University Press.

Codispoti, L. A., C. N. Flagg, and J. H. Swift (2009), Hydrographic conditions during the 2004 SBI process experiments, Deep. Res. Part II Top. Stud. Oceanogr., 56(17), 11441163, doi:10.1016/j.dsr2.2008.10.013.

Coffin, R. B., J. P. Smith, R. E. Plummer, B. Yoza, R. K. Larsen, L. C. Millholland, and M. T. Montgomery (2013), Spatial variation in shallow sediment methane sources and cycling on the Alaskan Beaufort Sea Shelf/Slope, Mar. Pet. Geol., 45, 186-197, doi:10.1016/j.marpetgeo.2013.05.002.

Coleman, D. D., J. B. Risatti, and M. Schoell (1981), Fractionation of carbon and hydrogen isotopes by methane oxidizing bacteria, Geochim. Cosmochim. Acta, 45, 1033-1037.

Cooper, L. W., J. W. McClelland, R. M. Holmes, P. A. Raymond, J. J. Gibson, C. K. Guay, and B. J. Peterson (2008), Flow-weighted values of runoff tracers (d18O, DOC, Ba, alkalinity) from the six largest Arctic rivers, Geophys. Res. Lett., 35(18), L18606, doi:10.1029/2008GL035007.

Dallimore, S. R. (1999), Regional gas hydrate occurrence, permafrost conditions, and Cenozoic geology, Mackenzie Delta area.

Damm, E., A. Mackensen, G. Budéus, E. Faber, and C. Hanfland (2005), Pathways of methane in seawater: Plume spreading in an Arctic shelf environment (SWSpitsbergen), Cont. Shelf Res., 25(12-13), 1453-1472, doi:10.1016/j.csr.2005.03.003.

Damm, E., U. Schauer, B. Rudels, and C. Haas (2007), Excess of bottom-released methane in an Arctic shelf sea polynya in winter, Cont. Shelf Res., 27(12), 1692-1701, doi:10.1016/j.csr.2007.02.003. 
Damm, E., R. P. Kiene, J. Schwarz, E. Falck, and G. Dieckmann (2008), Methane cycling in Arctic shelf water and its relationship with phytoplankton biomass and DMSP, Mar. Chem., 109(1-2), 45-59, doi:10.1016/j.marchem.2007.12.003.

Damm, E., E. Helmke, S. Thoms, and U. Schauer (2010), Methane production in aerobic oligotrophic surface water in the central Arctic Ocean, Biogeosciences, 7, 1099-1108, doi:www.biogeosciences.net/7/1099/2010/.

Damm, E., B. Rudels, U. Schauer, S. Mau, and G. Dieckmann (2015a), Methane excess in Arctic surface water- triggered by sea ice formation and melting., Sci. Rep., 5, 16179, doi:10.1038/srep16179.

Damm, E., S. Thoms, A. Beszczynska-Möller, E. M. Nöthig, and G. Kattner (2015b), Methane excess production in oxygen-rich polar water and a model of cellular conditions for this paradox, Polar Sci., 9(3), 327-334, doi:10.1016/j.polar.2015.05.001.

Darnis, G. et al. (2012), Current state and trends in Canadian Arctic marine ecosystems: II. Heterotrophic food web, pelagic-benthic coupling, and biodiversity, Clim. Change, 115(1), 179-205, doi:10.1007/s10584-012-0483-8.

Devol, A. H., L. A. Codispoti, and J. P. Christensen (1997), Summer and winter denitrification rates in western Arctic shelf sediments, Cont. Shelf Res., 17(9), 10291050, doi:10.1016/S0278-4343(97)00003-4.

Dickens, G. R., J. R. O’Neil, D. K. Rea, and R. M. Owen (1995), Dissociation of oceanic methane hydrate as a cause of the carbon isotope excursion at the end of the Paleocene, Paleoceanography, 10(6), 965-971, doi:10.1029/95PA02087.

Dickens, G. R., M. M. Castillo, and J. C. G. Walker (1997), A blast of gas in the latest Paleocene: Simulating first-order effects of massive dissociation of oceanic methane hydrate, Geology, 25(3), 259-262, doi:10.1130/00917613(1997)025<0259:ABOGIT>2.3.CO.

Elberling, B., H. H. Christiansen, and B. U. Hansen (2010), High nitrous oxide production from thawing permafrost, Nat. Geosci., 3(7), 506-506, doi:10.1038/ngeo893.

Farías, L., C. Fernández, J. Faúndez, M. Cornejo, and M. E. Alcaman (2009), Chemolithoautotrophic production mediating the cycling of the greenhouses gases $\mathrm{N} 2 \mathrm{O}$ and CH4 in an upwelling ecosystem, Biogeosciences Discuss., 6(3), 6205-6247, doi:10.5194/bgd-6-6205-2009.

Flückiger, J., A. Dällenbach, T. Blunier, B. Stauffer, T. F. Stocker, D. Raynaud, and J.-M. Barnola (1999), Variations in atmospheric N2O concentration during abrupt climatic changes, Science (80-. )., 285(5425), 227-230, doi:10.1126/science.285.5425.227.

Frame, C. H., E. Deal, C. D. Nevison, and K. L. Casciotti (2014), N2O production in the eastern South Atlantic: Analysis of $\mathrm{N} 2 \mathrm{O}$ stable isotopic and concentration data, Global Biogeochem. Cycles, 28(11), 1262-1278, doi:10.1002/2013GB004790.

Gagné, C. (2015), Dynamique de l'oxyde nitreux dans les eaux du détroit de Lancaster et du nord de la Baie de Baffin, Université Laval. 
Gong, D., and R. S. Pickart (2015), Summertime circulation in the eastern Chukchi Sea, Deep. Res. Part II Top. Stud. Oceanogr., 118, 18-31, doi:10.1016/j.dsr2.2015.02.006.

Granger, J., M. G. Prokopenko, D. M. Sigman, C. W. Mordy, Z. M. Morse, L. V. Morales, R. N. Sambrotto, and B. Plessen (2011), Coupled nitrification-denitrification in sediment of the eastern Bering Sea shelf leads to $15 \mathrm{~N}$ enrichment of fixed $\mathrm{N}$ in shelf waters, J. Geophys. Res. Ocean., 116(11), 1-18, doi:10.1029/2010JC006751.

Grantz, A., and P. E. Hart (2012), Petroleum prospectivity of the Canada Basin, Arctic Ocean, Mar. Pet. Geol., 30, 126-143, doi:10.1016/j.marpetgeo.2011.11.001.

Grebmeier, J. M. (1993), Studies of pelagic-benthic coupling extended onto the Soviet continental shelf in the northern Bering and Chukchi seas, Cont. Shelf Res., 13(5/6), 653-668, doi:10.1016/0278-4343(93)90098-I.

Grebmeier, J. M. (2012), Shifting Patterns of Life in the Pacific Arctic and Sub-Arctic Seas, Ann. Rev. Mar. Sci., 4, 63-78, doi:10.1146/annurev-marine-120710-100926.

Grebmeier, J. M., L. W. Cooper, H. M. Feder, and B. I. Sirenko (2006), Ecosystem dynamics of the Pacific-influenced Northern Bering and Chukchi Seas in the Amerasian Arctic, Prog. Oceanogr., 71, 331-361, doi:10.1016/j.pocean.2006.10.001.

Gruber, N., and J. L. Sarmiento (1997), Global patterns of marine nitrogen fixation and denitrification, Global Biogeochem. Cycles, 11(2), 235-266, doi:10.1029/97GB00077.

Grundle, D. S., R. Maranger, and S. K. Juniper (2012), Upper water column nitrous oxide distributions in the Northeast Subarctic Pacific Ocean, Atmosphere-Ocean, 50(4), 475-486, doi:10.1080/07055900.2012.727779.

Hameedi, M. J. (1978), Aspects of Water Column Primary Productivity in the Chukchi Sea During Summer, Mar. Biol., 48(1), 37-46, doi:10.1007/BF00390529.

He, X., L. Sun, Z. Xie, W. Huang, N. Long, Z. Li, and G. Xing (2013), Sea ice in the Arctic Ocean: Role of shielding and consumption of methane, Atmos. Environ., 67, 8-13, doi:10.1016/j.atmosenv.2012.10.029.

Heeschen, K. U., R. W. Collier, M. A. de Angelis, E. Suess, G. Rehder, P. Linke, and G. P. Klinkhammer (2005), Methane sources, distributions, and fluxes from cold vent sites at Hydrate Ridge, Cascadia Margin, Global Biogeochem. Cycles, 19(2), 1-19, doi:10.1029/2004GB002266.

Hirota, A., A. Ijiri, D. D. Komatsu, S. B. Ohkubo, F. Nakagawa, and U. Tsunogai (2009), Enrichment of nitrous oxide in the water columns in the area of the Bering and Chukchi Seas, Mar. Chem., 116(1-4), 47-53, doi:10.1016/j.marchem.2009.09.001.

Holmes, E. M., F. J. Sansone, T. M. Rust, and B. N. Popp (2000), Methane production, consumption, and air-sea exchange in the open ocean: An evaluation based on carbon isotopic ratios, Global Biogeochem. Cycles, 14(1), 1-10, doi:10.1029/1999GB001209.

Horak, R. E. A., H. Whitney, D. H. Shull, C. W. Mordy, and A. H. Devol (2013), The role of sediments on the Bering Sea shelf N cycle: Insights from measurements of benthic denitrification and benthic DIN fluxes, Deep. Res. Part II Top. Stud. Oceanogr., 94, 95-105, doi:10.1016/j.dsr2.2013.03.014. 
Hovland, M., A. G. Judd, and R. A. Burke (1993), The global flux of methane from shallow submarine sediments, Chemosphere, 26(1-4), 559-578, doi:10.1016/0045-

6535(93)90442-8.

IPCC (2013), Climate Change 2013: The Physical Science Basis. Contribution of Working Group I to the Fifth Assessment Report of the Intergovernmental Panel on Climate Change, edited by T. F. Stocker, D. Qin, G.-K. Plattner, M. Tignor, S. K. Allen, J. Boschung, A. Nauels, Y. Xia, V. Bex, and P. M. Midgley, Cambridge University Press.

James, R. H. et al. (2016), Effects of climate change on methane emissions from seafloor sediments in the Arctic Ocean: A review, Limnol. Oceanogr., in press, doi:10.1002/lno.10307.

Jones, E. P. (2003), Tracing Pacific water in the North Atlantic Ocean, J. Geophys. Res., 108(C4), 3116, doi:10.1029/2001JC001141.

Jones, E. P., and L. G. Anderson (1986), On the origin of the chemical properties of the Arctic Ocean halocline, J. Geophys. Res., 91(6), 10759, doi:10.1029/JC091iC09p10759.

Karl, D. M., and B. D. Tilbrook (1994), Production and transport of methane in oceanic particulate organic matter, Nature, 368(6473), 732-734, doi:10.1038/368732a0.

Karl, D. M., L. Beversdorf, K. M. Björkman, M. J. Church, A. Martinez, and E. F. Delong (2008), Aerobic production of methane in the sea, Nat. Geosci., 1(7), 473-478, doi:10.1038/ngeo234.

Kessler, J. D., W. S. Reeburgh, and S. C. Tyler (2006), Controls on methane concentration and stable isotope $(\delta 2 \mathrm{H}-\mathrm{CH} 4$ and $\delta 13 \mathrm{C}-\mathrm{CH} 4)$ distributions in the water columns of the Black Sea and Cariaco Basin, Global Biogeochem. Cycles, 20(4), 1-13, doi:10.1029/2005GB002571.

Kiene, R. P., L. J. Linn, and J. A. Bruton (2000), New and important roles for DMSP in marine microbial communities, J. Sea Res., 43(3-4), 209-224, doi:10.1016/S13851101(00)00023-X.

Kitidis, V., R. C. Upstill-Goddard, and L. G. Anderson (2010), Methane and nitrous oxide in surface water along the North-West Passage, Arctic Ocean, Mar. Chem., 121(1-4), 80-86, doi:10.1016/j.marchem.2010.03.006.

Kosmach, D. A., V. I. Sergienko, O. V. Dudarev, A. V. Kurilenko, O. Gustafsson, I. P. Semiletov, and N. E. Shakhova (2015), Methane in the surface waters of Northern Eurasian marginal seas, Dokl. Chem., 465(2), 281-285, doi:10.1134/S0012500815120022.

Kvenvolden, K. A. (1993), Gas Hydrates - Geological Perspective and Global Change, Rev. Geophys., 31(2), 173-187, doi:10.1029/93rg00268.

Kvenvolden, K. A., M. D. Lilley, T. D. Lorenson, P. W. Barnes, and E. Mclaughlin (1993), The Beaufort Sea continental shelf as a seasonal source of atmospheric methane, Geophys. Res. Lett., 20(22), 2459-2462, doi:10.1029/93GL02727.

Lamarque, J. F., J. T. Kiehl, C. A. Shields, B. A. Boville, and D. E. Kinnison (2006), Modeling the response to changes in tropospheric methane concentration; 
Application to the Permian-Triassic boundary, Paleoceanography, 21(3), PA3006, doi:10.1029/2006PA001276.

Lammers, S., E. Suess, and M. Hovland (1995), A large methane plume east of Bear Island (Barents Sea): implications for the marine methane cycle, Geol. Rundschau, 84(1), 59-66, doi:10.1007/BF00192242.

Loose, B., L. Miller, S. Elliot, and T. Papakyriakou (2011), Sea Ice Biogeochemistry and Material Transport Across the Frozen Interface, Oceanography, 24(3), 202-218, doi:10.5670/oceanog.2011.72.

Lowry, K. E., R. S. Pickart, M. M. Mills, Z. W. Brown, G. L. van Dijken, N. R. Bates, and K. R. Arrigo (2015), The influence of winter water on phytoplankton blooms in the Chukchi Sea, Deep. Res. Part II Top. Stud. Oceanogr., 118, 53-72, doi:10.1016/j.dsr2.2015.06.006.

Macdonald, R. W. (1976), Distribution of low-weight hydrocarbons in the southern Beaufort Sea, Environ. Sci. Technol., 10(13), 1241-1246.

Macdonald, R. W., E. Sakshaug, and R. Stein (2004), The Arctic Ocean: Modern Status and Recent Climate Change, in The Organic Carbon Cycle in the Arctic Ocean, edited by R. Stein and R. W. Macdonald, pp. 6-21, Springer.

Maslanik, J., J. Stroeve, C. Fowler, and W. Emery (2011), Distribution and trends in Arctic sea ice age through spring 2011, Geophys. Res. Lett., 38(13), L13502, doi:10.1029/2011GL047735.

McLaughlin, F., E. C. Carmack, R. W. Macdonald, A. J. Weaver, and J. Smith (2002), The Canada Basin, 1989-1995: Upstream events and far-field effects of the Barents Sea, J. Geophys. Res., 107(C7), 3082, doi:10.1029/2001JC000904.

McLaughlin, F. A., E. C. Carmack, R. G. Ingram, W. J. Williams, and C. Michel (2004), Oceanography of the Northwest Passage, in The Sea Vol 14: The Global Coastal Ocean, Interdisciplinary Regional Studies and Syntheses, vol. 14, edited by F. A. McLaughlin, E. C. Carmack, R. G. Ingram, W. J. Williams, and C. Michel, pp. 12111242, Harvard University Press.

McLaughlin, F. a., E. Carmack, A. Proshutinsky, R. A. Krishfield, C. Guay, J. M. Yamamoto-Kawai, M., Jackson, and B. Williams (2011), The Rapid Response of the Canada Basin to Climate Forcing, Oceanography, 24(3), 162-173, doi:10.5670/oceanog.2011.65.

Michel, C., R. G. Ingram, and L. R. Harris (2006), Variability in oceanographic and ecological processes in the Canadian Arctic Archipelago, Prog. Oceanogr., 71(2-4), 379-401, doi:10.1016/j.pocean.2006.09.006.

Millero, F. J., R. Feistel, D. G. Wright, and T. J. McDougall (2008), The composition of Standard Seawater and the definition of the Reference-Composition Salinity Scale, Deep Sea Res. Part I Oceanogr. Res. Pap., 55(1), 50-72, doi:10.1016/j.dsr.2007.10.001.

Naidu, A. S., L. W. Cooper, J. M. Grebmeier, T. E. Whitledge, and M. J. Hameedi (2004), The continental margin of the north Bering-Chukchi Sea: Concentrations, sources, fluxes, accumulation and burial rates of organic carbon, in The Organic Carbon Cycle 
in the Arctic Ocean, edited by R. Stein and R. W. Macdonald, pp. 193-203, Springer.

Naqvi, S. W. A., T. Yoshinari, D. . A. Jayakumar, M. A. Altabet, P. V. Narvekar, A. H.

Devol, and L. A. Codispoti (1998), Budgetary and biogeochemical implications of $\mathrm{N} 2 \mathrm{O}$ isotope signatures in the Arabian Sea, Nature, 394, 462-464, doi:10.1038/28828.

Naqvi, S. W. A., H. Naik, D. A. Jayakumar, M. S. Shailaja, and P. V. Narvekar (2006), Seasonal Oxygen Deficiency Over the Western Continental Shelf of India, NATO Sci. Ser., 64, 247-256, doi:10.1007/1-4020-4297-3.

Naqvi, S. W. A., H. W. Bange, L. FarÃ-As, P. M. S. Monteiro, M. I. Scranton, and J. Zhang (2010), Marine hypoxia/anoxia as a source of CH 4 and N 2O, Biogeosciences, 7(7), 2159-2190, doi:10.5194/bg-7-2159-2010.

Nevison, C., J. H. Butler, and J. W. Elkins (2003), Global distribution of N2O and the $\Delta \mathrm{N} 2 \mathrm{O}-\mathrm{AOU}$ yield in the subsurface ocean, Global Biogeochem. Cycles, 17(4), 1119, doi:10.1029/2003GB002068.

Nevison, C. D., R. F. Weiss, and D. J. Erickson (1995), Global Oceanic Emissions of Nitrous-Oxide, J. Geophys. Res., 100(C8), 15809-15820, doi:10.1029/95JC00684.

Nevison, C. D., T. J. Lueker, and R. F. Weiss (2004), Quantifying the nitrous oxide source from coastal upwelling, Global Biogeochem. Cycles, 18(1), GB1018, doi:10.1029/2003GB002110.

Nightingale, D., G. Malin, C. S. Law, J. Watson, S. Liss, and I. Liddicoat (2000), In situ evaluation of air-sea gas echange parameterizations using novel conservative and volatile tracers, Global Biogeochem. Cycles, 14(1), 373-387.

Oremland, R. S. (1979), Methanogenic activity in plankton samples and fish intestines: A mechanism for in situ methanogenesis in oceanic surface waters, Limnol. Oceanogr., 24(6), 1136-1141, doi:10.4319/lo.1979.24.6.1136.

Overduin, P. P., S. Liebner, C. Knoblauch, F. Gunther, S. Wetterich, L. Schirrmeister, H.W. Hubberten, and M. N. Grigoriev (2015), Methane oxidation following submarine permafrost degradation: measurements from a central Laptev Sea shelf borehole, $J$. Geophys. Res. Biogeosciences, 120(2), 965-978, doi:10.1002/2014JG002808.Received.

Parsons, T. R., Y. Maita, and C. M. Lalli (1984), A Manual of Chemical and Biological Methods for Seawater Analysis, Pergamon Press.

Pastick, N. J., M. Rigge, B. K. Wylie, M. T. Jorgenson, J. R. Rose, K. D. Johnson, and L. Ji (2014), Distribution and landscape controls of organic layer thickness and carbon within the Alaskan Yukon River Basin, Geoderma, 230-231, 79-94, doi:10.1016/j.geoderma.2014.04.008.

Paull, C. K., W. Ussler, S. R. Dallimore, S. M. Blasco, T. D. Lorenson, H. Melling, B. E. Medioli, F. M. Nixon, and F. A. McLaughlin (2007), Origin of pingo-like features on the Beaufort Sea shelf and their possible relationship to decomposing methane gas hydrates, Geophys. Res. Lett., 34(1), doi:10.1029/2006GL027977.

Paull, C. K. et al. (2011), Tracking the Decomposition of Submarine Permafrost and Gas Hydrate Under the Shelf and Slope of the Beaufort Sea, J. Chem. Inf. Model., 53(May 
2016), 160, doi:10.1017/CBO9781107415324.004.

Phrampus, B. J., M. J. Hornbach, C. Ruppel, and P. E. Hart (2014), Widespread gas hydrate instability on the upper U.S. Beaufort margin, J. Geophys. Res. Solid Earth, 119, 8594-8609, doi:10.1002/2014JB011290.Received.

Pickart, R. S., G. W. K. Moore, C. Mao, F. Bahr, C. Nobre, and T. J. Weingartner (2016), Circulation of Winter Water on the Chukchi Shelf in Early Summer,

Punshon, S., K. Azetsu-Scott, and C. M. Lee (2014), On the distribution of dissolved methane in Davis Strait, North Atlantic Ocean, Mar. Chem., 161, 20-25, doi:10.1016/j.marchem.2014.02.004.

Randall, K., M. Scarratt, M. Levasseur, S. Michaud, H. Xie, and M. Gosselin (2012), First measurements of nitrous oxide in Arctic sea ice, J. Geophys. Res. Ocean., 117(5), 2-9, doi:10.1029/2011JC007340.

Raynaud, D., and J. Chappellaz (1993), The record of atmospheric methane, in Atmospheric Methane: Sources, sinks, and role in global change, vol. 113, edited by M. A. K. Khalil, pp. 38-61, Springer-Verlag.

Redfield, A. C. (1942), The processes determining the concentration of oxygen, phosphate and other organic derivatives within the depths of the Atlantic ocean, Phys.

Oceanogr. Meteorol., 9(308), 5-21, doi:10.1575/1912/1053.

Reeburgh, W. (2007), Oceanic methane biogeochemistry, Am. Chem. Soc., 107(2), 486513, doi: $10.1021 / \mathrm{cr} 050362 \mathrm{v}$.

Reuer, M. K., B. A. Barnett, M. L. Bender, P. G. Falkowski, and M. B. Hendricks (2007), New estimates of Southern Ocean biological production rates from O2/Ar ratios and the triple isotope composition of O2, Deep. Res. Part I Oceanogr. Res. Pap., 54(6), 951-974, doi:10.1016/j.dsr.2007.02.007.

Rhee, T. S., A. J. Kettle, and M. O. Andreae (2009), Methane and nitrous oxide emissions from the ocean: A reassessment using basin-wide observations in the Atlantic, $J$. Geophys. Res. Atmos., 114(12), doi:10.1029/2008JD011662.

Ruppel, C. (2015), Permafrost-associated gas hydrate: Is it really approximately $1 \%$ of the global system?, J. Chem. Eng. Data, 60(2), 429-436, doi:10.1021/je500770m.

Ruppel, C. D. (2011), Methane hydrates and contemporary climate change, Nat. Educ. Knowl., 3(10), 29.

Rysgaard, S., R. N. Glud, N. Risgaard-Petersen, and T. Dalsgaard (2004), Denitrification and anammox activity in Arctic marine sediments, Limnol. Oceanogr., 49(5), 14931502, doi:10.4319/lo.2004.49.5.1493.

Rysgaard, S., R. N. Glud, M. K. Sejr, M. E. Blicher, and H. J. Stahl (2008), Denitrification activity and oxygen dynamics in Arctic sea ice, Polar Biol., 31(5), 527-537, doi:10.1007/s00300-007-0384-x.

Sakshaug, E. (2004), Primary and secondary production in the Arctic Seas, in The Organic Carbon Cycle in the Arctic Ocean, edited by R. Stein and R. W. Macdonald, pp. 5781 , Springer. 
Sasakawa, M., U. Tsunogai, S. Kameyama, F. Nakagawa, Y. Nojiri, and A. Tsuda (2008), Carbon isotopic characterization for the origin of excess methane in subsurface seawater, J. Geophys. Res. Ocean., 113(3), 1-7, doi:10.1029/2007JC004217.

Savvichev, a S., I. I. Rusanov, N. V Pimenov, E. E. Zakharova, E. F. Veslopolova, a I. Lein, K. Crane, and M. V Ivanov (2007), Microbial processes of the carbon and sulfur cycles in the Chukchi Sea, Mikrobiologiia, 76(5), 682-693, doi:10.1134/S0026261707050141.

Schilt, A., M. Baumgartner, T. Blunier, J. Schwander, R. Spahni, H. Fischer, and T. F. Stocker (2010), Glacial-interglacial and millennial-scale variations in the atmospheric nitrous oxide concentration during the last 800,000 years, Quat. Sci. Rev., 29(1-2), 182-192, doi:10.1016/j.quascirev.2009.03.011.

Schlosser, P., B. Kromer, B. Ekwurzel, G. Bönisch, A. McNichol, R. Schneider, K. von Reden, H. G. Östlund, and J. H. Swift (1997), The first trans-Arctic 14C section: comparison of the mean ages of the deep waters in the Eurasian and Canadian basins of the Arctic Ocean, Nucl. Instruments Methods Phys. Res. Sect. B Beam Interact. with Mater. Atoms, 123(1-4), 431-437, doi:10.1016/S0168-583X(96)006775 .

Shakhova, N., and I. Semiletov (2007), Methane release and coastal environment in the East Siberian Arctic shelf, J. Mar. Syst., 66(1-4), 227-243, doi:10.1016/j.jmarsys.2006.06.006.

Shakhova, N., I. Semiletov, and G. Panteleev (2005), The distribution of methane on the Siberian Arctic shelves: Implications for the marine methane cycle, Geophys. Res. Lett., 32(9), L09601, doi:10.1029/2005GL022751.

Shakhova, N., I. Semiletov, A. Salyuk, V. Yusupov, D. Kosmach, and O. Gustafsson (2010a), Extensive methane venting to the atmosphere from sediments of the East Siberian Arctic Shelf., Science, 327(5970), 1246-1250, doi:10.1126/science.1182221.

Shakhova, N., I. Semiletov, I. Leifer, A. Salyuk, P. Rekant, and D. Kosmach (2010b), Geochemical and geophysical evidence of methane release over the East Siberian Arctic Shelf, J. Geophys. Res. Ocean., 115(8), C08007, doi:10.1029/2009JC005602.

Shakhova, N. et al. (2013), Ebullition and storm-induced methane release from the East Siberian Arctic Shelf, Nat. Geosci., 7(January), 64-70, doi:10.1038/ngeo2007.

Shakhova, N. et al. (2015), The East Siberian Arctic Shelf: towards further assessment of permafrost-related methane fluxes and role of sea ice., Philos. Trans. A. Math. Phys. Eng. Sci., 373(2052), 20140451-, doi:10.1098/rsta.2014.0451.

Shimada, K., E. C. Carmack, K. Hatakeyama, and T. Takizawa (2001), Varieties of shallow temperature maximum waters in the Western Canadian Basin of the Arctic Ocean, Geophys. Res. Lett., 28(18), 3441-3444, doi:10.1029/2001GL013168.

Smith, R. E. H., J. Anning, P. Clement, and G. Cota (1988), Abundance and production of ice algae in Resolute Passage, Canadian Arctic, Mar. Ecol. Ser., 48, 251-263, doi:10.3354/meps048251.

Springer, A. M., and C. P. McRoy (1993), The paradox of pelagic food webs in the 
northern Bering S e a o HI . Patterns of primary production, Cont. Shelf Res., 13(5), 575-599, doi:10.1016/0278-4343(93)90095-f.

Striegl, R. G., M. M. Dornblaser, C. P. McDonald, J. R. Rover, and E. G. Stets (2012), Carbon dioxide and methane emissions from the Yukon River system, Global Biogeochem. Cycles, 26(4), doi:10.1029/2012GB004306.

Tanaka, T., L. Guo, C. Deal, N. Tanaka, T. Whitledge, and A. Murata (2004), N deficiency in a well-oxygenated cold bottom water over the Bering Sea shelf: Influence of sedimentary denitrification, Cont. Shelf Res., 24(12), 1271-1283, doi:10.1016/j.csr.2004.04.004.

Timmermans, M. L., C. Garrett, and E. Carmack (2003), The thermohaline structure and evolution of the deep waters in the Canada Basin, Arctic Ocean, Deep. Res. Part I Oceanogr. Res. Pap., 50(10-11), 1305-1321, doi:10.1016/S0967-0637(03)00125-0.

Ward, B. B. (2008), Nitrification in Marine Systems.

Weaver, J.S., Stewart, J. M. (1982), In situ hydrates under the Beaufort Sea shelf, 4th Can. Permafr. Conf., 312-319.

Weingartner, T., K. Aagaard, R. Woodgate, S. Danielson, Y. Sasaki, and D. Cavalieri (2005), Circulation on the north central Chukchi Sea shelf, Deep Sea Res. Part II Top. Stud. Oceanogr., 52(24-26), 3150-3174, doi:10.1016/j.dsr2.2005.10.015.

Weiss, R. F., and B. A. Price (1980), Nitrous oxide solubility in water and seawater, Mar. Chem., 8(4), 347-359, doi:10.1016/0304-4203(80)90024-9.

Welch, H. E., M. A. Bergmann, T. D. Siferd, K. A. Martin, M. F. Curtis, and R. E. Crawford (1992), Energy Flow through the Marine Ecosystem of the Lancaster Sound Region, Arctic Canada, Arctic, 45(4), 343-357, doi:10.14430/arctic1413.

Whiticar, M. J. (1999), Carbon and hydrogen isotope systematics of bacterial formation and oxidation of methane, Chem. Geol., 161(1-3), 291-314, doi:10.1016/S00092541(99)00092-3.

Whiticar, M. J., and E. Faber (1986), Methane oxidation in sediment and water column environments-Isotope evidence, Org. Geochem., 10(4-6), 759-768, doi:10.1016/S0146-6380(86)80013-4.

Wiesenburg, D. A., and N. L. Guinasso Jr. (1979), Equilibrium solubilities of methane, carbon monoxide, and hydrogen in water and sea water, J. Chem. Eng. Data, 24(4), 356-360, doi:10.1021/je60083a006.

Woodgate, R. A., K. Aagaard, and T. J. Weingartner (2005a), A year in the physical oceanography of the Chukchi Sea: Moored measurements from autumn 1990-1991, Deep. Res. Part II Top. Stud. Oceanogr., 52(24-26), 3116-3149, doi:10.1016/j.dsr2.2005.10.016.

Woodgate, R. A., K. Aagaard, and T. J. Weingartner (2005b), Monthly temperature, salinity, and transport variability of the Bering Strait through flow, Geophys. Res. Lett., 32(4), 1-4, doi:10.1029/2004GL021880.

Yamagishi, H., N. Yoshida, S. Toyoda, B. N. Popp, M. B. Westley, and S. Watanabe (2005), 
Contributions of denitrification and mixing on the distribution of nitrous oxide in the North Pacific, Geophys. Res. Lett., 32(4), 1-4, doi:10.1029/2004GL021458.

Yamamoto-Kawai, M., E. Carmack, and F. McLaughlin (2006), Nitrogen balance and Arctic throughflow., Nature, 443(7107), 43, doi:10.1038/443043a.

Yoshida, N., H. Morimoto, M. Hirano, I. Koike, S. Matsuo, E. Wada, T. Saino, and A. Hattori (1989), Nitrification rates and $15 \mathrm{~N}$ abundances of N2O and NO3- in the western North Pacific, Nature, 342, 895-897, doi:10.1038/342895a0.

Zhan, L., L. Chen, J. Zhang, and Y. Li (2015), A vertical gradient of nitrous oxide below the subsurface of the Canada Basin and its formation mechanisms, J. Geophys. Res. Ocean., 2401-2411, doi:10.1002/2014JC010337.Received.

Zhang, J., L. Zhan, L. Chen, Y. Li, and J. Chen (2015), Coexistence of nitrous oxide undersaturation and oversaturation in the surface and subsurface of the western Arctic Ocean, J. Geophys. Res. Ocean., 120(12), 8392-8401, doi:10.1002/2015JC011245. 